\title{
Modification of a Human DNA Extraction Protocol to Mitigate Operator Risk when Analyzing Human DNA Evidence Contaminated with Risk Group 3 Bacteria
}

\author{
By \\ Christine C. Hause

\begin{abstract}
A thesis submitted to
the Facility of Graduate Studies and Research

in partial fulfilment of the requirements for the degree of Master of Science

Department of Biology

Carleton University

Ottawa, Ontario
\end{abstract}

(C) Copyright, 2007, Christine C. Hause 


$\begin{array}{ll}\begin{array}{l}\text { Library and } \\ \text { Archives Canada }\end{array} & \begin{array}{l}\text { Bibliothèque et } \\ \text { Archives Canada }\end{array} \\ \begin{array}{l}\text { Published Heritage } \\ \text { Branch }\end{array} & \begin{array}{l}\text { Direction du } \\ \text { Patrimoine de l'édition }\end{array} \\ \begin{array}{l}\text { 395 Wellington Street } \\ \text { Ottawa ON K1A ON4 }\end{array} & \begin{array}{l}\text { 395, rue Wellington } \\ \text { Ottawa ON K1A ON4 } \\ \text { Canada }\end{array}\end{array}$

Your file Votre référence ISBN: 978-0-494-33700-4 Our file Notre référence ISBN: 978-0-494-33700-4

NOTICE:

The author has granted a nonexclusive license allowing Library and Archives Canada to reproduce, publish, archive, preserve, conserve, communicate to the public by telecommunication or on the Internet, loan, distribute and sell theses worldwide, for commercial or noncommercial purposes, in microform, paper, electronic and/or any other formats.

The author retains copyright ownership and moral rights in this thesis. Neither the thesis nor substantial extracts from it may be printed or otherwise reproduced without the author's permission.
AVIS:

L'auteur a accordé une licence non exclusive permettant à la Bibliothèque et Archives Canada de reproduire, publier, archiver, sauvegarder, conserver, transmettre au public par télécommunication ou par l'Internet, prêter, distribuer et vendre des thèses partout dans le monde, à des fins commerciales ou autres, sur support microforme, papier, électronique et/ou autres formats.

L'auteur conserve la propriété du droit d'auteur et des droits moraux qui protège cette thèse. $\mathrm{Ni}$ la thèse ni des extraits substantiels de celle-ci ne doivent être imprimés ou autrement reproduits sans son autorisation.
In compliance with the Canadian

Privacy Act some supporting forms may have been removed from this thesis.

While these forms may be included in the document page count, their removal does not represent any loss of content from the thesis.
Conformément à la loi canadienne sur la protection de la vie privée, quelques formulaires secondaires ont été enlevés de cette thèse.

Bien que ces formulaires aient inclus dans la pagination, il n'y aura aucun contenu manquant.

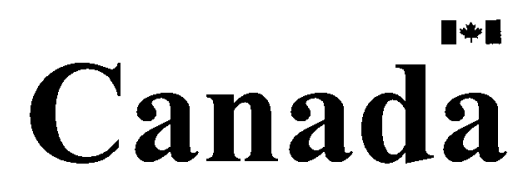




\begin{abstract}
The intentional release of a biothreat agent is a crime. In such an event, forensic scientists would be called upon to analyse DNA evidence to identify the perpetrators. Contamination of this evidence with the biothreat agent places forensic scientists at risk. The purpose of this research was to modify a DNA extraction procedure to accomplish two goals; render the human DNA evidence safe for analysis, and, maintain the integrity of the human DNA. The approach was to introduce a filtration step. Human DNA samples contaminated with bacteria were extracted as per a procedure currently in use in forensic laboratories. The DNA extracts were filtered through $0.2 \mu \mathrm{m}$ filters and evaluated for survival of the contaminant, and the ability to successfully obtain a human DNA profile. The non-destructive modification yielded safe DNA extracts suitable for human profiling and for microbiological identification.
\end{abstract}




\section{ACKNOWLEDGEMENTS}

First, I'd like to thank Dr. Della Wilkinson for giving me the opportunity to work on such an exciting project. Thank you so much for your guidance and support throughout my project. The monthly meetings and updates were very helpful, especially while writing my thesis.

I would also like to thank Myron Smith for supervising my master's research project. I appreciate your advice and support throughout the many years, both during my graduate and undergraduate degree.

I would like to express my appreciation for all the time and effort that my lab supervisor Denis Laframboise gave in helping me with my research. I am grateful for your input and supervision; I valued all of your ideas and comments. Thank you so much, I have learned an incredible amount of knowledge from you.

I would also like to thank my committee members Paul Payette and George Carmody for your help and ideas during my committee meetings.

I would also wish to thank James Elliott of the RCMP for performing the forensic analysis on the samples and for providing technical assistance. Also, thanks to Chantal Frégeau and Ron Fourney of the RCMP for their input and expertise.

Many thanks to the OLS lab staff past and present for their support and friendship. Thanks for the many great lunches girls! Thank you James Peeke for providing me with the opportunity to work in such an amazing lab, I am truly grateful. Also, thank you to my second lab - the Smith Lab, especially Melissa Begin, thanks for all the great nerdy science talks! 
This research wouldn't have been possible without the funding from the RCMP, Public Health Agency of Canada, Carleton University and Ontario Graduate Scholarship.

To my family, thank you so much for your love and support throughout my many years of schooling. To my husband Chris, I can't thank you enough for helping me through this. I couldn't have done this project without your love and understanding. 


\section{TABLE OF CONTENTS}

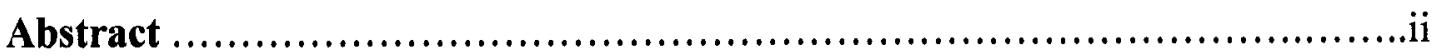

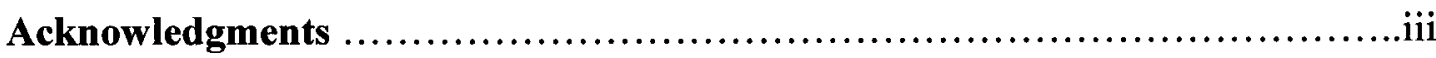

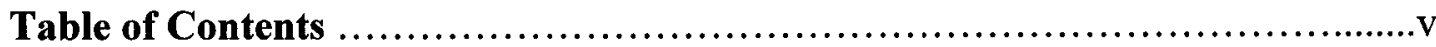

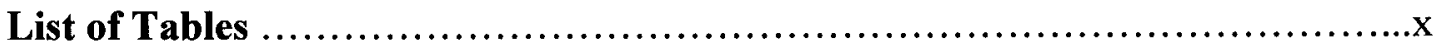

List of Figures ...................................................................

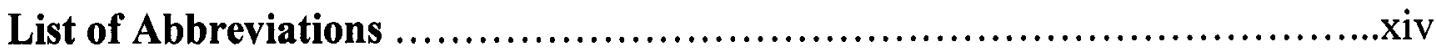

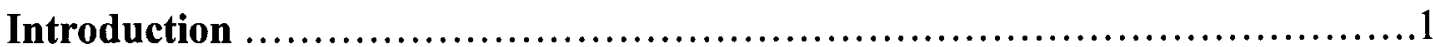

Bioterrorism and Biological Warfare .............................................

Bioterrorism....................................................................

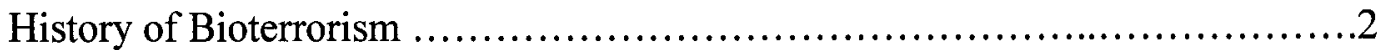

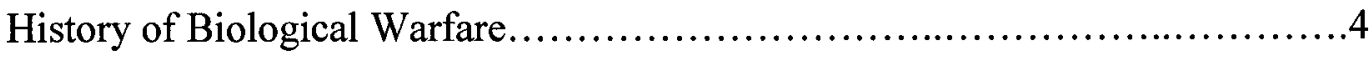

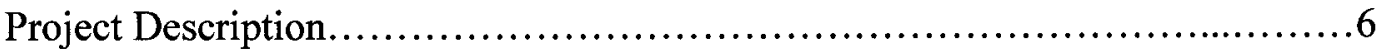

Bioterrorism Agents used in this study ........................................

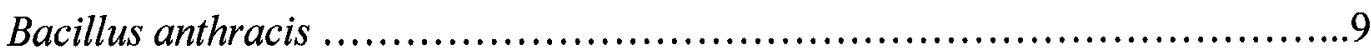

Francisella tularensis............................................................. 11

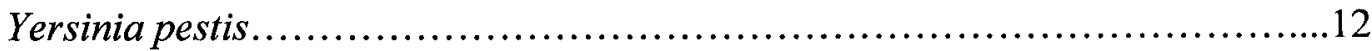

Methods of Sample Decontamination..........................................

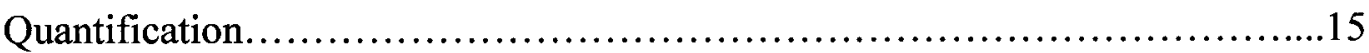

Short Tandem Repeats................................................... 17

Short Tandem Repeats used in this study ................................ 18

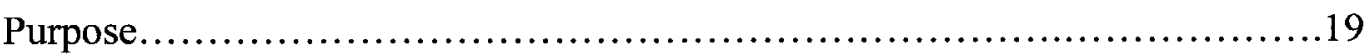

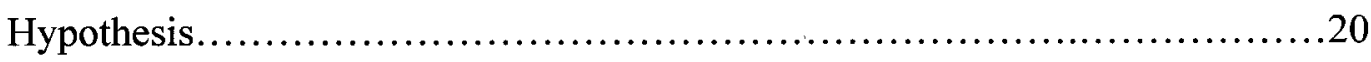




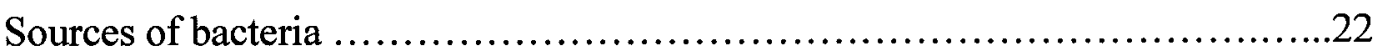

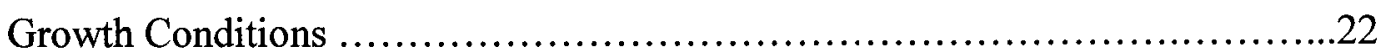

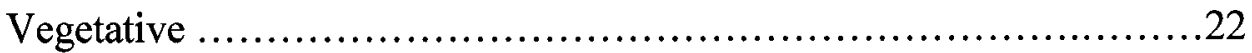

Spores ......................................................22

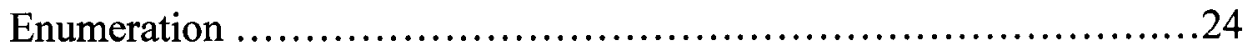

Containment Level 3 (CL3) Personal Protective Equipment (PPE) ..............24

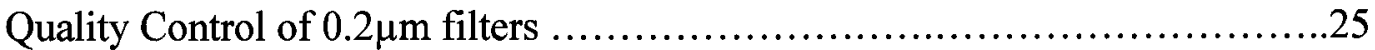

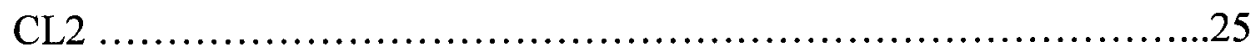

CL3 ..........................................................25

Biolog Bacterial Identification .........................................26

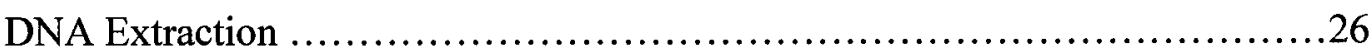

Sample Types................................................26

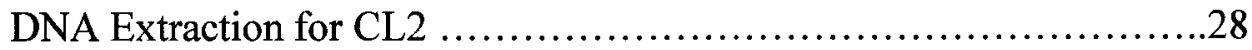

Final CL3 extraction procedure ................................29

Removing DNA extractions from CL3............................31

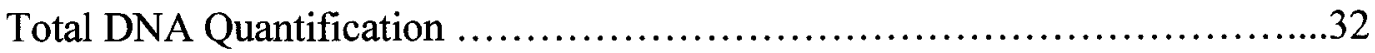

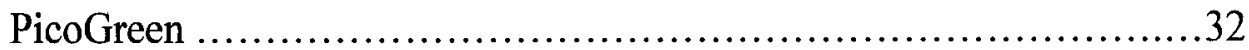

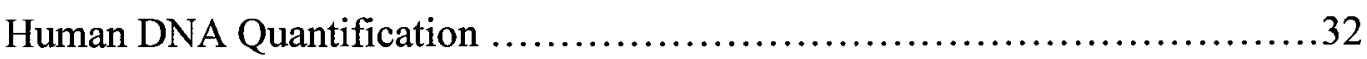

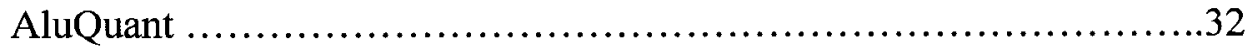

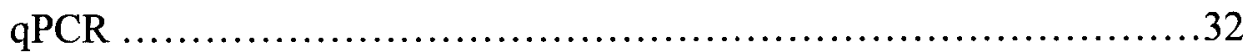

Gel Electrophoresis ................................................... 34

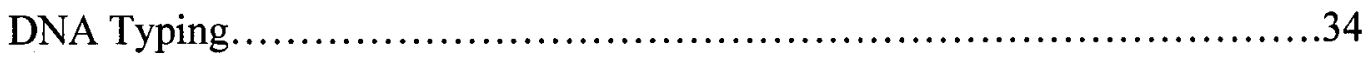

vi 
Biothreat Screening Kit .36

Results .37

Testing of Millipore $0.2 \mu \mathrm{m}$ filter. .37

Quality Assurance of $0.2 \mu \mathrm{m}$ filters with Risk Group 1 and 2 bacteria............38

Quality Assurance of $0.2 \mu \mathrm{m}$ filters with Risk Group 2 and 3 bacteria....

DNA Extraction from varying concentrations of blood contaminated with $S$. aureus:

DNA extraction of blood contaminated with $S$. aureus at $95^{\circ} \mathrm{C}$ for $30 \mathrm{~min}$ and $56^{\circ} \mathrm{C}$ overnight to be quantified and tested for DNA degradation .45

DNA Extraction and quantification of varying amounts of blood. .52

DNA Quantification by two Methods: Promega AluQuant and Molecular Probes PicoGreen. 54

Extraction, quantification and amplification of blood contaminated with risk group 1 and 2 vegetative bacteria

DNA Extraction, Quantification and Amplification of various types of samples from a crime scene.

Extraction, quantification and amplification of gum, hair and cigarettes contaminated with risk group 1 and 2 vegetative bacteria..... .66

Effect of filtration on DNA yield.

Extraction/Amplification/Quantification of blood filtered after lysis vs. after elution.

DNA Amplification and Quantification of human blood contaminated with risk group 3 bacteria. .74

Biothreat Screening....................................................8 80

DNA Typing............................................................. 84

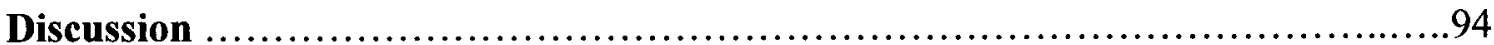

Research Objectives - Quality Control for Safety............................96

vii 
Research Objectives - Quality Control for DNA Integrity.....................98

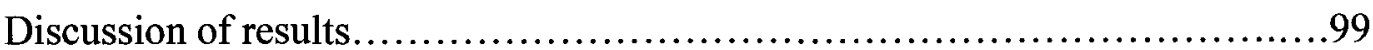

Effect of heat on bacteria..............................................99

Varying concentrations of blood quantified with PicoGreen..................101

Quantification of DNA after filtration using PicoGreen........................ 101

DNA Extraction and Quantification of varying amounts of blood with AluQuant........................................................... 102

Extraction, quantification and amplification of DNA from blood contaminated with S. aureus at $56^{\circ} \mathrm{C}$ overnight.................................

Extraction, quantification and amplification of blood contaminated

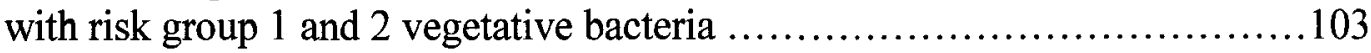

DNA Extraction, Quantification and Amplification of various sample types

Extraction, quantification and amplification of gum, hair and cigarettes contaminated with risk group 1 and 2 vegetative bacteria............. 105

Effect of filtration on DNA yield........................................ 105

Extraction/Amplification/Quantification of blood filtered after lysis vs. after elution.

DNA Amplification and Quantification of human blood contaminated with Risk Group 3 bacteria............................................ 106

Short Tandem Repeat Analysis............................................107

Biothreat Screening for Risk Group 3 bacteria................................ 109

Methods of Decontaminating Samples..................................110

Causes of DNA Degradation......................................... 111

DNA Quantification..................................................112

Bacterial Detection and Identification...................................... 114

Future Applications................................................116

viii 


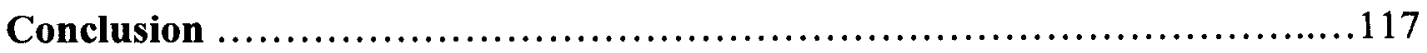

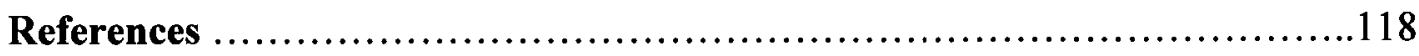




\section{LIST OF TABLES}

Table 1 List of bacterial organisms used in research project

Table 2 Short tandem repeat D18 and D3 primer information

Table 3 Experimental protocol for real time PCR using Roche LightCycler

FastStart MasterPlus SYBR Green I kit on the LightCycler

Table 4 Concentration of human and $S$. aureus DNA determined using

PicoGreen and Roche LightCycler fluorometer

Table 5 Crossing point values of DNA from blood contaminated with bacteria, amplified with primers for STR D18 and D3

Table 6 Concentration of human and $S$. aureus DNA determined using

PicoGreen and Roche LightCycler fluorometer

Table 7 Crossing point values of DNA from blood contaminated with bacteria that was lysed at $95^{\circ} \mathrm{C}$ for $30 \mathrm{~min}$ and amplified with primers for STR D18 and D3

Table 8 Crossing point values of DNA from blood contaminated with bacteria that was lysed at $56^{\circ} \mathrm{C}$ for $30 \mathrm{~min}$ and amplified with primers for STR D18 and D3

Table 9 Quantification of DNA from varying amounts of human blood extracted with Promega DNA IQ system and quantified using Promega AluQuant DNA Quantitation System

Table 10 Total amount of human DNA from blood contaminated with Staphylococcus aureus quantified using Promega AluQuant

Table 11 Total amount of DNA from blood contaminated with

Staphylococcus aureus quantified using PicoGreen

Table 12 Crossing point values of female and male human DNA

contaminated with $S$. aureus that were amplified using primers for short tandem repeats D18 and D3 in a multiplex reaction

Table 13 Quantification of DNA using Promega AluQuant on a luminometer, Roche LightCycler FastStart MasterPlus SYBR Green I kit and Quantifiler on an ABI Prism Sequence Detection System 
Table 14 Quantification of DNA using Promega AluQuant on a

luminometer, Roche LightCycler FastStart MasterPlus SYBR

Green I kit and Quantifiler on an ABI Prism Sequence Detection

System

Table 15 Quantification of DNA using Promega AluQuant on a

luminometer, Roche LightCycler FastStart MasterPlus SYBR

63

Green I kit and Quantifiler on an ABI Prism Sequence Detection System

Table 16 Table 16 - DNA Extracted from various sample types, quantified and amplified using Roche LightCycler.

Table 17 Total amount of human DNA (ng) from chewing gum contaminated with risk group 1 or 2 bacteria

Table 18 Total amount of human DNA from human hair roots contaminated with risk group 1 and risk group 2 bacteria

Table 19 Total amount of DNA in cigarette butts contaminated with risk group 1 and risk group 2 bacteria

Table 20 Total amount of DNA in epithelial cells from latex gloves

contaminated with risk group 1 and risk group 2 bacteria

Table 21 Comparison of filtration vs. no filtration of human blood DNA samples extracted with Promega DNA IQ kit

Table 22 Comparison of human DNA quantity from blood filtered after lysis or after elution.

Table 23 Quantification and amplification of STRs D18 and D3 from human blood samples contaminated with risk group 3 bacteria using quantitative real time PCR with Roche LightCycler FastStart DNA MasterPlus SYBR Green I. Trial 1.

Table 24 Quantification and amplification of STRs D18 and D3 from human blood samples contaminated with risk group 3 bacteria using quantitative real time PCR with Roche LightCycler FastStart DNA MasterPlus SYBR Green I. Trial 2.

Table 25 Quantification and amplification of STRs D18 and D3 from human blood samples contaminated with risk group 3 bacteria using quantitative real time PCR with Roche LightCycler FastStart DNA MasterPlus SYBR Green I. Trial 3 
Table 26 Testing of DNA from human blood contaminated with risk group 3 samples with a Biothreat Screening kit with the Roche LightCycler

Table 27 Ratio of STR D3/D18 Relative Fluorescent Units (RFU) to 90 determine DNA degradation for samples from blood contaminated with risk group 1 and 2 bacteria

Table 28 Ratio of STR D3/D18 Relative Fluorescent Units (RFU) to determine DNA degradation for samples from blood contaminated with risk group 1 and 2 bacteria

Table 29 Ratio of STR D3/D18 Relative Fluorescent Units (RFU) to determine DNA degradation for samples from gum, hair and cigarettes contaminated with risk group 1 and 2 bacteria

Table 30 Ratio of STR D3/D18 Relative Fluorescent Units (RFU) to determine DNA degradation for samples from blood contaminated with risk group 3 bacteria 


\section{LIST OF FIGURES}

Figure 1 Flow Chart: DNA extraction and analysis of human samples potentially contaminated with risk group 3 bacteria

Figure 2 Testing of Millipore $0.2 \mu \mathrm{m}$ Ultrafree ${ }^{\circledR}-\mathrm{MC}$ centrifugal filter with

$B$. subtilis spores and $S$. aureus vegetative bacteria

Figure 3 Testing of Millipore $0.2 \mu \mathrm{m}$ Ultrafree ${ }^{\circledR}-\mathrm{MC}$ centrifugal filter with risk group 1 and 2 bacteria

Figure 4 Testing of Millipore $0.2 \mu \mathrm{m}$ Ultrafree $\mathbb{B}-\mathrm{MC}$ centrifugal filter with risk group 2 and 3 bacteria

Figure 5 Gel electrophoresis of DNA from blood contaminated with $S$. aureus and amplified with primers for either STR D18 or D3.

Figure 6 Gel electrophoresis of DNA from blood contaminated with $S$. aureus and amplified with primers STR D18 and D3 in a multiplex reaction

Figure 7 DNA standard curve using human genomic DNA standard from Promega AluQuant kit

Figure 8 Example of an amplification curve using primers for STR D18 and D3 with Roche LightCycler FastStart MasterPlus SYBR Green I

Figure 9 Electropherogram STR profiles of DNA from Female Subject's blood contaminated with risk group 1 and risk group 2 bacteria

Figure 10 Electropherogram STR profiles of DNA from Male Subject's blood contaminated with risk group 1 and 2 bacteria

Figure 11 Electropherogram STR profiles of DNA from various sample types contaminated with risk group 1 and 2 bacteria

Figure 12 Electropherogram STR profiles of DNA from human blood contaminated with risk group 3 bacteria 


\section{LIST OF ABBREVIATIONS}

$\begin{array}{ll}\text { ATP } & \text { adenosine triphosphate } \\ \text { B } & \text { blood } \\ \text { BSC } & \text { biological safety cabinet } \\ \text { bp } & \text { base pair } \\ \text { C } & \text { cytosine } \\ \text { cfu } & \text { colony forming units } \\ \text { CL2 } & \text { containment level } 2 \\ \text { CL3 } & \text { containment level 3 } \\ \text { conc. } & \text { concentration } \\ \text { Cp } & \text { crossing point } \\ \text { DIUF } & \text { deionized ultra filtered } \\ \text { DNA } & \text { deoxyribonucleic acid } \\ \text { ds } & \text { double stranded } \\ \text { DTT } & \text { dithiothreitol } \\ \text { EDTA } & \text { ethylenediamine tetraacetic acid } \\ \text { EF } & \text { edema factor } \\ \text { ELISA } & \text { enzyme linked immunosorbent assay } \\ \text { EMS } & \text { emergency medical services } \\ \text { g } & \text { gravity } \\ \text { G } & \text { guanine } \\ \text { H } & \text { human DNA standard } \\ \text { HCl } & \text { hydrogen chloride } \\ \text { HEPA } & \text { high efficiency particulate air filter } \\ \text { HI } & \text { heat inactivated } \\ \text { INF } & \text { interferon } \\ \text { hr } & \text { hours } \\ \text { ID } & \text { identification } \\ \text { kg } & \text { kilogram } \\ \text { LF } & \text { lethal factor } \\ \text { MgCl } & \text { magnesium chloride } \\ \text { min } & \text { minutes } \\ \text { MLVA } & \text { multiple loci VNTR analysis } \\ \text { mm } & \text { millimetres } \\ \text { MnSO } & \text { manganese sulphate monohydrate } \\ \text { na } & \text { not applicable } \\ \text { NaCl } & \text { sodium chloride } \\ \text { neg } & \text { negative } \\ \text { ng } & \text { nanogram } \\ \text { NIST } & \text { National Institute of Standards and Technology } \\ \text { nm } & \text { nanometre } \\ \text { NR } & \text { no reaction } \\ \text { OLS } & \text { Office of Laboratory Security } \\ \text { O/N } & \text { overnight } \\ & \end{array}$




$\begin{array}{ll}\text { PA } & \text { protective antigen } \\ \text { PAPR } & \text { powered air purifying respirator } \\ \text { PBS } & \text { phosphate buffered saline } \\ \text { PCR } & \text { polymerase chain reaction } \\ \text { pg } & \text { picogram } \\ \text { PPE } & \text { personal protective equipment } \\ \text { ProK } & \text { proteinase K } \\ \text { PVDC } & \text { polyvinylidene chloride } \\ \text { RCMP } & \text { Royal Canadian Mounted Police } \\ \text { RG1 } & \text { risk group 1 } \\ \text { RG2 } & \text { risk group 2 } \\ \text { RG3 } & \text { risk group 3 } \\ \text { RNA } & \text { ribonucleic acid } \\ \text { rpm } & \text { rotations per minute } \\ \text { S } & \text { seconds } \\ \text { S } & \text { Staphylococcus aureus } \\ \text { SB } & \text { Staphylococcus aureus } \text { mixed with blood } \\ \text { SEB } & \text { stain extraction buffer } \\ \text { STD } & \text { standard } \\ \text { STR } & \text { short tandem repeat } \\ \text { TAE } & \text { Tris-Acetate-EDTA } \\ \text { TBE } & \text { Tris-Borate-EDTA } \\ \text { TNF } & \text { tumour necrosis factor } \\ \text { TSA } & \text { tryptic soy agar } \\ \text { TSB } & \text { tryptone soya broth } \\ \mu 1 & \text { microlitres } \\ \text { US } & \text { United States } \\ \text { UV } & \text { ultra violet } \\ \text { V } & \text { volts } \\ \text { VNTR } & \text { variable number tandem repeats } \\ & \end{array}$




\section{INTRODUCTION}

\section{Bioterrorism and Biological Warfare}

Bioterrorism and biological warfare may both have the same biological agents in common yet they have a very different purpose. The goal of bioterrorism isn't to cause a great number of mass causalities like biological warfare, it is to cause panic and disrupt the normal pattern of society. Bioterrorists try to make people anxious and constantly on guard. Even small scale events which only involve a small number of people or that have no casualties can still cause panic. Bioterrorism uses biological agents to get a message across which could be political, racial or economical and in order to restore order certain demands must be met. Bioterrorism is normally a quick event which is unpredictable and without warning (von Lubitz, 2004).

Biological weapons are produced from biological agents which are living organisms such as bacteria or viruses that infect humans, plants or animals. They could also include toxins produced from living organisms such as bacteria, plants or animals. Biological weapons can be released from a spraying device or an explosive device to aerosolize the biological agent so that it can spread and infect a large area. They are normally released from aircrafts or vehicles or from a high building (Hawley \& Eitzen, 2001).

\section{Bioterrorism}

Terrorists are using biological agents as opposed to chemical agents since smaller amounts of biological agent are needed compared to chemical to achieve the same effect (Sheeran, 2002). Biological agents are relatively easy to manufacture without highly 
sophisticated labs or expertise and they can be easily shipped without being detected. Once the agent is released it is difficult to detect and the effects normally take a couple of days to appear. Discovery of a biological event will likely take the form of people seeking medical attention. Epidemiological investigation will progress over a period of time to determine the agent involved, how the cases are related, and if a bioterrorist event has taken place. By this time the bioterrorist is long gone. Bioterrorism can have a large impact on society, both psychological and economical. People are afraid to go to large events or to use public transportation which are probable targets for bioterrorism. Also, every time there is a flu epidemic it has citizens wondering if it may be due to bioterrorism and many more people seek healthcare than normal.

Since the series of anthrax letters that appeared throughout the US postal service during the fall of 2001, more money has been spent on research and emergency preparedness for bioterrorism (von Lubitz, 2004). Panic arising from a bioterrorism event can lead to increased demands on, and even the collapse of, the health care system. But now due to recent bioterrorist attacks there has been a great improvement in our antibioterrorism capabilities including new effective training, rapid identification of organisms, immediate treatment, isolation and containment.

\section{History of Bioterrorism}

Incidents of bioterrorism have been occurring for as long as we can remember. Rye ergot was used to poison wells during the Sixth Century BC. Back in the middle ages people used to try to contaminate water supplies by tossing corpses of infected animals into wells or rivers. Others would catapult bodies infected with plague, like the Tartar army who infected their enemies during the siege of Kaffa in 1346 (Demetrius, 2002). 
Some used small pox contaminated clothing to give to their enemies like in the case of Pizzaro and the South American Indians in the $15^{\text {th }}$ century. In the 1700 s the English gave North American Indians blankets infected with smallpox during the war (von Lubitz, 2004).

In 1984 the Bhagwan Shree Rajneesh Cult in Oregon, US, used Salmonella typhimurium to contaminate a salad bar in order to eliminate the opposition in a local election (Kortepeter \& Parker, 1999). Threats and hoaxes can be just as effective as an actual bioterrorist attack. In 1989 the US Food and Drug Association had to perform a large investigation for contaminated fruit after a threat was received by Chilean workers. There has been increasing amounts of anthrax letter hoaxes and threats that are being used to increase the public's anxiety and cause panic (von Lubitz, 2004).

In 1990 Japanese members of the Aum Shinrikyo religious cult attempted to spray $B$. anthracis spores from the top of an eight story building. The attempt failed due to the type of anthrax they were using, it was found to be similar to the avirulent Sterne strain (Schmid \& Kaufmann, 2002). They also attempted to aerosolize anthrax and botulinum in Tokyo on several other occasions. In 1995 they were responsible for the sarin gas release in Tokyo's subway system (Henderson, 1999).

In September and October 2001, right after the September $11^{\text {th }}$ attack on the World Trade Centre, there was a bioterrorist attack using anthrax in the US. Media company employees and postal workers were infected with inhalational and cutaneous anthrax due to envelopes contaminated with $B$. anthracis spores (Dull et. al., 2002). Four envelops were discovered and the targets were NBC news anchor Tom Brokaw, the editor of the New York post, Senator Tom Daschle and Senator Patrick Leahy. There 
were a total of 22 people infected with anthrax, 11 inhalational and 11 cutaneous anthrax cases due to the handling of the envelopes or breathing in the bacterial spores. There were 5 deaths, all from inhalational anthrax. Many mail processing facilities were sampled and found to be positive for $B$. anthracis and had to be shut down. Clinical samples from patients and environmental samples taken from the four envelopes and from mail sorting machines from the various mail facilities all were found to be indistinguishable when tested by Multiple Loci VNTR Analysis (MLVA) for molecular typing (Jernigan et. al., 2002).

\section{History of Biological Warfare}

During the First World War it was believed that Germans used biological agents such as anthrax and glanders against the USA, France, Romania and Spain (Roffey et. al., 2002). It was suggested that they used infected livestock and transported them to Romania and France. It was also thought that the Germans attempted to spread plague and Cholera in countries such as Russia, Italy and Romania. In 1925 the Geneva Protocol came into effect which disallowed the use of chemical and bacterial warfare agents and was signed by 108 nations (von Lubitz, 2004). This protocol only banned the use of biological warfare agents but it did not ban the production or research of biological agents so countries still continued producing and storing them in case of an attack.

During the Second World War, Canada, USA, UK, Germany, Japan and the Soviet Union all were developing biowarfare programs. The Germans were accused of experimenting with biological agents with Russian prisoners. The Japanese were also accused of using biological agents against Chinese and Russian civilians and prisoners (Schmid \& Kaufmann, 2002). It was also believed that Japan used aircrafts to release $Y$. 
pestis infected fleas which started a plague epidemic in China and Manchuria (Demetrius, 2002). Japan was interested in studying anthrax, plague, typhoid, dysentery and cholera and these agents were mass produced and devices and bombs to release the agents were developed (Roffey et. al., 2002). Not all biological warfare programs concentrated on biological agents that would harm humans, Canada and Britain were looking at agents that would harm livestock and crop plants. The UK was interested in anthrax to harm cattle by using cattle cakes containing anthrax. The British contaminated Gruinard Island while experimenting with anthrax bombs (Roffey et. al., 2002). Canada, USA and UK were working together on a joint project that studied the spread of botulin, plague and anthrax although it never reached the production stage (Roffey et. al., 2002). The US started its own biowarfare program in 1941 in order to compete with Germany and Japan's programs. Approximately 3,500 people were involved in these projects and a large number of agents were investigated. Most of the research was performed at Fort Detrick in Maryland. The USA developed a way to aerosolize wet or dry pathogens using a small particle size aerosolizer. President Nixon stopped all biological warfare production in 1969 and only allowed biodefense research to continue (Roffey et. al., 2002).

In 1972 the Biological and Toxin Weapons Convention took place and was signed by 103 nations. This convention still allowed for defensive research to take place. The Soviet Union developed as many as 50 research facilities employing as many as 60,000 people to produced large quantities of biowarfare agents. The Soviet Intelligence was thought to have developed an explosive device which inserts biotoxin pellets into humans (von Lubitz, 2004). They had a large stockpile of smallpox virus and had developed 
bombs that would release the agent (Henderson, 1999). The Soviets were also studying plague, botulism and tetanus as well as methods of releasing the agent by aircraft. They established many anti-plague institutes throughout the country that were affiliated with laboratories in order to monitor and deal with outbreaks. An organization called Biopreparat was set up to develop new biological warfare technologies (Roffey et. al., 2002). In 1979 a research facility in Sverdlovsk had an accidental release that lead to many deaths from inhalational anthrax. At the time the Soviet Union stated that the deaths were due to the consumption of contaminated meat. In 1992 President Yeltsin decided to ban the production of biowarfare agents (Meselson et. al., 1994).

In 1995 it was revealed that Iraq had a major biological weapons capacity. It was known that they were developing anthrax as a weapon, but it was discovered that they possessed 8,000 litres of the spore suspension along with 20,000 litres of botulinum toxin as well as bombs that could release the spores or toxins. They also possessed airplanes that could aerosolize the biothreat agents (Henderson, 1999)

\section{Project Description}

Bioterrorism is a crime; therefore evidence must be collected and investigated in an attempt to identify the suspect(s). Samples from a bioterrorist event could be contaminated with risk group 3 (RG3) bacteria if found at the scene of the crime or the site of manufacturing. If there were an accidental release of RG3 agents it would still need to be investigated and samples collected. In addition forensic scientists are faced with the possibility that routine samples are contaminated with unknown high risk agents. Many RG3 bacteria are commonly found in the soil and could potentially be found in 
regular forensic samples. Therefore safe handling of samples is necessary for the safety of lab personnel.

The main goal of this research was to create a non-destructive method of rendering human DNA safe from contaminating RG3 bacteria while minimizing DNA degradation. Quality control for safety and for DNA integrity needs to be performed for samples before being sent to forensic labs for DNA typing. In order to ensure safety, all DNA samples should be checked for bacterial growth. Half of the DNA extract should be inoculated into the appropriate media and incubated for 2 weeks to ensure that the samples are safe. To check for DNA integrity a quick analysis of short tandem repeats can be performed. Primers for human short tandem repeats D18 and D3 can be used with quantitative real time PCR to make sure that sufficient DNA is present for DNA typing.

The bacterial agents being studied in this research project included risk group 1 bacteria: Bacillus subtilis, risk group 2 bacteria: Staphylococcus aureus, Pseudomonas aeruginosa, Bacillus anthracis Sterne strain and risk group 3 bacteria: Bacillus anthracis, Yersinia pestis and Francisella tularensis. RG1 and RG2 agents were first investigated in order to ensure that the methods worked and to become familiar with the methods before using a higher risk agent.

\section{Bioterrorism Agents used in this study}

Biological agents to be used for bioterrorism are categorized into different classes depending on their threat to the public according to the Centre for Disease Control. Class A agents are categorized based upon their ease of dissemination, person to person transmission, high mortality, serious social disruption and need for emergency preparedness measures. Category B agents are moderately easy to disseminate, cause 
moderate morbidity and lower mortality rates and they require an enhanced disease surveillance. Category $\mathrm{C}$ agents are emerging pathogens which have potential to be used as biothreat agents and could possibly be engineered to cause more damage. They are a threat due to their availability, ease of production and dissemination and they could possibly cause high morbidity and mortality (Centre for Disease Control and Prevention, 2007).

In Canada organisms are also classified into different risk groups according to their pathogenicity, infectious dose, mode of transmission, host range, availability of effective preventive measures and availability of treatment. Risk group 1 is the lowest with a low individual and community risk and risk group 4 is the highest with high individual and community risk (Public Health Agency of Canada, 2004).

Bacillus anthracis (Anthrax), Francisella tularensis (Tularemia) and Yersinia pestis (plague) are three types of bacteria that are classified as both Class A agents and risk group 3 agents. When working with these bacterial agents special precautions are taken and work must be done under high level containment. Laboratories are classified according to the type of personal protection equipment used and the type of containment that is needed. The risk group 3 bacterial agents used in this study should be handled in a Containment Level 3 (CL3) laboratory which requires a lab with primary and secondary barriers so that the infectious agent isn't released into the environment. Agents normally used in a CL3 laboratory are infectious through the airborne route and therefore respiratory protection such as powdered air purifying respirators are needed as well as HEPA (high efficiency particulate air) filtration of air being exhausted from the laboratory (Public Health Agency of Canada, 2004). 


\section{Bacillus anthracis}

Bacillus anthracis is the bacterium that causes anthrax. It is a gram positive, nonmotile, spore forming rod that is found in the soil. Anthrax typically infects herbivores or carnivores and can infect humans, although it is not spread from person to person (Smith et. al., 2000). There are three different methods of contracting anthrax: cutaneous, ingestion or inhalation. Cutaneous anthrax occurs when anthrax enters the skin after handling of animal hide or wool that is infected. Cutaneous anthrax has a mortality rate of 5 to $20 \%$ if it is not treated (Dang et. al., 2001). This type of anthrax is especially dangerous for textile workers who process wool or cashmere (Levi et. al., 2003). Within a few days of infection, a painless black scab appears followed by edema which can be cured with antibiotics (Turnbull, 1991).

Ingestion of contaminated meat can cause gastrointestinal anthrax with symptoms consisting of nausea, vomiting, fever and abdominal pain and can be lethal if untreated (Bell et. al., 2002). Anthrax that is contracted through inhalation of spores can have a mortality rate close to $100 \%$ if untreated (Dang et. al., 2001). Once spores are inhaled they are phagocytosed by alveoli macrophages where spores germinate and are transported to the regional lymph nodes and eventually into the blood stream (GuidiRontani \& Mock, 2002). For both gastrointestinal and inhalation anthrax symptoms are mild at first with low fever, mild diarrhea, vomiting or cramps and flu like symptoms. Symptoms can rapidly develop and can include sepsis, shock and respiratory failure (Turnbull, 1991).

Anthrax virulence is caused by virulence genes (dep, capACB, acpA) associated with its capsule which is encoded by the plasmid pXO2 and by three toxins encoded by 
the plasmid pXO1 (Pannucci et. al, 2002). The toxins include the edema factor (EF), the lethal factor (LF) and the protective antigen (PA). Strains of B. anthracis need both plasmids in order to be virulent (Collier \& Young, 2003).

When there are unfavourable conditions such as poor nutrients, the vegetative form of $B$. anthracis produces endospores through sporulation. Metabolism is slowed down and is eventually inactive and the cell becomes very structured. Once conditions become more favourable and there are available nutrients the spore enters into germination and is metabolically active again (Liu et. al., 2004). Anthrax spores can persist through various conditions such as heat, desiccation, $\mathrm{pH}$ and chemicals. Anthrax spores were isolated from brine inclusion found to be 250 million years old and were reported to survive in a bee within amber that was 25-40 million years old (Dang et. al., 2001).

With the exception of smallpox virus, anthrax is believed to be the greatest bioterrorist threat. Anthrax's potential as a biothreat agent stems from its high mortality rate, its ease of propagation and its resistance to environmental conditions, allowing it to be easily spread in the environment (Schmid \& Kaufmann, 2002). Anthrax spores are favourable due to their persistence in extreme conditions, virulence and the fact that it can be made into a powdered form which can be easily disseminated. A simple method that proved effective in 2001 was to disseminate anthrax spores in powdered form by mail. When the letters were opened anthrax spores were aerosolized infecting the recipient. Another method is to aerosolize the spores using a spraying device that would spray either dry or liquid anthrax over an area (Reshetin and Regens, 2003). It has been estimated that if $50 \mathrm{~kg}$ powdered anthrax is released by aircraft over a city of 500,000 
people, half of the exposed population could be killed and the anthrax could travel $20 \mathrm{~km}$ or more under ideal weather conditions (Whitby et. al., 2002). Anthrax is a great threat since it is endemic in many countries and is found in the soil, therefore it can be easily obtained and cultured. It is estimated that the infectious dose for inhalational anthrax is between 8000-10000 CFU (Schmid \& Kaufmann, 2002).

\section{Francisella tularensis}

Francisella. tularensis is a small, gram-negative, aerobic, non-motile coccobacillus that causes tularemia in humans. Tularemia is a zoonotic disease with common hosts which include rabbits, hares, ground squirrels, voles, water rats and muskrats. Ticks, biting fleas and mosquitoes are important vectors in the spread of this disease. Outbreaks in animal populations usually result in an outbreak in the human population as well (Ellis et al., 2002). F. tularensis has been classified into four subspecies: tularensis, holarctica, mediasiatica and novicida. The first three subspecies are infectious to humans and the most virulent of the subspecies is tularensis (type A). The subspecies holarctica (type B) was used to make an attenuated live vaccine strain for humans. Subspecies novicida is not infectious in humans but in mice it is just as virulent as tularensis and it serves as a very useful model for F. tularensis (Santic et. al., 2005).

The route of entry is through the skin, lungs, mucous membranes and gastrointestinal tract. The type of infection depends on the route of entry and the targeted organs are the lymph nodes, spleen, liver, kidney and lungs (Dennis et. al., 2001). F. tularensis as a bioterrorist agent would be aerosolized or would be contaminated in food or water. The typical incubation period varies between 3-5 days or even up to 14 days. The symptoms of tularemia include headache, fever, chills, sore throat, back pain, body 
aches. There may also be signs of pneumonia or nausea, diarrhea and vomiting (Kemp, 2001). There are six different forms of tularemia, all depending on the site of infection. They include typhoidal tularemia and septic tularemia which cause systemic inflammation and can have a mortality rate of 30-60\% (Ellis et. al., 2002). Pneumonic tularemia is caused by inhalation which would be problematic in case of bioterrorism due to its high rate of fatality. If water or food is contaminated with $F$. tularensis oropharyngeal tularemia can occur and could develop into tonsillitis. Both ulceroglandular and glandular tularemia are caused by insect bites, which produce a papule at the site of infection and ulcers (Kemp, 2001).

The reason $F$. tularensis is considered a potential biological weapon is due to the fact that it is highly infectious only requiring as little as 10 organisms to cause disease and can remain viable in a cold environment for weeks (Kemp, 2001). F. tularensis is dangerous due to its ease of production, ease of dissemination, high rates of morbidity and mortality and its difficulty in detecting and diagnosing (Dennis et. al., 2001; Firmani \& Broussard, 2003). Although F. tularensis grows rapidly in a host it does not grow well in a laboratory. Incubation can take between 2-4 days which is problematic when trying to detect the disease in patients (Ellis et. al., 2002).

\section{Yersinia pestis}

The plague pandemic has caused the deaths of over 200 million people worldwide. It has not yet been eradicated and there are still cases every year in the US and thousands around the world. Plague is a disease affecting humans that is caused by the bacterium Yersinia pestis. Two other members of the Yersinia genus include Yersinia enterocolitica and Yersinia pseudotuberculosis which cause food borne diseases in 
humans (Cornelis et. al., 1998). Y. pestis can take on two forms, depending on the route of entry; bubonic plague or pneumonic plague. Fleas feed upon rodents and if a rodent is infected the flea can pass the bacteria onto humans, which results in bubonic plague. Symptoms from bubonic plague consist of swollen lymph nodes or bubo in the armpit or groin area. Bubonic plague can lead to septicaemic plague if the bacteria enter the bloodstream or pneumonia if the bacteria become airborne. Pneumonic plague occurs when bacteria are passed on from person to person by coughing or close contact. When $Y$. pestis is inhaled it becomes very difficult to diagnose and treat since symptoms are delayed and there is a very short incubation time of only 1-3 days (Titball et. al., 2003). Symptoms can include fever, sore throat, chills, headache, shortness of breath, cough with bloody sputum, weakness and malaise which can be confused with many other sicknesses (von Lubitz, 2004). If a patient is left untreated, pneumonic plague is usually fatal after 24 hours (Whitby et. al., 2002).

When a flea, typically Xenopsylla cheopsis, feeds on rodents that are infected with $Y$. pestis, the bacteria promote aggregation, which then allows the flea to infect humans since the blood containing bacteria could not be digested (Titball et. al., 2003). Once inside the host $Y$. pestis is capable of surviving due to its ability to resist phagocystosis by macrophages and polymorphonuclear leukocytes. It is also able to defeat the host's nonspecific immune response by inhibition of respiratory burst, induction of apoptosis and inhibition of TNF- $\alpha$ and IFN- $\gamma$ release (Cornelis et. al., 1998).

$Y$. pestis is considered a potential biothreat agent since it can be easily spread from person to person by close contact through coughing and sneezing. The incubation time can range from 1-6 days so a person can be infected and not know it and can travel a 
large distance and spread the disease in a different location. Also, it is commonly found in nature, therefore it can be easily acquired and grown in the laboratory, although assembling a weapon to disperse the bacteria may be a bit tricky. It has been estimated by the World Health Organization that if $50 \mathrm{~kg}$ of $Y$. pestis was released over a city of 5 million there could be as many as 36000 deaths due to pneumonic plague and 150,000 people could become infected (Whitby et. al., 2002).

\section{Methods of Sample Decontamination}

There are various different methods of decontaminating forensic evidence. They include thermal, chemical, irradiation and physical decontamination. Thermal decontamination involves using heat inactivation by boiling the sample or autoclaving. Chemical inactivation could include using detergents, bleach, or vaporized hydrogen peroxide to decontaminate samples or buildings exposed to biothreat agents. Even the lysis buffer used in DNA extractions could be considered a means of inactivating contaminating vegetative bacteria. Electron beam irradiation has been used by the US Postal Service to sterilize mail since the bioterrorist attack in September 2001 when envelops containing anthrax were sent in the mail (Castle et. al., 2003). Physical methods include filtration or separation of contaminating material. These methods may all be capable of inactivating bacterial agents but it is important to investigate the effects that these methods have on the human DNA and whether or not a full DNA profile can be generated for forensic use. The method that will be proposed in this research is using a $0.2 \mu \mathrm{m}$ filter along with centrifugation to remove contaminating bacteria from DNA samples. DNA quantification will be used to ensure that enough template DNA is present for typing using short tandem repeats. 


\section{Quantification}

Before using short tandem repeats for DNA analysis, DNA samples should always be quantified. DNA quantification is important since the amount of DNA used is critical and should be within a range of $0.5-2.5 \mathrm{ng}$. If there is not enough DNA present there could be stochastic amplification which may lead to missing alleles and too much DNA could give off scale fluorescence or an increase in strand slippage or stutter effects (Kline et. al., 2005). Allele dropout from samples with a low copy number could be misleading since it may lead to homozygous typing when it should be heterozygous (Alonso et. al., 2004).

There are many different ways to quantify DNA and each method has its advantages and disadvantages. A very simple method is measuring DNA absorbance using a spectrophotometer at $260 \mathrm{~nm}$. An optical density of 1.0 corresponds to a concentration of $40 \mu \mathrm{g} / \mathrm{ml}$. For DNA purity a ratio for $260 / 280$ of $>1.8$ should indicate that the sample does not contain protein impurities. EDTA, Tris and other buffer components give background absorbance which could alter the results. Also, RNA and nucleotides present in the sample will increase the DNA concentration reading (Biochrom Ultrospec 2100 pro UV/Visible Spectrophotometer manual, 2002). PicoGreen (B) is a fluorescent dye that binds to double stranded DNA and with a spectrofluorometer it can be used to quantify DNA. DNA samples containing PicoGreen are excited at $480 \mathrm{~nm}$ and the emitted wavelength is measured at $520 \mathrm{~nm}$. It has a sensitivity range of $25 \mathrm{pg} / \mathrm{ml}-1000 \mathrm{ng} / \mathrm{ml}$ and the standard curve is linear even in the presence of salts, detergents and proteins contaminating DNA samples (Quant-iT ${ }^{\mathrm{TM}}$ PicoGreen ${ }^{\circledR}$ dsDNA 
Reagents and Kits, 2005). This method quantifies all types of DNA but it does not distinguish between human and non-human DNA.

Promega's AluQuant ${ }^{\mathrm{TM}}$ Human DNA Quantification System quantifies only human DNA and could be used for forensic samples. This method uses a human specific probe that binds to repeating sequences that can be detected without amplification. The binding of the probe initiates a series of enzymatic reactions. This leads to the production of ATP that is then used by luciferase to produce a luminescent signal which is proportional to the concentration of human DNA. The range of detection is between 0.150ng of human DNA. Quantification of DNA from bacteria or fungi that typically contaminates forensic samples was found to be insignificant (Mandrekar et. al., 2001).

Many forensic laboratories previously used slot blot quantification to quantify human DNA. DNA is captured on a nylon membrane and a human specific probe is added to the membrane followed by several washes. Chemiluminescense or colorimetric signals are used for detection and are compared to a set of standards. This method detects both single stranded and double stranded DNA and can detect as little as 10-20pg of DNA (Butler, 2005).

A relatively new technology involves the use of real time polymerase chain reaction (PCR) to quantify DNA. Quantitative real time PCR uses amplification of target DNA coupled with a fluorometer to measure the change in signal during every cycle. The fluorescence at each cycle is proportional to the starting amount of DNA and can be quantified using a standard curve. It is best to determine quantification during the exponential part of amplification. A threshold value is determined and the cycle number when the amplification curve crosses the threshold is the crossing point $(\mathrm{Cp})$ and this is 
used to calculate the concentration. Melting curves are used to calculate the melting temperature of each amplicon to determine if there has been non-specific amplification. Melting temperatures of an amplicon depends on the size of the product and the GC content (Frackman et. al., 2005). Roche LightCycler $®$ kits with human short tandem repeat (STR) primers and Applied Biosystem's Quantifiler Human DNA Quantification kit can also be used to quantify human DNA. The Quantifiler has a detection range of $0.023 \mathrm{ng} / \mu 1$ to more than $50 \mathrm{ng} / \mu 1$.

\section{Short Tandem Repeats}

Short tandem repeats (STRs) are an important aspect of forensic DNA profiling. They are composed of short sequences of DNA that are repeated in tandem. Unlike minisatellites such as variable number of tandem repeats (VNTRs) which have repeating sequences of 9-80 base pairs (bp), STRs contain only a core sequence of 2-5 repeating bp. Forensic analyses typically use STRs with $4 \mathrm{bp}$ called tetranucleotides (Ruitberg $e t$. al., 2001). Short tandem repeats are normally repeated 5-30 times (Tamaki \& Jeffreys, 2005). The DNA loci used are polymorphic and the number of repeating units varies enough among people in the population to give this type of forensic analysis a great enough degree of discrimination (Butler et. al., 2001). This is especially true when more than one STR is used. PCR is used to amplify STRs using primers designed specifically for the STR of interest. PCR allows for the analysis to be much more sensitive, only requiring between $0.5 n g-1 \mathrm{ng}$ of DNA. The PCR reactions are multiplexed which allows for as many as 13 STRs to be analyzed at once (Chakraborty et. al., 1999). The products from the PCR reaction are separated by electrophoresis to separate the alleles by size

which are detected using fluorescent labelling. There are many commercial kits available 
that are optimized for co-amplification of STRs as well as the sex marker amelogenin (Butler, 2005). Short tandem repeats to be used for forensic applications must be highly variable in the population and in a multiplex reaction the different STRs must be distinguishable from one another (Schumm, 1996).

\section{Short Tandem Repeats used in this study}

DNA analysis was performed to determine if there was any PCR interference or degradation of DNA due to contamination of bacteria or due to the introduction of a filtration step. DNA from lysed bacteria may compete with human DNA to bind to the magnetic resin in the DNA IQ System. When the bacteria are lysed the nucleases may also have an effect on the human DNA and could degrade the DNA. Bacterial DNA could also interfere with the dyes in PCR amplification and give poor results. For a quick analysis of samples two STRs were chosen. STR D3S1358 is located on chromosome 3p and has a size range of 114-142bp. D18S51 is located on chromosome 18q21.3 and has a size range of 273-341bp using Applied Biosystem's AmpFISTR. The reason why these two STRs were chosen was due to their size range, STR D3 is very small and should be found intact in all samples, whereas STR D18 would be more easily degraded due to its large size and would provide a good indication of DNA degradation. Loci from degraded DNA show a loss in amplification starting at the largest STR and samples with less DNA degradation show a balance between loci (Withrow et. al., 2003). At first each STR was analyzed separately and later on the two STRs were analyzed in the same PCR reaction so that more samples could be processed. This was performed in order to ensure there was amplifiable DNA present so that the samples could be sent to the RCMP for a full DNA analysis. At the RCMP the amplification kit AmpFISTR was used and 9 STRs were 
analyzed along with amelogenin. The STRs include D3S1358 (114-142bp), vWA (157197bp), FGA (219-267bp), D8S1179 (128-168bp), D21S11 (189-143bp), D18S51 (273$341 \mathrm{bp})$, D5S818 (135-171bp), D13S317 (206-234bp) and D7S820 (258-294bp).

\section{Purpose}

The purpose of the project was to make modifications to a human DNA extraction protocol in order to render samples contaminated with risk group 3 bacteria safe for forensic analysis. The current DNA extraction protocol used for forensic samples does not inactivate bacterial spores and in some cases vegetative bacteria. The lysis step involves heating to $56^{\circ} \mathrm{C}$ overnight, which is not enough to kill spores; therefore a filtration step was introduced. A $0.2 \mu \mathrm{m}$ centrifugal filter can be used after the DNA extraction in order to retain any bacteria not previously lysed or rinsed away during the procedure. This final filtration step allows for the DNA sample to be free of any contaminating bacteria so that the DNA quantification and amplification could be carried out in a forensic laboratory without the need for a higher containment laboratory. It would be very costly to design a containment level 3 laboratory for forensic analysis and it would be very difficult to process a large number of samples while wearing the appropriate personal protective equipment. Therefore removing contaminating bacteria before forensic analysis would be ideal.

Filters were tested with RG1, RG2 and RG3 bacteria to ensure that the filters were effective in retaining bacteria. Modifications were made to the DNA extraction procedure with blood being the primary source of DNA. DNA was also extracted from gum, hair, cigarettes and trace epithelial cells from latex gloves contaminated with RG1 and RG2 bacteria. The filtration step was added after lysis at $56^{\circ} \mathrm{C}$ overnight. DNA from 
blood contaminated with RG3 bacteria was also extracted and the filtration step was incorporated after elution of DNA from resin. All samples were tested for bacterial growth after the extraction procedure for safety quality control.

Quantification of DNA was performed using a non-specific quantification method to detect all DNA present using Invitrogen's Quant-iT PicoGreen and a fluorometer. Two human specific methods were also used: Promega's AluQuant $\mathbb{B}$ Human DNA Quantitation System with a luminometer for detection and quantitative real time PCR with Roche's LightCycler ${ }^{\circledR}$ FastStart DNA MasterPlus SYBR Green I kit. Quantification of DNA was used to ensure that enough DNA was present and to determine the amount to be used for real time PCR. A quick analysis of the samples was performed using primers for STRs D18 and D3 and was amplified using Roche's SYBR Green kit. Samples were sent to the RCMP for quantification and DNA typing using Applied Biosystems Quantifiler ${ }^{\mathrm{TM}}$ Human DNA Quantification Kit and AmpFISTR $(\mathbb{B}$ Profiler Plus ${ }^{\circledR}$ PCR Amplification Kit.

The two main goals of this research were to ensure that after using the modified DNA extraction procedure the samples were safe for handling outside a high containment laboratory and that the integrity of the human DNA was not compromised. This research project was the result of a collaboration between the Public Health Agency of Canada (PHAC) and the Royal Canadian Mounted Police (RCMP).

\section{Hypothesis}

I hypothesize that the contaminating bacterial DNA will not have any effect on PCR analysis or DNA profiling. I also hypothesize that the $0.2 \mu \mathrm{m}$ filters will be effective 
in removing contaminating bacteria and that they will not have any effect on DNA integrity. 


\section{MATERIALS AND METHODS}

\section{Sources of Bacteria}

Over the course of the experiments work was done with risk group 1, risk group 2 and risk group 3 bacteria. The following bacteria were used: Bacillus subtilis (vegetative and spores), Pseudomonas aeruginosa, Staphylococcus aureus, Bacillus anthracis (spores), Yersinia pestis, and Francisella tularensis (see Table 1).

\section{Growth Conditions}

Vegetative Bacteria: Vegetative bacteria (S. aureus, $P$. aeruginosa and B. subtilis) were cultured either by adding a culture bead from cryostor microbiology culture preservation vials (Innovatek Medical Inc, Vancouver, BC) into tryptone soya broth (TSB, Oxoid, Nepean, ON) or by streaking a bead onto tryptic soy agar (TSA, Oxoid) and incubating overnight at $35^{\circ} \mathrm{C}$. For $Y$. pestis beads were either added to TSB or to sheep blood agar $\left(5 \%\right.$, Oxoid) and incubated at $35^{\circ} \mathrm{C}$ for $24-48 \mathrm{hrs}$. F. tularensis grew more favourably when plated on chocolate agar (Oxoid) and placed inside a plastic bag with $\mathrm{CO}_{2}$ gen compact (Oxoid) and incubated at $35^{\circ} \mathrm{C}$ for $48-72 \mathrm{hrs}$.

Spores: Spore suspensions were made by adding a culture bead into two $50 \mathrm{ml}$ flasks containing $1 / 10$ Columbia broth $(\mathrm{BD}$, Oakville, $\mathrm{ON})$ with $10 \mathrm{mM}$ manganese sulphate monohydrate $\left(\mathrm{MnSO}_{4} \cdot \mathrm{H}_{2} 0, \mathrm{EMD}\right)$. Flasks were incubated at $37^{\circ} \mathrm{C}$ on an Incubator/Shaker (New Brunswick, Edison, NJ) at 160rpm for 48-96hrs. The spore suspensions were centrifuged at $4150 \mathrm{xg}$ for $20 \mathrm{~min}$ at $4^{\circ} \mathrm{C}$ on the Sorvall Heraeus Centrifuge Multifuge 2S-R (Thermo Fisher Scientific, Nepean, ON). The two pellets were pooled together and washed with $40 \mathrm{ml}$ of sterile deionized ultra filtered (DIUF) water. Centrifugation was 
Table 1 - List of bacterial organisms used in research project

\begin{tabular}{|c|c|c|c|c|}
\hline Organism & $\begin{array}{c}\text { Strain } \\
\text { Number }\end{array}$ & $\begin{array}{c}\text { Risk } \\
\text { Group }\end{array}$ & Obtained from & Date \\
\hline $\begin{array}{c}\text { Bacillus } \\
\text { subtilis }\end{array}$ & $\begin{array}{c}\text { ATCC } \\
19659\end{array}$ & 1 & $\begin{array}{c}\text { Dr. Sayed Sattar } \\
\text { University of } \\
\text { Ottawa }\end{array}$ & $2004-01-12$ \\
\hline $\begin{array}{c}\text { Staphylococcus } \\
\text { aureus }\end{array}$ & $\begin{array}{c}\text { ATCC } \\
6538\end{array}$ & 2 & $\begin{array}{c}\text { Dr. Sayed Sattar } \\
\text { U of O }\end{array}$ & $2004-01-12$ \\
\hline $\begin{array}{c}\text { Pseudomonas } \\
\text { aeruginosa }\end{array}$ & $\begin{array}{c}\text { ATCC } \\
15442\end{array}$ & 2 & $\begin{array}{c}\text { Dr. Sayed Sattar } \\
\text { U of O }\end{array}$ & $2004-01-12$ \\
\hline $\begin{array}{c}\text { Bacillus } \\
\text { anthracis } \\
\text { Sterne strain } \\
\text { (attenuated) }\end{array}$ & 2 & $\begin{array}{c}\text { Dr. Wayne Conlan } \\
\text { National Research } \\
\text { Council }\end{array}$ & $2004-06-22$ \\
\hline $\begin{array}{c}\text { Bacillus } \\
\text { anthracis }\end{array}$ & $\begin{array}{c}\text { NML } \\
03-0191\end{array}$ & 3 & $\begin{array}{c}\text { Kathy Bernard } \\
\text { National } \\
\text { Microbiology } \\
\text { Laboratory }\end{array}$ & $2005-05-05$ \\
\hline $\begin{array}{c}\text { Yersinia pestis } \\
\text { Francisella } \\
\text { tularensis }\end{array}$ & $\begin{array}{c}\text { NML } \\
03-0083\end{array}$ & 3 & $\begin{array}{c}\text { Kathy Bernard } \\
\text { NML }\end{array}$ & $2005-05-05$ \\
\hline
\end{tabular}


repeated at $4150 \mathrm{~g}$ for $20 \mathrm{~min}$ at $4^{\circ} \mathrm{C}$ and the pellet was resuspended in $5 \mathrm{ml}$ of sterile DIUF water and stored at $4^{\circ} \mathrm{C}$.

Enumeration: Bacterial suspensions were serially diluted and the $10^{-6}, 10^{-7}$ and $10^{-8}$ dilutions $(100 \mu \mathrm{l})$ were plated onto appropriate medium and grown overnight at $35^{\circ} \mathrm{C}$ in an incubator. For spore suspensions, $200 \mu \mathrm{l}$ of the spore suspension was heat inactivated (HI) at $80^{\circ} \mathrm{C}$ for $10 \mathrm{~min}$ in a water bath (Fisher Scientific Water Bath Isotemp 202). The sample was serial diluted and again the $10^{-6}, 10^{-7}$ and $10^{-8}$ dilutions $(100 \mu l)$ were plated onto TSA and grown overnight at $35^{\circ} \mathrm{C}$. Colonies were counted and the sample that was heat inactivated represented the number of spores whereas the sample that was not heat inactivated is the total number of vegetative bacteria plus spores.

\section{Containment Level 3 (CL3) Personal Protective Equipment (PPE)}

In order to work in a containment level 3 laboratory certain articles of clothing and PPE must be worn for safety. Scrubs were worn with Tyvek ${ }^{\circledR}$ coveralls overtop and a hood with a powered air purifying respirator (PAPR) in order to protect against aerosols. Boot covers and 2 pairs of long cuffed gloves were worn and a third pair of gloves was worn while working in the biological safety cabinet (BSC). All clothing and disposable PPE were removed in the dirty change room and were autoclaved prior to removal from the CL3 lab. A shower was taken every time before exiting the lab. The amount of time and effort it takes to don and doff clothing and PPE for CL3 and the strict precautions that are taken while working in containment CL3 make it more desirable to render the samples safe enough for analysis outside of a CL3 laboratory. 


\section{Quality Control of $0.2 \mu \mathrm{m}$ filters}

The Ultrafree $®-M C$ centrifugal filter unit is a microporous filter unit with a $0.2 \mu \mathrm{m}$ low binding Durapore ${ }^{\circledR}$ Polyvinylidene Chloride (PVDC) membrane. The filters have a maximum spin G-force of $12,000 \mathrm{xg}$ and can be spun for 1-4min. The filter cup can hold up to $500 \mu 1$ and has a hold up volume of $5 \mu 1$.

CL2: Filters (Millipore Ultrafree ${ }^{\circledR}-M C$ Centrifugal Filter Unit $-0.22 \mu \mathrm{m}$, sterile, from Fisher Scientific) were tested by adding $250 \mu \mathrm{l}$ of bacterial suspension to filter, centrifuging at $9,300 \mathrm{xg}$ for $1.5 \mathrm{~min}$, rinsing with $150 \mu \mathrm{l}$ of suspension and centrifuging again at $9,300 \mathrm{xg}$ for $1.5 \mathrm{~min}$. The filtrate was then plated onto 3 TSA plates and incubated for 7 days. Growth was checked the following day and after 7 days. If growth was present a gram stain was performed to determine if it could be the organism used or just

environmental contamination. Bacteria were also identified using Biolog Microlog ${ }^{\mathrm{TM}}$ System (Biolog; Hayward, CA).

CL3: Filters were tested in CL3 laboratory by adding $100 \mu$ of bacterial suspension to the filter and centrifuging at $10,000 \times \mathrm{xg}$ for $2 \mathrm{~min}$. The caps of the tubes were cut off and the filter baskets were removed. The filtrate was then plated onto media and left in the incubator for 2 weeks. The integrity of the filter baskets post-centrifugation was inspected visually. As a control, $100 \mu$ l of phosphate buffered saline (PBS) was added to the top of one of the filters (for all 3 organisms). The solution was pipetted up and down and plated onto media. This was to verify that the organism will grow and to ensure that organism was actually added to the filters. Growth was checked the following day, after one week and after two weeks. 


\section{Biolog Bacterial Identification:}

Bacteria were identified using the Biolog Microlog ${ }^{\mathrm{TM}}$ System according to the manufacture's protocol. Microlog uses a 96 microtitre plate containing 95 different carbon sources which are used by the microorganisms. When a carbon source is used the wells change color resulting in a unique pattern that identifies the bacteria.

\section{DNA Extraction}

\section{Sample types:}

Blood: Blood was taken using a $21 \mathrm{G}^{3} 3 / 4 \mathrm{BD}$ vacutainer needle and a BD vacutainer tube (with $\mathrm{K}_{2} \mathrm{EDTA}$ ). Blood was donated from male and female volunteers and the same subjects were used throughout the study. Tubes of blood were stored in the fridge at $4^{\circ} \mathrm{C}$ and used for a maximum of 1 week.

Blood spotted on paper: Whatman 3 cellulose filter disks were cut out using a hole punch, placed onto a glass Petri dish and autoclaved on dry cycle for $20 \mathrm{~min} .1 \mu \mathrm{l}$ of blood (whole blood, in $\mathrm{K}_{2}$ EDTA) was mixed with either $9 \mu$ of bacteria or saline. The mixture was pipetted onto a disk and allowed to dry for 1 hour. Afterwards the disks were placed in $250 \mu \mathrm{l}$ of lysis buffer and DNA was extracted as described below.

For the following samples $100 \mu 1$ of bacterial suspension or $100 \mu$ l of $10 \mathrm{X}$ bacterial suspension (10X bacterial suspension centrifuged bacteria 2,500xg for $20 \mathrm{~min}$, resuspended in $1 \mathrm{ml}$ of sterile saline) was added to the human sample types. For human only samples, saline was added instead of bacteria. For bacteria only samples, bacteria were added along with sample substrates where appropriate (gum, cigarettes, swab without human epithelial and buccal cells). Sample tubes contained stain extraction buffer $(230 \mu \mathrm{l}$ SEB $+20 \mu 1$ Proteinase K). 
Blood added directly in tube (later switched to this method): $1 \mu$ l of blood was mixed with $100 \mu \mathrm{l}$ of bacteria (different concentrations) or saline. The mixture was added directly to a tube.

Hair: Hair was plucked from the head using tweezers and placed in a sterile bag. The end of the hair with the root was cut to approx $6 \mathrm{~mm}$.

Gum: The type of gum that was used was Trident spearmint sugar free gum. It was chewed for $15 \mathrm{~min}$ then placed in a sterile Petri dish. Gum was cut into 9 pieces using sterile scalpel and forceps. Each piece was placed into a separate tube. A piece of gum that had not been chewed was cut up into 9 pieces and used for bacteria only samples. The gum was centrifuged in the $0.2 \mu \mathrm{m}$ filter along with the liquid.

Cigarette: Cigarettes used were Players Light cigarette tubes, king size, (John Player \& Sons, Montréal, QC). Operators placed the cigarettes in the mouth and pretended to smoke cigarettes (filter and tube, with no tobacco). Approximately 10 puffs were taken from the cigarette. Only the paper around the filter was used; the filter and inside paper lining were removed from the outer paper. Only half of the paper was used per sample; it was cut in 4 pieces placed in a tube. The paper was centrifuged in the $0.2 \mu \mathrm{m}$ filter along with liquid, sometimes liquid remained because the paper was clogging the filter. Styrofoam Cups: Clean Styrofoam coffee cups were applied to the lips of human subjects imitating a sipping action 10 times. The coffee cups were then swabbed with pre-moistened Dacron swabs. The swabs were cut and placed in microfuge tubes. Pencil: A new mechanical pencil was handled for $10 \mathrm{~min}$ and then the entire pencil was swabbed with a moistened Dacron swab. 
Buccal Swab: Buccal cells were collected by swabbing the inside cheek with a swab. All samples were placed in $250 \mu \mathrm{l}$ of SEB and incubated overnight at $56^{\circ} \mathrm{C}$.

Latex gloves: The types of gloves that were used were Kimberly Clark Safeskin health touch, powder-free latex exam gloves with vitamin $\mathrm{E}$ and emollients, small and large. Gloves were worn for $10 \mathrm{~min}$ while working in the office and the lab. The inside of the glove was swabbed using a cotton tip swab moistened with sterile water. Every finger and top part of the palm was swabbed. The swab was cut to appropriate size and placed in a tube. The samples were centrifuged with the cotton swab in the $0.2 \mu \mathrm{m}$ filter.

DNA Extraction for CL2: DNA was extracted using Promega's DNA IQ ${ }^{\mathrm{TM}}$ system. The protocol followed was Promega technical bulletin no. 296 that was modified by the RCMP. A few changes were made to the RCMP's protocol in order to render the samples safe for analysis. A volume of $230 \mu \mathrm{l}$ of stain extraction buffer $(100 \mathrm{mM} \mathrm{NaCl}, 10 \mathrm{mM}$ Tris $\mathrm{HCl}, \mathrm{pH} 8.0,10 \mathrm{mM}$ EDTA $0.5 \%$ sarkosyl and $40 \mathrm{mM}$ DTT) and $20 \mu \mathrm{l}$ of Proteinase K (Promega; Madison, WI, final $1.5 \mathrm{mg} / \mathrm{ml}$ ) was added to each sample tube. Samples were mixed and it was ensured that the sample material was completely immersed in solution. Tubes were incubated at $56^{\circ} \mathrm{C}$ overnight $(18 \mathrm{hrs})$ in a water bath.

The tubes were then centrifuged at high speed for 30s. The sample was then transferred to a $0.2 \mu \mathrm{m}$ filter tube (Millipore Ultrafree $(\mathrm{B}-\mathrm{MC}$ Centrifugal Filter Unit, Carrigtwohill, Co. Cork, Ireland) and centrifuged at 10,000xg for $2 \mathrm{~min}$. A volume of $150 \mu \mathrm{l}$ of lysis buffer (Promega, no DTT) was added to the filter and spun again at $10,000 \mathrm{xg}$ for $2 \mathrm{~min}$. The lids of the tubes were cut off and the filters were removed. The sample was then transferred to a new microcentrifuge tube. A volume of $350 \mu$ l of lysis buffer (Promega, no DTT) was added to the tubes followed by $12 \mu \mathrm{l}$ of resin (resin was 
vortexed for 10 s before adding). Samples were vortexed and left for $5 \mathrm{~min}$ with periodic vortexing during the $5 \mathrm{~min}$ to ensure good bead/DNA contact.

The samples were placed on the magnetic stand and the solution was discarded. A volume of $200 \mu 1$ of lysis buffer (Promega, no DTT) was added to the sample, vortexed for $5 \mathrm{~s}$ and centrifuged at high speed for $30 \mathrm{~s}$. The sample was vortexed, placed on magnetic stand and the solution was removed. A volume of $200 \mu$ l of wash buffer was added to the sample, was vortexed, placed back on the stand and the solution was removed. This was repeated once. Sample was left to air dry for $5 \mathrm{~min}$ (It was never left for more than 20min since DNA would become irreversibly bound to the resin at this point). Elution buffer (Promega, 50 $\mu \mathrm{l}$ ) was added, vortexed and placed in a water bath to incubate at $65^{\circ} \mathrm{C}$ for $8 \mathrm{~min}$. Samples were placed back on magnetic stand and the DNA was placed in clean $2 \mathrm{ml}$ tube and stored at $-20^{\circ} \mathrm{C}$. Ten percent of the DNA $(5 \mu \mathrm{l})$ was taken and plated on the appropriate medium and incubated for 2 weeks at $35^{\circ} \mathrm{C}$. Final CL3 DNA extraction procedure (Figure 1): There were a few changes made to the CL2 DNA extraction procedure in order to ensure that the final product was safe enough to remove from the containment level 3 laboratory. The procedure is as follows:

A volume of $230 \mu \mathrm{l}$ of stain extraction buffer and $20 \mu \mathrm{l}$ of ProK (Promega, final $1.5 \mathrm{mg} / \mathrm{ml}$ ) was added to each sample tube. Tubes were incubated at $56^{\circ} \mathrm{C}$ overnight (18hrs) in a water bath.

The next day the tubes were pulse spun for $10 \mathrm{~s}$ and $500 \mu \mathrm{l}$ of lysis buffer (Promega, no DTT) was added along with $12 \mu 1$ of resin. Samples were vortexed and left for 5 min with periodic vortexing during the $5 \mathrm{~min}$ to ensure good bead/DNA contact. They were then placed on the magnetic stand and the solution was discarded. A volume 


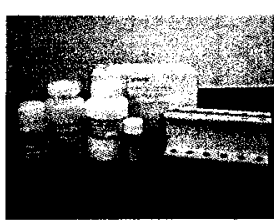

Lysis Step: Overnight lysis in a waterbath at $56^{\circ} \mathrm{C}$ to release DNA from cells

Binding step: DNA binds to magnetic resin $5 \mathrm{~min}$

Washing step: Wash with lysis buffer $\times 1$, wash buffer $x 2$

Elution Step: Elute from resin, place in water bath at $65^{\circ} \mathrm{C}$ for $8 \mathrm{~min}$

Filtration Step: Filter DNA extraction through 0.2um Millipore centrifugal filter, by centrifuging at $10,000 \times \mathrm{xg}$ for $2 \mathrm{~min}$

Safety Quality Control: Use half of DNA extraction to inoculate appropriate culture media and incubate for 2 weeks at $35^{\circ} \mathrm{C}$

Removal from level 3: Once samples are determined to be negative for bacterial growth, remove samples from level 3 laboratory by bleaching outside of samples

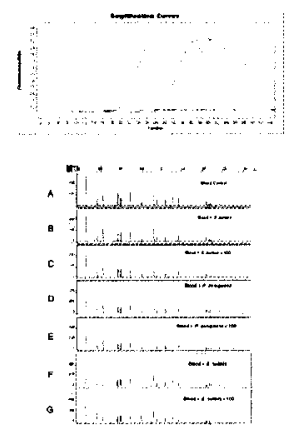

DNA Quality Control: Use LightCycler real time PCR with primers for short tandem repeats to ensure human DNA is present

Send Samples for Testing: Send samples to RCMP for DNA Profiling

Figure 1 - Flow Chart: DNA extraction and analysis of human samples potentially contaminated with risk group 3 bacteria 
of $200 \mu 1$ of lysis buffer (Promega, no DTT) was added to the sample, vortexed for $5 \mathrm{~s}$ and centrifuged at high speed for $30 \mathrm{~s}$. The sample was vortexed again, placed on magnetic stand and the solution was removed. A volume of $200 \mu$ l of wash buffer was added to the sample, was vortexed, placed back on the stand and the solution was removed. This was repeated once. Sample was left to air dry for $5 \mathrm{~min}$ and then elution buffer (Promega, $105 \mu 1)$ was added, the sample was vortexed and placed in a water bath to incubate at $65^{\circ} \mathrm{C}$ for $8 \mathrm{~min}$. Samples were placed back on magnetic stand and DNA was placed in a sterile $0.2 \mu \mathrm{m}$ filter tube and centrifuged at $10,000 \mathrm{xg}$ for $2 \mathrm{~min}$. Half (approx $50 \mu \mathrm{l}$ ) of the DNA extraction was then placed in a sterile $2 \mathrm{ml}$ tube and stored at $-20^{\circ} \mathrm{C}$. The other half of the DNA extraction $(50 \mu \mathrm{l})$ was taken and cultured on appropriate medium and incubated at $35^{\circ} \mathrm{C}$. Cultures were observed for growth for 14 days.

Removing DNA extractions from CL3 : Samples negative for growth were wrapped in paper towel and placed in an evidence bag and soaked with 1:5 solution of bleach. The bag was sealed and the outside was rinsed with bleach and placed in a TC-125-1 A container (Saf-T-Pak Inc, Edmonton, AB). The inside and outside of the 1A container were rinsed with bleach prior to adding the bag. Before leaving the lab the outside of the $1 \mathrm{~A}$ container was rinsed again with bleach. Samples were stored in the $-20^{\circ} \mathrm{C}$ freezer in the CL2 laboratory until needed. To remove the samples from the container the evidence bag was rinsed again with bleach and the samples inside were rinsed with bleach and water. All work was done inside a biological safety cabinet. 


\section{Total DNA Quantification}

PicoGreen: Total DNA was quantified using PicoGreen ${ }^{\circledR}$ dsDNA Quantitation Kit (Molecular Probes: Eugene, OR) according to the manufacturer's protocol. A standard curve was made using Lambda DNA that was supplied in the kit. Reaction volumes were $20 \mu \mathrm{l}(15 \mu \mathrm{l}$ PicoGreen $+5 \mu \mathrm{l}$ DNA $)$ and were placed in capillary tubes and centrifuged at 1,000rpm for 10s. Samples were read on the LightCycler (Roche: Laval, QC) using real time fluorescence.

\section{Human DNA Quantification}

AluQuant: Total human DNA was quantified using AluQuant $®$ Human DNA Quantitation System (Promega: Madison, WI) according to the manufacturers protocol (technical bulletin no. 291). Reactions were read using Turner Biosystems 20/20n Luminometer (Sunnyvale, CA).

qPCR: A second method of quantifying DNA was used and was found to be more successful. The LightCycler FastStart DNA MasterPlus SYBR Green I Kit was used on the LightCycler (Roche) according to manufacturer's protocol. For PCR reactions with one primer the samples contained $9 \mu 1$ water (PCR grade), $2 \mu 1$ primer (10x conc.), $4 \mu 1$ master mix (5x conc.) and $5 \mu$ l of DNA. For PCR reactions with two primers the samples contained $7 \mu \mathrm{l}$ water (PCR grade), $4 \mu \mathrm{l}$ primer (10x conc.), $4 \mu \mathrm{l}$ master mix (5x conc.) and $5 \mu 1$ of DNA. A standard curve was generated using human genomic DNA standard from the Promega AluQuant kit. The primer sequences for human short tandem repeats (STR) D18S51 and D3S1358 were found on a STR database (www.cstl.nist.gov/biotech/strbase) (D18: Urquhart et. al., 1995; Barber \& Parkin, 1996, D3: Li et. al., 1993; Perez-Lezaun 
Table 2 - Short tandem repeat D18 and D3 primer information

\begin{tabular}{|l|l|l|l|l|}
\hline Name & Gene & Sequence & $\begin{array}{l}\text { Melting } \\
\text { Point }\end{array}$ & $\begin{array}{l}\text { Product } \\
\text { Length }\end{array}$ \\
\hline D3F & $\begin{array}{l}\text { STR D3S1358 } \\
\text { (AGAT strand) }\end{array}$ & $5^{\prime}$-ACTGCAGTCCAATCTGGGT-3' & $58^{\circ} \mathrm{C}$ & $99-147 \mathrm{bp}$ \\
\hline D3R & $\begin{array}{l}\text { STR D3S1358 } \\
\text { (TCTA strand) }\end{array}$ & $5^{\prime}$-ATGAAATCAACAGAGGCTTG-3 & $55^{\circ} \mathrm{C}$ & $99-147 \mathrm{bp}$ \\
\hline D18F & $\begin{array}{l}\text { D18S51 } \\
\text { (AGAA strand) }\end{array}$ & $5^{\prime}$-CAAACCCGACTACCAGCAAC-3' & $61^{\circ} \mathrm{C}$ & $262-342 \mathrm{bp}$ \\
\hline D18R & $\begin{array}{l}\text { D18S51 } \\
\text { (AGAA strand) }\end{array}$ & $5^{\prime}$-GAGCCATGTTCATGCCACTG-3' & $63^{\circ} \mathrm{C}$ & $262-342 \mathrm{bp}$ \\
\hline
\end{tabular}


et. al., 1997). Primers were custom made from Invitrogen (Burlingon, ON) and were of desalt purity, $1 \mathrm{U}$ scale of synthesis. PCR conditions are listed in Table 3

\section{Gel Electrophoresis}

Gels were made with $2 \%$ agarose in either $1 \mathrm{X}$ Tris-Acetate-ethylenediamine tetra acetic acid (TAE) or $1 \mathrm{X}$ Tris-Borate-EDTA (TBE), with a total volume of $30 \mathrm{ml}$. Samples were diluted in Promega 6x blue/orange loading dye using $5 \mu 1$ of sample with $2 \mu \mathrm{l}$ of dye. The DNA ladder was a $100 \mathrm{bp}$ bench top ladder by Promega. The gel was run at $70 \mathrm{~V}$ for 75min using either $1 \mathrm{X}$ TAE or $1 \mathrm{X}$ TBE as a running buffer. The gels were stained in SYBR safe gel stain (Molecular Probes: Eugene, OR) for 30min and then photographed using Biorad ChemiDoc XRS (Bio-Rad Laboratories Ltd: Mississauga, ON).

\section{DNA Typing}

DNA samples were quantified and analyzed by James Elliott at the RCMP in Ottawa, Canada, following RCMP Operational Biology Guidelines. Samples were processed by hand rather then automated in a 96 well plate due to small number of samples. $2.5 \mu 1$ of sample was used to quantify DNA using Quantifiler ${ }^{\mathrm{TM}}$ Human DNA Quantification Kit in the ABI Prism ${ }^{\circledR} 7000$ Sequence Detection System and K562 DNA was used as a human DNA standard (Promega, $623 \mu \mathrm{g} / \mathrm{mL}$, total $30 \mu \mathrm{g}$ ). Samples (0.51ng of DNA) were amplified using the AmpFISTR $®$ Profiler Plus ${ }^{\circledR}$ PCR Amplification Kit (Applied Biosystems; Foster City, CA) in the PTC-200 DNA Engine Thermal cycler (MJ Research; Waltham, MA). The amplicons were run on the ABI Prism® 3100 Genetic Analyzer (Applied Biosystems). DNA that did not give a readable profile was

cleaned up and concentrated using Montage ${ }^{\mathrm{TM}}$ PCR Centrifugal Filter Devices (Millipore Corp.; Bedford, MA). 
Table 3 - Experimental protocol for real time PCR using Roche LightCycler FastStart MasterPlus SYBR Green I kit on the LightCycler

Program : Preincubation Type: None

\begin{tabular}{|l|l|l|l|l|}
\hline Number & $\begin{array}{c}\text { Temperature } \\
\left({ }^{\circ} \mathrm{C}\right)\end{array}$ & $\begin{array}{c}\text { Hold Time } \\
(\mathbf{s e c})\end{array}$ & Slope $\left({ }^{\circ} \mathrm{C} / \mathrm{sec}\right)$ & $\begin{array}{c}\text { Acquisition } \\
\text { Mode }\end{array}$ \\
\hline 1 & 95 & 600 & 20 & None \\
\hline
\end{tabular}

Program: PCR amplification Type: Quantification Cycle \# : 35-45

\begin{tabular}{|l|l|l|l|l|}
\hline Number & $\begin{array}{c}\text { Temperature } \\
\left({ }^{\circ} \mathbf{C}\right)\end{array}$ & \multicolumn{1}{|c|}{$\begin{array}{c}\text { Hold Time } \\
(\mathbf{s e c})\end{array}$} & Slope $\left({ }^{\circ} \mathbf{C} / \mathbf{s e c}\right)$ & \multicolumn{1}{|c|}{$\begin{array}{c}\text { Acquisition } \\
\text { Mode }\end{array}$} \\
\hline 1 & 95 & 10 & 20 & None \\
\hline 2 & 55 & 10 & 20 & None \\
\hline 3 & 72 & 10 & 20 & Single \\
\hline
\end{tabular}

Program: melting curve Type: melting curve

Cycle \# : 1

\begin{tabular}{|l|l|l|l|l|}
\hline Number & $\begin{array}{c}\text { Temperature } \\
\left({ }^{\circ} \mathbf{C}\right)\end{array}$ & \multicolumn{1}{|c|}{$\begin{array}{c}\text { Hold Time } \\
(\mathbf{s e c})\end{array}$} & Slope $\left({ }^{\circ} \mathbf{C} / \mathbf{s e c}\right)$ & \multicolumn{1}{|c|}{$\begin{array}{c}\text { Acquisition } \\
\text { Mode }\end{array}$} \\
\hline 1 & 95 & 0 & 20 & None \\
\hline 2 & 56 & 15 & 20 & None \\
\hline 3 & 95 & 0 & 0.1 & Continuous \\
\hline
\end{tabular}

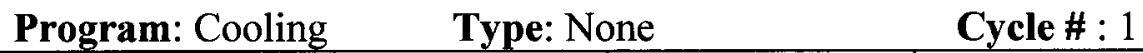

\begin{tabular}{|l|l|l|l|l|}
\hline Number & $\begin{array}{c}\text { Temperature } \\
\left({ }^{\circ} \mathrm{C}\right)\end{array}$ & $\begin{array}{c}\text { Hold Time } \\
(\mathbf{s e c})\end{array}$ & Slope $\left({ }^{\circ} \mathrm{C} / \mathrm{sec}\right)$ & $\begin{array}{c}\text { Acquisition } \\
\text { Mode }\end{array}$ \\
\hline 1 & 40 & 30 & 20 & None \\
\hline
\end{tabular}




\section{Biothreat Screening Kit}

DNA samples from CL3 were tested using RAPID testing - biothreat screening kit (Biochem, Idaho Technology, Salt Lake City, Utah) to verify that bacterial DNA can still be detected following a human DNA extraction protocol and a filtration step. Samples were run according to the manufacturer's protocol and were tested on Roche's LightCycler rather then the RAPID system. For the unknown DNA samples, $30 \mu 1$ of sterile water was added to the tubes and then pipetted into two separate capillaries. DNA $(5 \mu l)$ was then added to each capillary. 


\section{RESULTS:}

\section{Testing of Millipore $0.2 \mu \mathrm{m}$ filter: Effect of temperature and filter vs. spin basket}

Previous experiments (data not shown) demonstrated that the use of temperature $\left(95^{\circ} \mathrm{C}\right)$ and lysis buffer during DNA extraction could not guarantee complete inactivation of contaminating vegetative and spore forming bacteria. Therefore, it was decided that a centrifugation step with a $0.2 \mu \mathrm{m}$ filter would be incorporated into the protocol to physically remove any bacteria surviving the lysis step. Physically removing the bacteria from the sample should enable its analysis under less stringent biocontainment. In order to evaluate the efficiency of the $0.2 \mu \mathrm{m}$ filters on the retention of bacteria, the DNA IQ kit was used to lyse human blood cells with the addition of the filtration step after lysis for $30 \mathrm{~min}$ at $56^{\circ} \mathrm{C}$ or $95^{\circ} \mathrm{C}$. B. subtilis spores were used to demonstrate the effect of heat and filtration on spore forming bacteria and $S$. aureus was used to demonstrate the effect on vegetative, non-spore forming bacteria.

Filters vs. spin basket (Figure 2): The results indicated that the filters were capable of retaining the bacterial spores. No viable organism was found when lysis was conducted at either $56^{\circ} \mathrm{C}$ or $95^{\circ} \mathrm{C}$ when $0.2 \mu \mathrm{m}$ filters were used.

$5^{\circ} \mathrm{C}$ vs. $9^{\circ} \mathrm{C}$ (Figure 2): The results indicated that higher temperatures have a greater impact on the viability of the bacterial spores. At $56^{\circ} \mathrm{C}$, tests using a spin basket, resulted in colonies that were too numerous to count (estimate of $>10^{3} \mathrm{CFU} / \mathrm{ml}$ ) but at $95^{\circ} \mathrm{C}$ the bacteria were killed in almost all tests (39 out of 40 tests had no bacteria, one test had 79 colonies). 
Vegetative bacteria (Figure 2): The same experiments were carried out with $S$. aureus, which is a vegetative bacterium that does not form an endospore. The results indicated that there was no survival of $S$. aureus when either the $0.2 \mu \mathrm{m}$ filter or spin basket was used. There was also no survival of $S$. aureus at both $56^{\circ} \mathrm{C}$ and $95^{\circ} \mathrm{C}$. This indicates that the vegetative organism were either being killed by the $56^{\circ} \mathrm{C}$ heat or the lysis buffer or their combination.

\section{Quality Assurance of $0.2 \mu \mathrm{m}$ filters with Risk Group 1 and 2 bacteria}

To further demonstrate the ability of the filters, 20 samples for $P$. aeruginosa, 20 samples for B. subtilis and 35 samples for $S$. aureus were tested. Testing was performed on 4 separate days with 2 different filter lots. 74 out of 75 filtrate samples had no growth after 1 week (Figure 3). One sample was too numerous to count for B. subtilis. This could have been due to contamination from the lab or breakage of filter.

Filters performed as expected; there was no recovery of organism after the filtration step. The rinse step plus extra centrifugation did not affect the ability of the filter to filter out bacteria. The filter appeared to be intact after every centrifugation step. The reduced speed and amount of time $(9,300 \mathrm{xg}, 1.5 \mathrm{~min})$ will be used in further experiments so that the maximum speed and time is never exceeded.

Note: One lot of filters was found to be defective. There was growth from 9 out of 20 samples (data not shown). The filters appeared to be torn or disintegrated after centrifugation. Water was added to the filters and the water leaked through the filter even before centrifuging. Therefore for quality control, the integrity of each lot of filters 


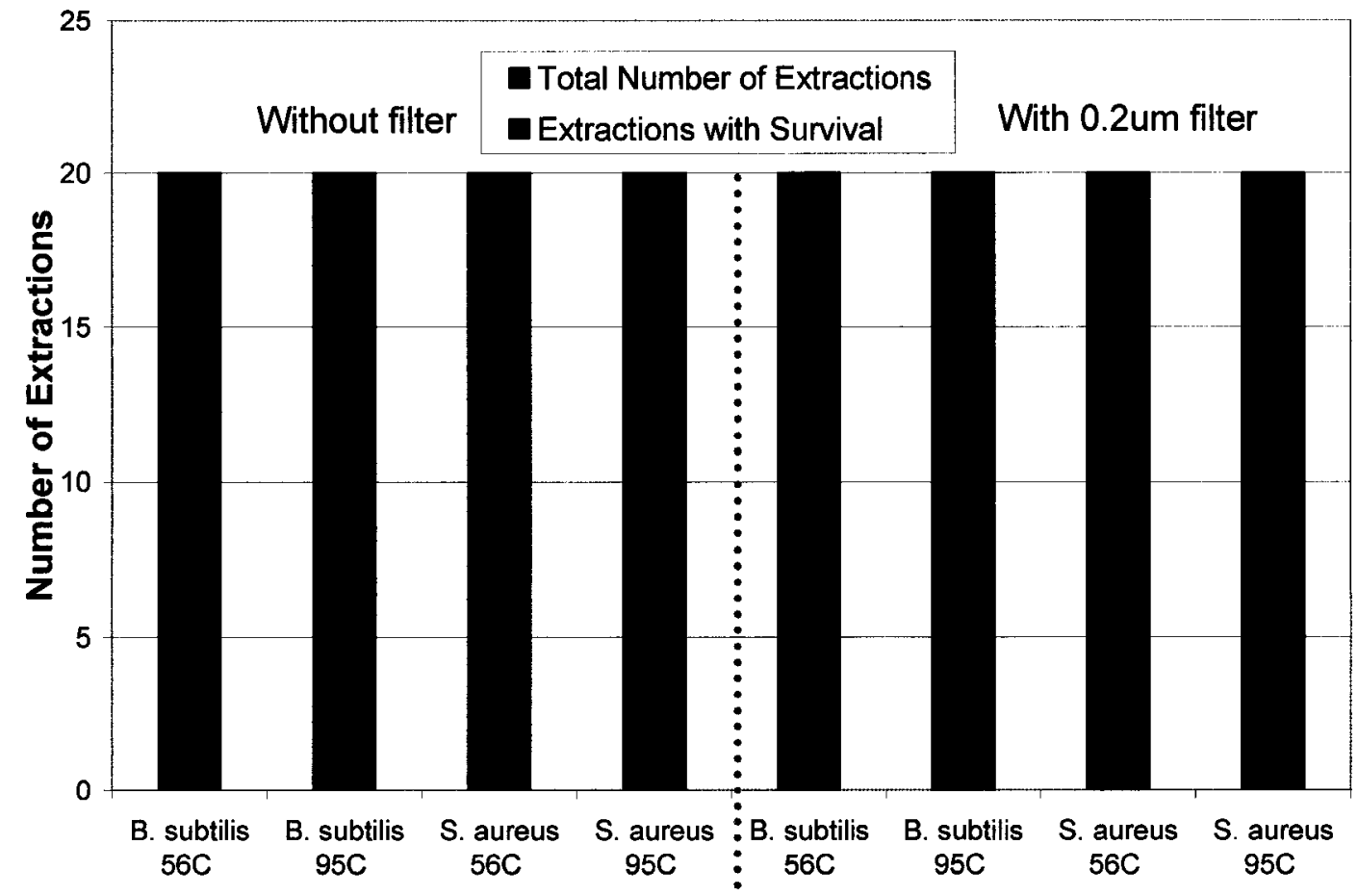

Figure 2 - Testing of Millipore $0.2 \mu \mathrm{m}$ Ultrafree ${ }^{\circledR}-\mathrm{MC}$ centrifugal filter with B. subtilis spores and $S$. aureus vegetative bacteria. Samples were lysed at either $56^{\circ} \mathrm{C}$ or $95^{\circ} \mathrm{C}$ in lysis buffer and centrifuged with either a $0.2 \mu \mathrm{m}$ filter or a spin basket. Samples were plated on TSA and incubated overnight at $35^{\circ} \mathrm{C}$. 


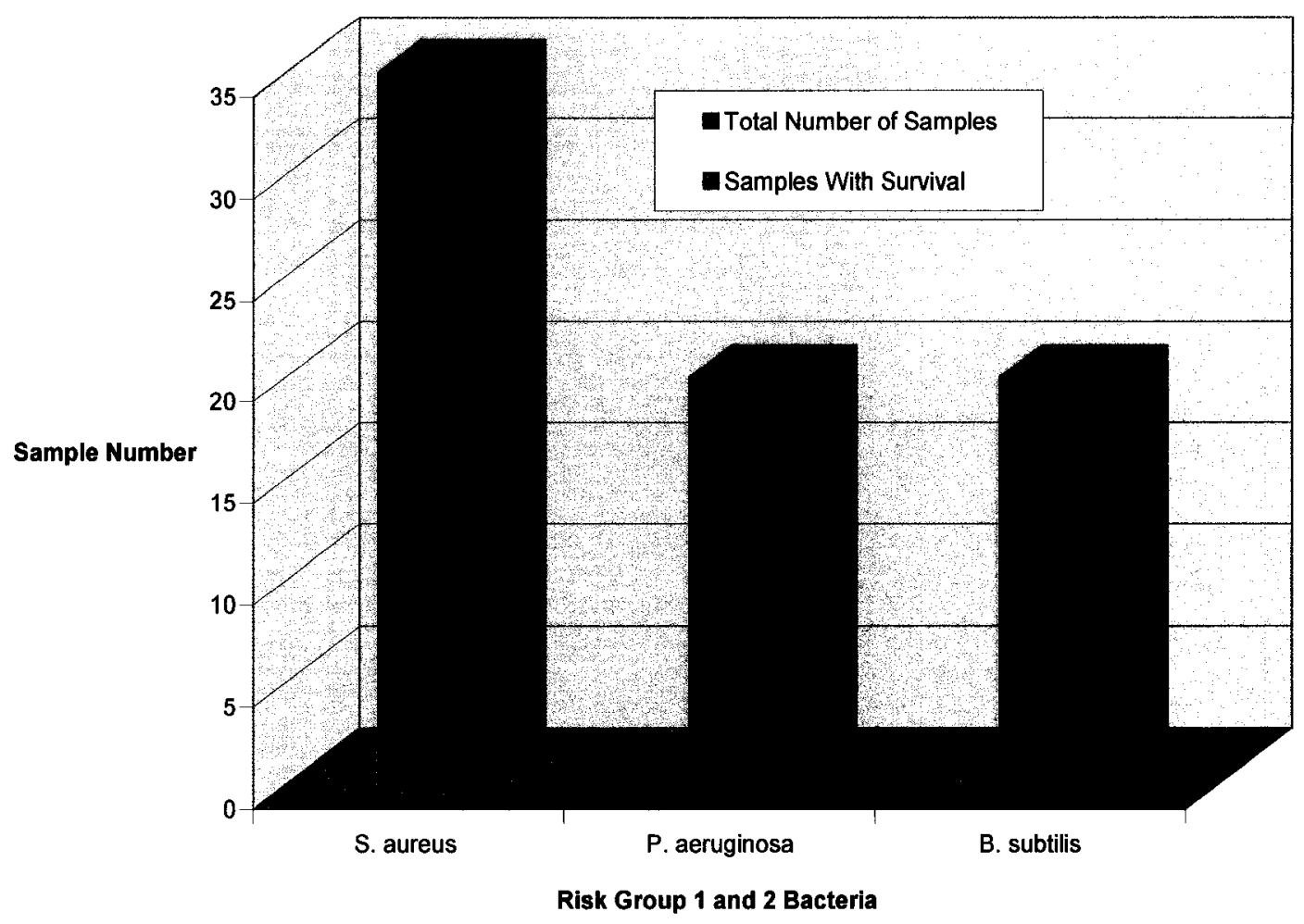

Survival of Risk Group 1 and 2 bacteria after centrifugation with a 0.2 um filter

Figure 3 - Testing of Millipore $0.2 \mu \mathrm{m}$ Ultrafree ${ }^{\circledR}-\mathrm{MC}$ centrifugal filter with risk group 1 and 2 bacteria. $S$. aureus, $P$. aeruginosa and $B$. subtilis vegetative bacteria were centrifuged with a $0.2 \mu \mathrm{m}$ filter in order to determine if the filter would effectively retain the bacteria. The filtrate was plated on TSA and incubated at $35^{\circ} \mathrm{C}$ for 1 week to check for growth. 
should be tested. DNA extractions should also be cultured every time to ensure no bacterial contamination is present.

\section{Quality Assurance of $0.2 \mu \mathrm{m}$ filters with Risk Group 2 and 3 bacteria}

Testing of the $0.2 \mu \mathrm{m}$ filters was redone on risk group 2 and 3 bacterial spores and vegetative bacteria. 100 filters were tested (20 B. anthracis Sterne strain spores, 40 B. anthracis spores, 20 Francisella tularensis and 20 Yersinia pestis). Samples were no longer rinsed in case the rinsing step and centrifuging the filter a second time was too much stress on the filter. The filtration step during the DNA extraction process was changed to after elution, therefore the sample volume was reduced to $100 \mu 1$ since that will be the volume after elution. Testing was performed on 3 separate days, with 2 different filter lots and 2 different operators. All filtrate samples were negative for growth after 14 days (Figure 4) and positive controls were positive. The filters were checked after centrifugation and all filters appeared to be intact.

\section{DNA Extraction from varying concentrations of blood contaminated with $S$. aureus}

The purpose of these experiments was to determine the limits of quantification and to determine the amount of blood to be used for future experiments.

DNA extraction using DNA IQ: Filter paper disks were inoculated with a fixed amount

of $S$. aureus $\left(\sim 1 \times 10^{5} \mathrm{cfu} / \mathrm{ml}\right)$ and varying amounts of anticoagulated $\left(\mathrm{K}_{3}\right.$ EDTA $)$ human blood. The disks were immediately placed in an eppendorf tube without drying. Lysis buffer was added and the samples were incubated at $56^{\circ} \mathrm{C}$ for 30 minutes. The contents of the tube were filtered by centrifugation using a $0.2 \mu \mathrm{m}$ filter. The remainder of the 


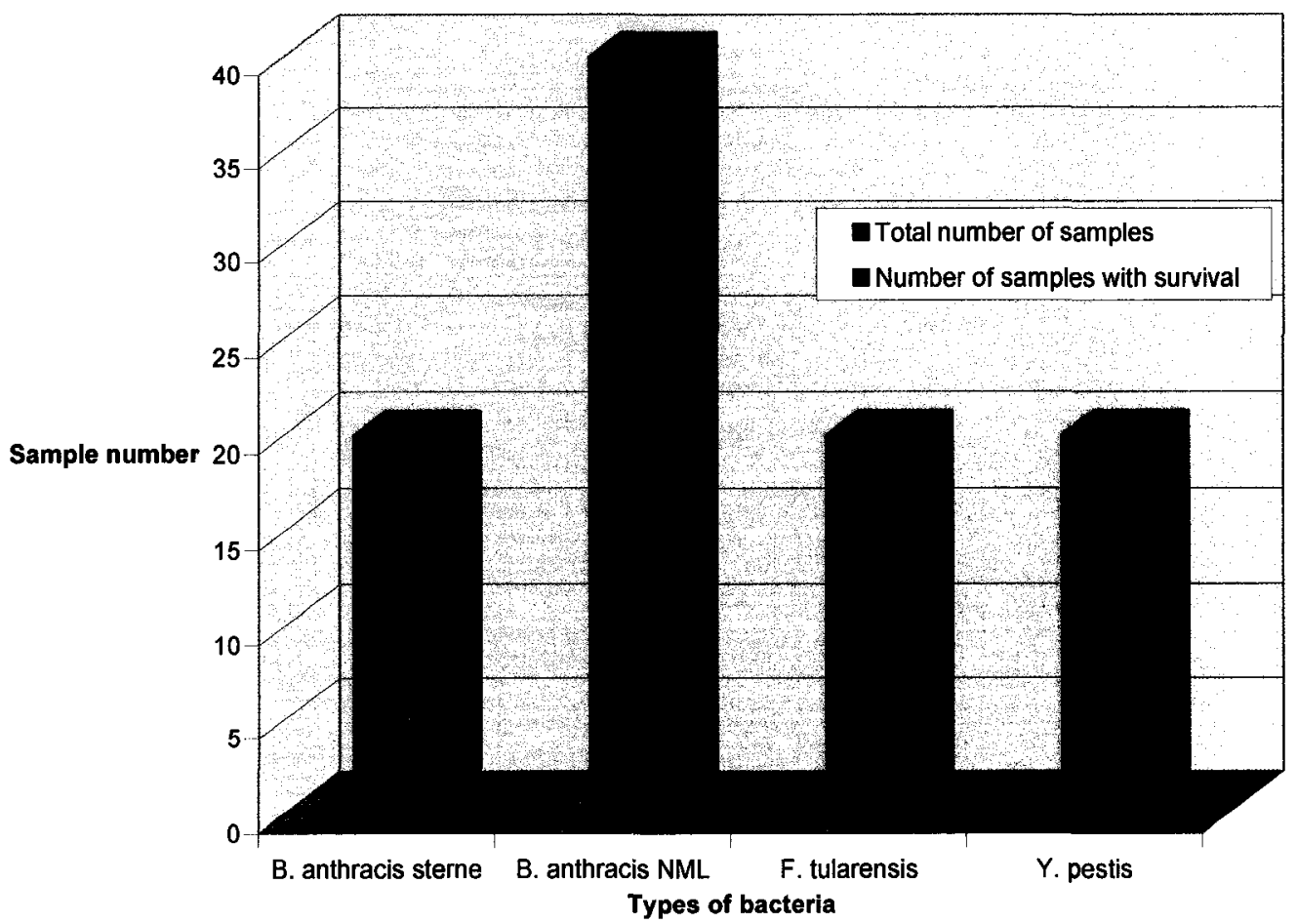

Survival of risk group 2 and risk group 3 bacteria after filtration with 0.2 um filter

Figure 4 - Testing of Millipore $0.2 \mu \mathrm{m}$ Ultrafree ${ }^{\circledR}-\mathrm{MC}$ centrifugal filter with risk group 2 and 3 bacteria. $B$. anthracis Sterne strain spores, $B$. anthracis NML strain spores, $F$. tularensis and $Y$. pestis vegetative bacteria were centrifuged with a $0.2 \mu \mathrm{m}$ filter in order to determine if the filter would effectively retain the bacteria. The filtrate was plated on appropriate media and incubated at $35^{\circ} \mathrm{C}$ for 2 weeks to check for growth. 
procedure was continued as described in the DNA IQ protocol for DNA extraction from solid materials. Remaining viable organism present in the eluted DNA sample was then determined by spread plating $10 \mu 1$ of sample onto TSA plates.

\section{Samples:}

\begin{tabular}{|l|l|c|c|c|}
\hline Name of Sample & Sample & Blood $(\boldsymbol{\mu l})$ & S. aureus $(\boldsymbol{\mu l})$ & Saline $(\boldsymbol{\mu l})$ \\
\hline SB5 & S. aureus + blood 5 & 5 & 150 & 95 \\
\hline SB10 & S. aureus + blood 10 & 10 & 150 & 90 \\
\hline SB25 & S. aureus + blood 25 & 25 & 150 & 75 \\
\hline SB50 & S. aureus + blood 50 & 50 & 150 & 50 \\
\hline SB75 & S. aureus + blood 75 & 75 & 150 & 25 \\
\hline B5 & Blood 5 & 5 & 0 & 245 \\
\hline B10 & Blood 10 & 10 & 0 & 240 \\
\hline B25 & Blood 25 & 25 & 0 & 225 \\
\hline B50 & Blood 50 & 50 & 0 & 200 \\
\hline B75 & Blood 75 & 0 & 0 & 175 \\
\hline S & S. aureus & & & 100 \\
\hline
\end{tabular}

All samples had no visible colonies when the DNA eluate was plated onto tryptic soy agar. Total DNA was determined using PicoGreen DNA Quantitation Kit and the Roche LightCycler.

The results for DNA quantification (Table 4) did not show any obvious trends. There wasn't an increase in concentration as the amount of blood increased and there also wasn't an increase in concentration when there was blood and bacteria mixed together. There was no significant difference between $0.2 \mu 1$ and $3.0 \mu l$ of blood; this could mean that there was sufficient DNA to saturate resin and anything above the saturation point would just wash away. The standard curve was linear but when dilutions of samples were used the results were not linear. A two fold dilution did not give a two fold decrease in fluorescence. 
Table 4: Concentration of human and $S$. aureus DNA determined using PicoGreen and Roche LightCycler fluorometer. Samples contained blood (B) or $S$. aureus mixed with blood (SB) or $S$. aureus alone (S). Lambda DNA was used as a DNA standard.

Samples were either undiluted or diluted 1:2.

\begin{tabular}{|l|c|c|l|c|c|}
\hline \multicolumn{1}{|c|}{ Sample } & $\begin{array}{c}\text { Amount of } \\
\text { blood }(\boldsymbol{\mu l})\end{array}$ & $\begin{array}{c}\text { Total DNA } \\
(\mathbf{n g})\end{array}$ & \multicolumn{1}{|c|}{ Sample } & $\begin{array}{c}\text { Amount of } \\
\text { blood }(\boldsymbol{\mu l})\end{array}$ & $\begin{array}{c}\text { Total DNA } \\
(\mathbf{n g})\end{array}$ \\
\hline SB 5 & 0.2 & 0.89 & B5 & 0.2 & 1.47 \\
\hline SB 5 (1:2) & 0.2 & 1.33 & B5 (1:2) & 0.2 & 1.13 \\
\hline SB10 & 0.5 & 0.64 & B10 & 0.5 & 1.29 \\
\hline SB10 (1:2) & 0.5 & 0.89 & B10 (1:2) & 0.5 & 1.78 \\
\hline SB25 & 1.0 & 1.82 & B25 & 1.0 & 1.79 \\
\hline SB25 (1:2) & 1.0 & 0.77 & B25 (1:2) & 1.0 & 2.34 \\
\hline SB50 & 2.0 & 0.81 & B50 & 2.0 & 0.59 \\
\hline SB50 (1:2) & 2.0 & 1.04 & B50 (1:2) & 2.0 & 0.89 \\
\hline SB75 & 3.0 & 0.92 & B75 & 3.0 & 0.92 \\
\hline SB75 (1:2) & 3.0 & 1.19 & B75 (1:2) & 3.0 & 0.98 \\
\hline S & 0 & 0.67 & S (1:2) & 0 & 1.54 \\
\hline
\end{tabular}


The human DNA was amplified using primers for short tandem repeats D18 and D3 along with the Roche LightCycler. $5 \mu$ l of DNA was used for each sample and the annealing temperature for PCR amplification was $56^{\circ} \mathrm{C}$ for $5 \mathrm{~s}$.

The crossing point $(\mathrm{Cp})$ is the cycle number where the amplification curve increases above the background noise. A lower $\mathrm{Cp}$ indicates a higher concentration of DNA present in the sample. The results for PCR (Table 5) did not work as expected; the human DNA did not always amplify at a crossing point lower than the negative or the samples with only bacteria. Changes to the PCR protocol need to be made such as lower annealing temperature and longer annealing times to optimize the amplification.

\section{DNA extraction of blood contaminated with $S$. aureus at $95^{\circ} \mathrm{C}$ for $30 \mathrm{~min}$ and $56^{\circ} \mathrm{C}$ overnight to be quantified and tested for DNA degradation}

The purpose of these experiments was to generate samples to test PicoGreen for DNA quantification and to test for degradation using primers for short tandem repeats D18 and D3 using real time PCR. Tests were also performed to determine if there were any changes in DNA concentration when a $0.2 \mu \mathrm{m}$ filter was used.

Test Disks: Whatman 3 cellulose filter paper disks were inoculated with of $S$. aureus (approx $10^{6}-10^{7} \mathrm{cfu} / \mathrm{sample}$ ) and anticoagulated (K $\mathrm{K}_{3}$ EDTA) human blood. The disks were immediately placed in eppendorf tubes without drying. Lysis was performed either at $95^{\circ} \mathrm{C}$ for 30 minutes or $56^{\circ} \mathrm{C}$ overnight. The contents of the tube were filtered by centrifugation using either a $0.2 \mu \mathrm{m}$ filter or a spin basket. Some samples were rinsed with $100 \mu l$ of lysis buffer without DTT. All samples were centrifuged again at high speed for $2 \mathrm{~min}$. The remainder of the procedure was continued as described in the DNA IQ 
Table 5 - Crossing point values of DNA from blood contaminated with bacteria, amplified with primers for STR D18 and D3. Samples contained blood only (B), blood mixed with $S$. aureus (SB) or $S$. aureus alone (S). DNA was amplified using primers for STRs with Roche LightCycler FastStart MasterPlus SYBR Green I kit.

\begin{tabular}{|l|c|l|c|}
\hline \multicolumn{1}{|c|}{ Sample } & Crossing Point & \multicolumn{1}{c|}{ Sample } & Crossing Point \\
\hline Human D18 & 20.82 & Human D3 & 24.10 \\
\hline Human D18 & 21 & Human D3 & 22.93 \\
\hline SB5 D18 & $>41$ & SB5 D3 & $>41$ \\
\hline SB5 D18 & 38.15 & SB5 D3 & $>41$ \\
\hline SB75 D18 & 31.04 & SB75 D3 & 33.24 \\
\hline SB75 D18 & 29.59 & SB75 D3 & 36.51 \\
\hline B5 D18 & $>41$ & B5 D3 & 36.84 \\
\hline B5 D18 & $>41$ & B5 D3 & 35.55 \\
\hline B75 D18 & $>41$ & B75 D3 & 36.73 \\
\hline B75 D18 & 37.35 & B75 D3 & 36.51 \\
\hline B75 (1:2) D18 & 34.15 & B75 (1:2) D3 & 35.70 \\
\hline S D18 & NR & S D3 & NR \\
\hline S D18 & NR & S D3 & NR \\
\hline Neg D18 & 35.66 & Neg D3 & 33.91 \\
\hline Neg D18 & $>41$ & Neg D3 & $>41$ \\
\hline NR
\end{tabular}

NR - no reaction 
protocol for DNA extraction from solid materials. Samples were eluted with $50 \mu \mathrm{l}$ of elution buffer. Samples were labelled as follows:

\begin{tabular}{|l|l|}
\hline B1 & Blood only, $0.2 \mu \mathrm{m}$ filter, no rinse \\
\hline B2-B4 & Blood only, $0.2 \mu \mathrm{m}$ filter, rinse \\
\hline B5 & Blood only, spin basket, rinse \\
\hline B6 & Blood only, 0.2 $\mu \mathrm{m}$ filter, rinse - plate all sample \\
\hline SB1 & Bacteria + blood, $0.2 \mu \mathrm{m}$ filter, no rinse \\
\hline SB2-SB4 & Bacteria + blood, $0.2 \mu \mathrm{m}$ filter, rinse \\
\hline SB5 & Bacteria + blood, spin basket, rinse \\
\hline SB6 & Bacteria + blood, $0.2 \mu \mathrm{m}$ filter, rinse - plate all sample \\
\hline S1-S3 & Bacteria only, $0.2 \mu \mathrm{m}$ filter, rinse \\
\hline S4 & Bacteria only, $0.2 \mu \mathrm{m}$ filter, rinse - plate all sample \\
\hline
\end{tabular}

All samples had no visible colonies when the DNA eluate was plated onto tryptic soy agar. No conclusions could be drawn about the changes in concentration of DNA with filter and without filter or with rinse and without rinse. There did appear to be a lower concentration of DNA when the samples were extracted at $56^{\circ} \mathrm{C}$ overnight compared to $95^{\circ} \mathrm{C}$ for $30 \mathrm{~min}$ (Table 6). For real time PCR, in most cases there did not appear to be a difference between samples that contained only blood and those that contained blood and bacteria (Tables 7,8). Most of the time samples with blood only or blood and bacteria amplified in fewer cycles than those with bacteria only. Samples generally amplified in fewer cycles than the blank sample. When comparing the crossing points of samples amplified with primers for STR D18 compared to STR D3, the crossing points for D3 were higher than D18. The gel electrophoresis confirmed that the D1 or D3 amplicon did amplify (Figure 5). All samples with blood only or blood and bacteria had a band for the appropriate short tandem repeat amplicon and it was at the appropriate base pair length. Samples that were a blank or were only bacteria did not have a band for the STR. 
Table 6: Concentration of human and $S$. aureus DNA determined using PicoGreen and Roche LightCycler fluorometer. Lysis was performed either at $95^{\circ} \mathrm{C}$ for $30 \mathrm{~min}$ or at $56^{\circ} \mathrm{C}$ overnight $(\mathrm{O} / \mathrm{N})$. Samples contained blood only (B), blood mixed with $S$. aureus (SB) or $S$. aureus alone (S)

\begin{tabular}{|l|c|c|c|c|}
\hline & \multicolumn{2}{|c|}{ Lysis 95 $^{\circ} \mathbf{C}, \mathbf{3 0 m i n}^{\prime}$} & \multicolumn{2}{c|}{ Lysis $\mathbf{5 6}^{\circ} \mathbf{C}, \mathbf{O} / \mathbf{N}$} \\
\hline Sample & $\begin{array}{c}\text { Total DNA } \\
\text { (ng) trial 1 }\end{array}$ & $\begin{array}{c}\text { Total DNA } \\
\text { (ng) trial 2 }\end{array}$ & $\begin{array}{c}\text { Total DNA } \\
\text { (ng) trial 1 }\end{array}$ & $\begin{array}{c}\text { Total DNA } \\
\text { (ng) trial 2 }\end{array}$ \\
\hline B1 & 8.57 & 3.51 & 2.59 & 2.43 \\
\hline B2 & 9.35 & 4.5 & 2.15 & 2.76 \\
\hline B5 & 6.85 & 6.35 & 2.15 & 4.22 \\
\hline SB1 & 9.13 & 6.27 & 2.35 & 4.33 \\
\hline SB2 & 7.29 & 4.50 & 2.35 & 4.50 \\
\hline SB5 & 8.74 & 5.66 & 2.97 & 6.86 \\
\hline S1 & 0 & 2.30 & 2.01 & 4.89 \\
\hline S2 & 7.04 & 2.60 & 1.80 & 6.69 \\
\hline
\end{tabular}


Table 7 - Crossing point values of DNA from blood contaminated with bacteria that was lysed at $95^{\circ} \mathrm{C}$ for $30 \mathrm{~min}$ and amplified with primers for STR D18 and D3.

Samples contained blood only (B), blood mixed with S. aureus (SB) or S. aureus alone (S). Samples were filtered with $0.2 \mu \mathrm{m}$ without rinsing (B1, SB1) or with rinse (B2-B4, SB2-SB4, S1-S3) or without filtering (B5, SB5). DNA was amplified using primers for STRs with Roche LightCycler FastStart MasterPlus SYBR Green I kit.

\begin{tabular}{|l|l|l|c|}
\hline \multicolumn{1}{|c|}{ Sample } & $\begin{array}{c}\text { Crossing } \\
\text { Point }\end{array}$ & \multicolumn{1}{|c|}{ Sample } & $\begin{array}{c}\text { Crossing } \\
\text { Point }\end{array}$ \\
\hline Human (1:5) D18 & 22.84 & Human (1:5) D3 & 23.00 \\
\hline Human (1:10) D18 & 23.28 & Human (1:10) D3 & 24.19 \\
\hline B2 D18 & 25.60 & B2 D3 & 26.64 \\
\hline B2 (1:2) D18 & 26.03 & B2 (1:2) D3 & 27.50 \\
\hline B5 D18 & 26.04 & B5 D3 & 26.94 \\
\hline B5 (1:2) D18 & 26.73 & B5 (1:2) D3 & 28.00 \\
\hline SB1 D18 & 25.18 & SB1 D3 & 26.43 \\
\hline SB1 (1:2) D18 & 25.94 & SB1(1:2) D3 & 27.52 \\
\hline SB2 D18 & 24.85 & SB2 D3 & 26.48 \\
\hline SB2 (1:2) D18 & 25.61 & SB2 (1:2) D3 & 26.95 \\
\hline SB5 D18 & 25.91 & SB5 D3 & N/A \\
\hline SB5 (1:2) D18 & 26.25 & SB5 (1:2) D3 & 27.72 \\
\hline S3 D18 & 32.22 & S3 D3 & 36.07 \\
\hline S3 (1:2) D18 & 33.08 & S3 (1:2)D3 & 35.43 \\
\hline Blank D18 & 33.51 & Blank D3 & 34.46 \\
\hline Blank D18 & 33.10 & Blank D3 & 34.96 \\
\hline
\end{tabular}


Table 8 - Crossing point values of DNA from blood contaminated with bacteria that was lysed at $56^{\circ} \mathrm{C}$ for $30 \mathrm{~min}$ and amplified with primers for STR D18 and D3.

Samples contained blood only (B), blood mixed with $S$. aureus (SB) or S. aureus alone (S). Samples were filtered with $0.2 \mu \mathrm{m}$ without rinsing (B1, SB1) or with rinse (B2-B4, SB2-SB4, S1-S3) or without filtering (B5, SB5). DNA was amplified using primers for STRs with Roche LightCycler FastStart MasterPlus SYBR Green I kit.

\begin{tabular}{|l|l|l|l|}
\hline \multicolumn{1}{|c|}{ Sample } & $\begin{array}{c}\text { Crossing } \\
\text { Point }\end{array}$ & \multicolumn{1}{|c|}{ Sample } & $\begin{array}{c}\text { Crossing } \\
\text { Point }\end{array}$ \\
\hline Human (1:5) D18 & 22.65 & Human (1:5) D3 & 24.13 \\
\hline Human (1:10) D18 & 22.54 & Human (1:10) D3 & 23.53 \\
\hline B1 (1:2) D18 & 27.43 & B1 (1:2) D3 & 27.98 \\
\hline B1 (1:2) D18 & 27.94 & B1 (1:2) D3 & 28.70 \\
\hline B5 (1:2) D18 & 27.57 & B5 (1:2) D3 & 28.18 \\
\hline B5 (1:2) D18 & 27.27 & B5 (1:2) D3 & 28.22 \\
\hline SB1 (1:2) D18 & 27.65 & SB1 (1:2) D3 & 28.45 \\
\hline SB1 (1:2) D18 & 27.53 & SB1(1:2) D3 & 28.45 \\
\hline SB2 (1:2) D18 & 27.68 & SB2 (1:2) D3 & 28.62 \\
\hline SB2 (1:2) D18 & 27.56 & SB2 (1:2) D3 & 28.71 \\
\hline SB5 (1:2) D18 & 30.66 & SB5 (1:2) D3 & 30.09 \\
\hline SB5 (1:2) D18 & 30.70 & SB5 (1:2) D3 & 29.97 \\
\hline S1 (1:2) D18 & 32.14 & S1 (1:2) D3 & 34.42 \\
\hline S1 (1:2) D18 & 32.57 & S1 (1:2)D3 & 34.87 \\
\hline Blank D18 & 33.21 & Blank D3 & 34.50 \\
\hline Blank D18 & 33.41 & Blank D3 & 32.56 \\
\hline
\end{tabular}



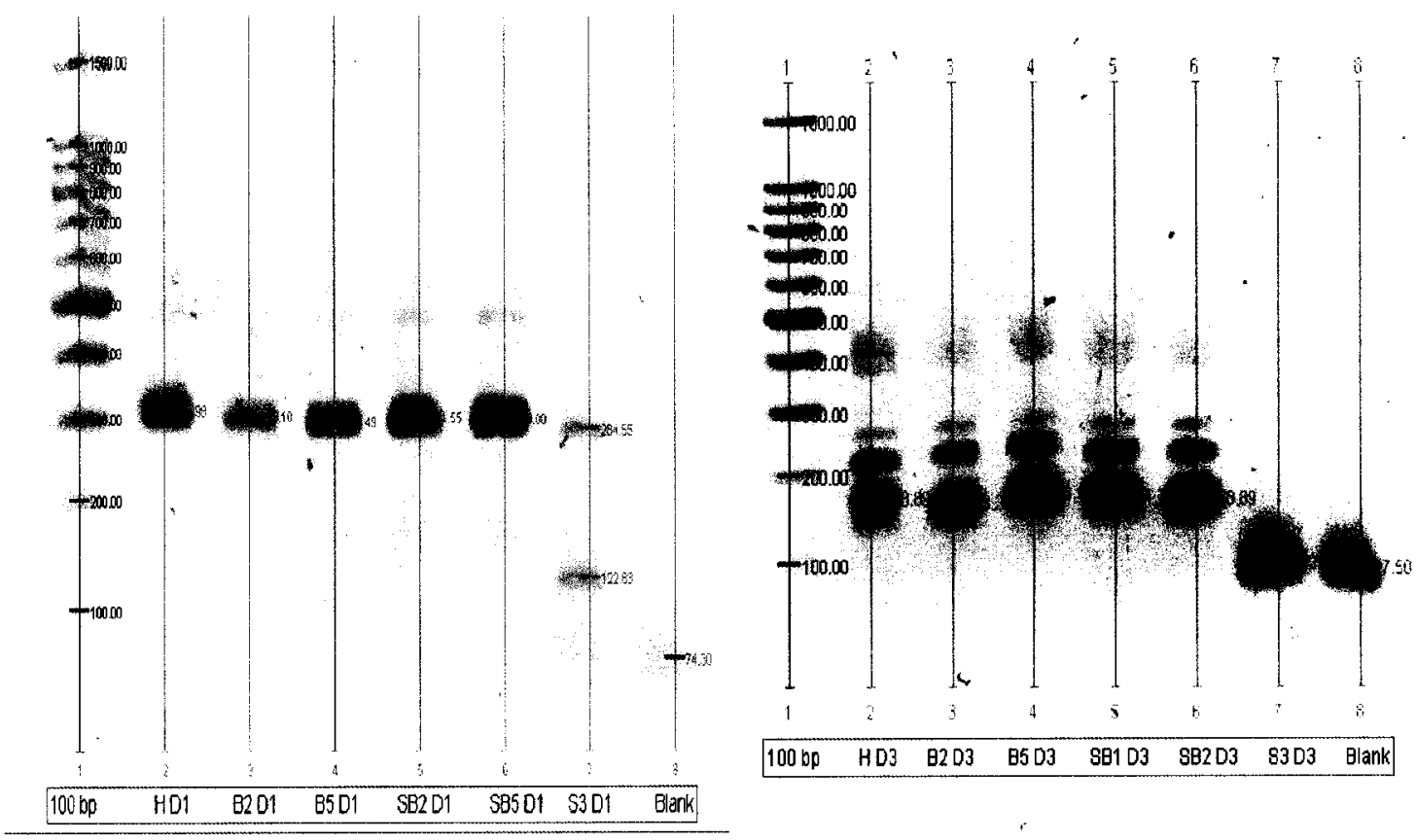

Figure 5 - Gel electrophoresis of DNA from blood contaminated with $S$. aureus and amplified with primers for either STR D18 or D3. A $2 \%$ agarose gel was run at $70 \mathrm{~V}$ for $75 \mathrm{~min}$. Samples included human DNA STD (H), blood (B) and $S$. aureus (S). Primers used in real time PCR with LightCycler FastStart MasterPlus SYBR Green I Kit were D18 (262bp-342bp) on the left gel and D3 (99-147bp) on the right gel. 


\section{DNA Extraction and quantification of varying amounts of blood}

The purpose of these experiments was to use different amounts of blood to see if the increasing amounts of DNA saturated the resin. The DNA extraction was performed according to the procedure from Promega DNA IQ protocol. Blood was added straight to the tube without filter paper and without bacteria. Sample amounts were $1 \mu 1,50 \mu 1,100 \mu 1$ and $150 \mu \mathrm{l}$ and all volumes were made up with saline. $200 \mu \mathrm{l}$ of lysis buffer with DTT was added to each sample which were heated at $95^{\circ} \mathrm{C}$ for $30 \mathrm{~min}$. Samples after lysis were separated into 3 vials, $100 \mu 1$ each. Samples were centrifuged with either a $0.2 \mu \mathrm{m}$ filter or without a filter. Samples were either rinsed and centrifuged with $200 \mu$ l lysis buffer or $200 \mu \mathrm{l}$ of lysis buffer was added directly to the tube. For human DNA quantification the Promega AluQuant Human DNA Quantitation kit was used according the manufacturer's protocol. Samples were added to Luciferin all at the same time and the values were read on a luminometer.

Values were higher than expected for $1 \mu 1$, although samples should have been mixed one at a time and then read. Results indicated that there was less DNA recovered when a filter was used but only when there was a large amount of blood used. It was found that during the experiment, samples with large amounts of blood did not filter through the $0.2 \mu \mathrm{m}$ filter very well, there was still some blood left behind. It appeared that rinsing the filter and then centrifuging again improved the recovery of DNA. It also appeared that the resin was eventually saturated (probably between $1 \mu \mathrm{l}$ and $50 \mu \mathrm{l}$ ) since there was no large increase in DNA when the amount of blood was increased. This may have also been due to clogging of the filter. 
Table 9 - Quantification of DNA from varying amounts of human blood extracted with Promega DNA IQ system and quantified using Promega AluQuant DNA Quantitation System. Samples were run in duplicate.

\begin{tabular}{|l|c|c|c|c|c|c|c|c|}
\hline & \multicolumn{9}{|c|}{ Total DNA in blood (ng) } \\
\hline & \multicolumn{2}{|c|}{ 1 $\boldsymbol{\mu l}$} & \multicolumn{2}{c|}{$\mathbf{5 0} \boldsymbol{\mu l}$} & \multicolumn{2}{c|}{$\mathbf{1 0 0} \boldsymbol{\mu l}$} & \multicolumn{2}{c|}{$\mathbf{1 5 0 \mu l}$} \\
\hline Filter & 28.4 & 25.6 & 53.8 & 55.8 & 34.2 & 33.2 & 25.0 & 25.6 \\
\hline Filter and Rinse & 30.6 & 30.8 & 60.8 & 64.6 & 36.6 & 38.6 & 27.6 & 27.8 \\
\hline No Filter & 29.8 & 40.0 & 183 & 68.4 & 50.8 & 88.8 & 75.6 & 87.8 \\
\hline
\end{tabular}




\section{DNA Quantification by two Methods: Promega AluQuant and Molecular Probes PicoGreen}

DNA was quantified using both PicoGreen and Promega AluQuant to compare the differences between a non-specific method of quantification and a human specific method. Blood mixed with bacteria were added to filter paper disks and were incubated at $56^{\circ} \mathrm{C}$ overnight. The samples were centrifuged with a $0.2 \mu \mathrm{m}$ filter and rinsed with $200 \mu \mathrm{l}$ of lysis buffer without DTT. The tubes were centrifuged after the wash with lysis buffer because there was liquid remaining in the lid after vortexing. DNA was eluted with $50 \mu \mathrm{l}$ of elution buffer.

Human specific DNA quantification was performed using Promega AluQuant Human DNA Quantitation kit according to the manufacturer's protocol. Samples were mixed with luciferin and read one at a time on the luminometer. For non- specific DNA quantification Molecular Probes PicoGreen kit was used according to the manufacturer's protocol and lambda DNA was used as a standard. Samples were read one at a time using the Roche LightCycler fluorometer. In order to determine if the DNA was amplifiable the Roche LightCycler FastStart DNA MasterPlus SYBR Green I kit was used. Primers for STRs D18 and D3 were used in the same reaction mix so that more samples could be analyzed in less time. Samples were left undiluted for real time PCR amplification. DNA Quantification using AluQuant (Table 10): It was found that values for DNA concentration were not consistent and repeats were not always reproducible. DNA concentrations were a bit lower than the expected amount of DNA for $1 \mu 1$ (15ng-25ng). Some samples had a negative value for DNA concentration since the luminescence reading for sample with probe was lower than the reading without the probe. The probe 
Table 10 - Total amount of human DNA from blood contaminated with Staphylococcus aureus quantified using Promega AluQuant. Samples were extracted using Promega DNA IQ system at $56^{\circ} \mathrm{C} \mathrm{O} / \mathrm{N}$ and quantified using Promega AluQuant Human DNA Quantitation System and the Turner Biosystems 20/20n luminometer. Samples were run in duplicate.

\begin{tabular}{|l|c|c|c|c|c|c|}
\hline \multicolumn{1}{|c|}{ Samples } & \multicolumn{5}{c|}{ Total Human DNA (ng) } \\
\hline & \multicolumn{2}{|c|}{ Trial 1 } & \multicolumn{2}{c|}{ Trial 2 } & \multicolumn{2}{c|}{ Trial 3 } \\
\hline Female subject & 9.4 & neg & 9.4 & 4.4 & 8.0 & 9.1 \\
\hline Female subject + S. aureus & 7.1 & neg & 7.4 & neg & 11.7 & neg \\
\hline Male subject & 4.9 & 11.7 & 5.2 & 12.3 & 16.0 & 18.5 \\
\hline Male subject + S. aureus & 6.0 & neg & 8.3 & 10.6 & 17.6 & 14.3 \\
\hline S. aureus & 2.9 & 2.6 & 2.7 & 2.6 & 4.2 & 4.2 \\
\hline
\end{tabular}


used was human specific therefore there should not have be an increase or decrease in luminescence when bacteria were added. Also, there should not have been any reaction for the bacterial DNA samples. The values for bacterial DNA were lower than those with human DNA but there was still a reaction. The method was found to be very time consuming and there were many manipulations and incubation steps compared to other methods. There were many steps where errors could be made and not all samples gave a positive value for DNA concentration.

DNA Quantification using PicoGreen (Table 11): Values were much lower than those obtained using AluQuant kit and also much lower than expected values (15-25ng). There was an increase in amount of DNA when bacteria were added to the blood, which would be expected since the PicoGreen dye is non-specific. There was also a larger amount of DNA in blood from the male subject compared to blood from the female subject which could be due to differences in gender.

DNA Amplification (Table 12): All human DNA samples were amplifiable and there did not appear to be any differences in crossing points for samples with bacteria or without. The samples containing DNA from blood amplified in fewer cycles (lower crossing point) than samples with only bacteria or only water. This was to be expected since the primers were human specific.

Gel Electrophoresis (Figure 6): Amplicons for both short tandem repeats were visible on the gel. The darkest bands did have a base pair number close to the expected amplicon sizes for the short tandem repeats. The bacteria only samples had bands similar to the STRs although they were slightly lower in base pairs. There may have been some nonspecific binding of the primers to the DNA, although this would have taken place much 
Table 11 - Total amount of DNA from blood contaminated with Staphylococcus aureus quantified using PicoGreen. Samples were extracted using Promega DNA IQ system at $56^{\circ} \mathrm{C}$ O/N and quantified using Molecular Probes PicoGreen DNA Quantitation kit with the Roche LightCycler fluorometer. Samples were run in duplicate.

\begin{tabular}{|l|c|c|}
\hline \multicolumn{1}{|c|}{ Sample } & \multicolumn{2}{c|}{ Total DNA (ng) } \\
\hline Female subject & 0.9 & 0.6 \\
\hline Female subject + S. aureus & 1.4 & 1.6 \\
\hline Male subject & 2.2 & 0.4 \\
\hline Male subject + S. aureus & 2.1 & 2.6 \\
\hline S. aureus & 4.8 & 0.2 \\
\hline
\end{tabular}


Table 12 - Crossing point values of female and male human DNA contaminated with $S$. aureus that were amplified using primers for short tandem repeats D18 and D3 in a multiplex reaction. DNA was lysed at $56^{\circ} \mathrm{C}$ for $30 \mathrm{~min}$ and extracted using Promega DNA IQ system. DNA was amplified using primers for STRs with Roche LightCycler FastStart MasterPlus SYBR Green I kit.

\begin{tabular}{|l|c|c|}
\hline \multicolumn{1}{|c|}{ Sample } & $\begin{array}{c}\text { Crossing Point } \\
\text { Trial 1 }\end{array}$ & $\begin{array}{c}\text { Crossing Point } \\
\text { Trial 2 }\end{array}$ \\
\hline Human STD (1:5) & 21.02 & 20.74 \\
\hline Human STD (1:5) & 21.17 & 20.60 \\
\hline Female subject & 24.74 & 24.60 \\
\hline Female subject & 24.43 & 23.95 \\
\hline Female subject + S. aureus & 24.94 & 23.97 \\
\hline Female subject + S. aureus & 24.69 & 23.59 \\
\hline Male subject & 24.26 & 29.19 \\
\hline Male subject & 24.83 & 23.67 \\
\hline Male subject + S. aureus & 24.28 & 23.78 \\
\hline Male subject + S. aureus & 23.82 & 23.08 \\
\hline S. aureus & 31.21 & 31.68 \\
\hline S. aureus & 31.53 & 30.26 \\
\hline Blank & 31.55 & 31.19 \\
\hline Blank & 31.31 & 31.62 \\
\hline
\end{tabular}




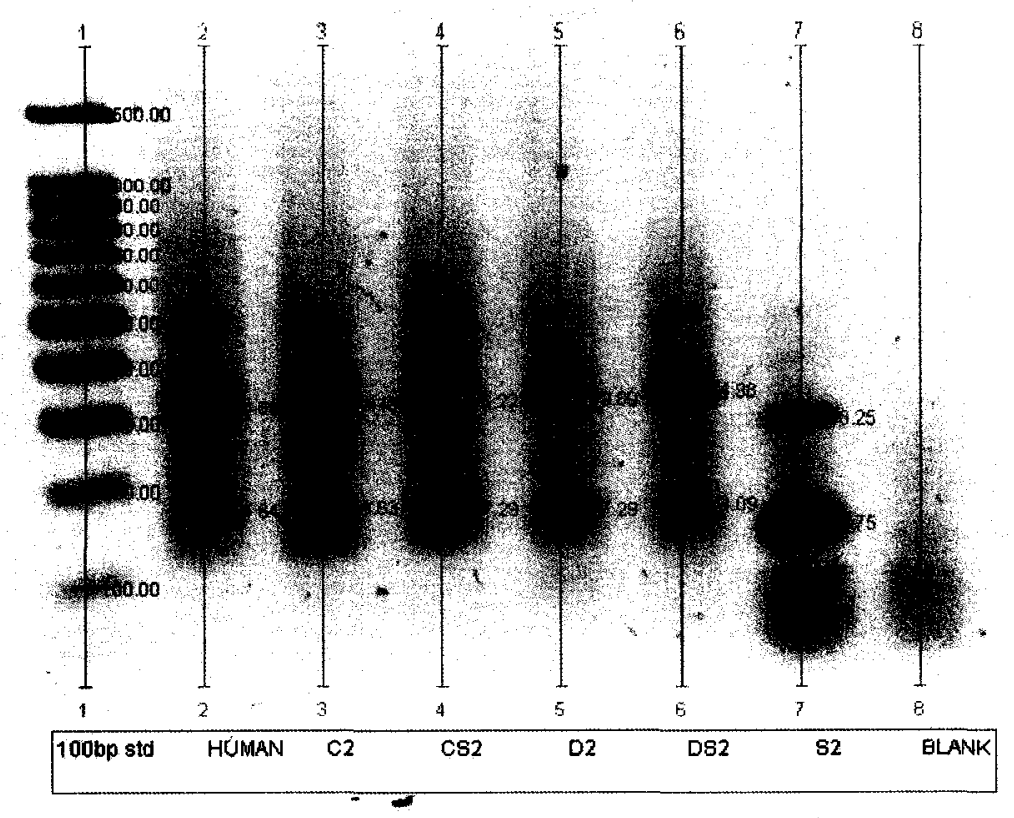

Figure 6 - Gel electrophoresis of DNA from blood contaminated with $S$. aureus and amplified with primers STR D18 and D3 in a multiplex reaction. A 2\% agarose gel was run at $70 \mathrm{~V}$ for $75 \mathrm{~min}$. Samples included a human DNA STD, blood from female subject (C), blood from male subject (D) and $S$. aureus (S). Primers used in real time PCR with LightCycler FastStart MasterPlus SYBR Green I Kit were D18 (262bp-342bp) and D3 (99-147bp). 
later in the PCR reaction because the samples amplified much later than the human samples. Also, there may have been human DNA contamination in the bacteria only samples. There were no bands present in the negative sample (water).

\section{Extraction, quantification and amplification of blood contaminated with risk group}

\section{1 and 2 vegetative bacteria}

In order to determine the effect of bacteria contaminating human samples, $1 \mu$ of blood was mixed with $100 \mu \mathrm{l}$ of bacteria $\left(10^{5}-10^{6} /\right.$ sample) or with $100 \mu \mathrm{l}$ of concentrated bacteria $\left(10^{7}-10^{8} / \mathrm{sample}\right)$. Lysis was performed at $56^{\circ} \mathrm{C}$ overnight and samples were filtered with $0.2 \mu \mathrm{m}$ filter after lysis. The remainder of the extraction was carried out following modified DNA IQ protocols. A portion of the sample ( $5 \mu 1$ or $10 \%)$ was spread plated on TSA to check for growth. Samples were quantified using Promega AluQuant DNA Quantitation on a luminometer and were amplified/quantified using primers for short tandem repeats on the Roche LightCycler. Samples were also quantified using the Quantifiler on an ABI Prism 7000 Sequence Detection System and amplified using the AmpFISTR Profiler plus on a thermal cycler and the amplicons were run on the ABI Genetic analyzer. This was performed by James Elliot at the RCMP in Ottawa.

The quantity of DNA was similar using all three different quantification methods, except for DNA with S. aureus quantified using Promega AluQuant. Some of the values were much higher than the results obtained using the other kits (Tables 13-15). Promega AluQuant kit will no longer be used because the method was time consuming and there were many chances for error in pipetting. The results were sometimes inconsistent and the duplicates were not very precise. All samples were able to amplify using the Roche 
Table 13 - Quantification of DNA using Promega AluQuant on a luminometer, Roche LightCycler FastStart MasterPlus SYBR Green I kit and Quantifiler on an ABI Prism Sequence Detection System. Samples include human blood and S. aureus. Samples were run in duplicate for AluQuant and SYBR Green and averages are shown for each sample.

\begin{tabular}{|l|r|r|r|}
\hline \multicolumn{1}{|c|}{ Sample } & $\begin{array}{r}\text { DNA (ng) } \\
\text { AluQuant }\end{array}$ & $\begin{array}{c}\text { DNA (ng) } \\
\text { SYBR Green }\end{array}$ & $\begin{array}{c}\text { DNA (ng) } \\
\text { Quantifiler }\end{array}$ \\
\hline Female subject & 13.80 & 4.18 & 3.83 \\
\hline Female subject + S. aureus & 12.54 & 4.06 & 12.65 \\
\hline Female subject + S. aureus $x 100$ & 5.80 & 3.52 & $\mathbf{8 . 8 5}$ \\
\hline S. aureus & 0 & 0.09 & 0 \\
\hline Male subject & 19.72 & 5.43 & 9.65 \\
\hline Male subject + S. aureus & 17.22 & 5.48 & 7.45 \\
\hline Male subject + S. aureus $\times 100$ & 10.83 & 6.40 & 7.20 \\
\hline Female subject & 26.03 & 3.31 & 4.19 \\
\hline Female subject + S. aureus & 51.28 & 3.23 & 8.85 \\
\hline Female subject + S. aureus $x 100$ & 64.95 & 3.30 & 6.55 \\
\hline S. aureus & 0 & 0.36 & 0 \\
\hline Male subject & 32.37 & 3.67 & 8.30 \\
\hline Male subject + S. aureus & $\mathrm{n} / \mathbf{a}$ & 3.89 & 7.80 \\
\hline Male subject + S. aureus $\mathrm{x} 100$ & 68.29 & 1.9 & 6.85 \\
\hline
\end{tabular}


Table 14 - Quantification of DNA using Promega AluQuant on a luminometer, Roche LightCycler FastStart MasterPlus SYBR Green I kit and Quantifiler on an ABI Prism Sequence Detection System. Samples include human blood and $P$. aeruginosa. Samples were run in duplicate for AluQuant and SYBR Green and averages are shown for each sample.

\begin{tabular}{|c|c|c|c|}
\hline Sample & $\begin{array}{l}\text { DNA (ng) } \\
\text { AluQuant }\end{array}$ & $\begin{array}{c}\text { DNA (ng) } \\
\text { SYBR Green }\end{array}$ & $\begin{array}{c}\text { DNA (ng) } \\
\text { Quantifiler }\end{array}$ \\
\hline Female subject & 8.87 & 5.71 & 4.08 \\
\hline Female subject $+P$. aeruginosa & 13.92 & 7.41 & 5.25 \\
\hline Female subject $+P$. aeruginosa $\times 100$ & 5.49 & 3.49 & 5.80 \\
\hline P. aeruginosa & 0 & 0.62 & $\overline{0}$ \\
\hline Male subject & 5.96 & 2.55 & 8.25 \\
\hline Male subject $+P$. aeruginosa & 15.34 & 6.65 & 2.80 \\
\hline Male subject $+P$. aeruginos $a \times 100$ & 11.46 & 6.93 & 5.20 \\
\hline Female subject & 8.62 & 6.38 & 5.75 \\
\hline Female subject $+P$. aeruginosa & 5.74 & 6.37 & 10.2 \\
\hline Female subject $+P$. aeruginosa $\times 100$ & 3.49 & 2.25 & 5.10 \\
\hline P. aeruginosa & 1.26 & 0.38 & 0 \\
\hline Male subject & 6.02 & 5.09 & 7.40 \\
\hline Male subject $+P$. aeruginosa & 9.80 & 6.25 & 8.40 \\
\hline Male subject $+P$. aeruginosa $\times 100$ & 4.22 & 2.71 & 34.25 \\
\hline
\end{tabular}


Table 15 - Quantification of DNA using Promega AluQuant on a luminometer, Roche LightCycler FastStart MasterPlus SYBR Green I kit and Quantifiler on an ABI Prism Sequence Detection System. Samples include human blood and B. subtilis. Samples were run in duplicate for AluQuant and SYBR Green and averages are shown for each sample.

\begin{tabular}{|l|r|r|r|}
\hline \multicolumn{1}{|c|}{ Sample } & $\begin{array}{c}\text { DNA (ng) } \\
\text { AluQuant }\end{array}$ & $\begin{array}{c}\text { DNA (ng) } \\
\text { SYBR Green }\end{array}$ & $\begin{array}{c}\text { DNA (ng) } \\
\text { Quantifiler }\end{array}$ \\
\hline Female subject & & & 5.55 \\
\hline Female subject + B. subtilis & 7.97 & 4.61 & 6.90 \\
\hline Female subject + B. subtilis $\times 100$ & 3.33 & 6.14 & 7.25 \\
\hline B. subtilis & 9.03 & 6.28 & 0 \\
\hline Male subject & 0 & 0.97 & 5.50 \\
\hline Male subject + B. subtilis & 9.88 & 7.85 & 5.90 \\
\hline Male subject + B. subtilis $\times 100$ & 5.95 & 6.48 & 11.20 \\
\hline Female subject & 9.77 & 5.87 & 4.46 \\
\hline Female subject + B. subtilis & 5.59 & 5.31 & 4.11 \\
\hline Female subject + B. subtilis $\times 100$ & 2.56 & 10.67 & 6.20 \\
\hline B. subtilis & 2.62 & 5.00 & 0 \\
\hline Male subject & 0 & 0.17 & 2.87 \\
\hline Male subject + B. subtilis & 8.15 & 7.99 & 5.40 \\
\hline Male subject + B. subtilis $\times 100$ & 3.88 & 10.16 & 6.05 \\
\hline
\end{tabular}


LightCycler and all samples that included blood amplified before the negative samples and before the samples that contained bacteria only (results not shown).

Some degradation was seen using Profiler Plus used by RCMP. All samples (with bacteria and without) showed some loci imbalance that may have been due to degradation or inhibition. Inhibition was ruled out since the internal control gave good results.

Degradation occurred in alleles that were larger in size. Degradation was demonstrated by differences in peak intensity. Samples that were older showed more degradation. This could be due to degradation related to storage or inexperience with the DNA extraction technique at the start of the project. Two samples, both from female subject's blood, without bacteria had some of the higher loci missing. One sample from male subject's blood with $P$. aeruginosa gave only a partial profile. Even though degradation occurred, all samples except for one, yielded a useable profile. It is important to note that the presence or absence of bacteria in a sample did not appear to impact degradation.

\section{DNA Extraction, Quantification and Amplification of various types of samples from a crime scene}

The purpose of the following experiments was to determine the amount of DNA that can be recovered from various sample types. All samples were processed as previously described. DNA was amplified and quantified using Roche LightCycler. Gum: There was still a small amount of liquid left behind in some samples after filtration. Gum that was added to filter and centrifuged clogged the filter and therefore results could not be shown for those samples. When gum was centrifuged using a spin basket the gum went through the basket in strings and was too difficult to work with. 
Table 16 - DNA Extracted from various sample types, quantified and amplified using Roche LightCycler.

\begin{tabular}{|l|c|}
\hline \multicolumn{1}{|c|}{ Sample } & $\begin{array}{c}\text { Total Human } \\
\text { DNA (ng) }\end{array}$ \\
\hline Gum & 14.78 \\
\hline Gum & 15.19 \\
\hline Gum & 20.72 \\
\hline Gum & 0.13 \\
\hline swab from pencil & 0.24 \\
\hline swab from Styrofoam cup & 12.33 \\
\hline swab from Styrofoam cup & 4.70 \\
\hline Buccal swab & 331.25 \\
\hline Buccal swab & 384.50 \\
\hline hair & 89.55 \\
\hline hair & 59.15 \\
\hline cigarette cut up 250 $\mu 1$ & 3.62 \\
\hline cigarette cut up 500 $\mu 1$ & 9.08 \\
\hline cigarette with extra paper $250 \mu 1$ & 0.13 \\
\hline cigarette with extra paper $500 \mu l$ & 0.06 \\
\hline cigarette cut in half $250 \mu 1$ & 7.73 \\
\hline cigarette cut in half $500 \mu 1$ & 0.18 \\
\hline
\end{tabular}


Therefore, only the liquid remaining after lysis was used for the remaining samples and the piece of gum was discarded.

Swab from pencil: There was not a usable amount of DNA recovered from swabbing a pencil that had been handled.

Buccal swab: There was more than enough DNA obtained from buccal swabs.

Hair: There was a large amount of DNA obtained from hair, although the root was still attached which is a large source of DNA.

Cigarettes: The amount of DNA from cigarettes was low, therefore different volumes of lysis buffer and different amounts of paper were used. The volume (Table 16) refers to amount of stain extraction buffer used for lysis. Cigarettes were cut in half and one piece was used for each volume. The differences in amount of DNA recovered could also be due to differences in skin cells on the cigarette filter. Also, some parts of cigarette butt may have had more lip contact than others or one cigarette may have had more than another.

\section{Extraction, quantification and amplification of gum, hair and cigarettes contaminated with risk group 1 and 2 vegetative bacteria} Various sample types: DNA was extracted from hair, gum and cigarettes following the same method as for blood. Sample was filtered by centrifugation after lysis and $5 \mu 1$ of sample was cultured to check for growth.

Total DNA varied from sample to sample (Table 17-20) for all sample types. This was expected since it was impossible to obtain the same amount of skin cells or saliva from different samples. The amount of DNA extracted from gum varied from 0.46 ng to 
20.90ng for samples quantified using SYBR Green and they varied from $3.3 \mathrm{ng}$ to $8.6 \mathrm{ng}$ for samples quantified with Quantifiler (Table 17). There was a higher quantity of DNA obtained from hair roots and values ranged from $0.87 \mathrm{ng}$ to $179.90 \mathrm{ng}$ with SYBR Green and 0.75 ng to 260.5 for Quantifiler (Table 18).

There was a problem quantifying DNA from cigarettes using the SYBR Green with the Roche LightCycler (Table 19). Samples with only bacteria were amplifying even though the primers were human specific. Samples quantified using Quantifiler did not show these same results. Samples with $P$. aeruginosa demonstrated the most problems, which may have been caused by sample contamination or non-specific binding of primer. Even samples with human DNA mixed with $P$. aeruginosa had higher than normal amounts of human DNA, although this could be due to sample to sample variation. The quantity of DNA from cigarettes varied from $0.27 \mathrm{ng}$ to $50.70 \mathrm{ng}$ with SYBR Green and $0.13 \mathrm{ng}$ to $39.35 \mathrm{ng}$ for Quantifiler. Most of the cigarette samples had too little DNA for human DNA profiling.

Swabs from latex gloves did not obtain high amounts of DNA (Table 20). The range of DNA was $0.40 \mathrm{ng}$ to $7.99 \mathrm{ng}$ for SYBR Green, although there were still problems with bacterial DNA amplifying. With Quantifiler the range was $0.09 \mathrm{ng}$ to $0.61 \mathrm{ng}$. The values obtained from the LightCycler kit were very comparable to results using DNA Quantifiler. All samples from gum, hair, cigarettes and swabs from latex gloves were able to be amplified using primers for short tandem repeats D18 and D3. 
Table 17 - Total amount of human DNA (ng) from chewing gum contaminated with risk group 1 or 2 bacteria. DNA was quantified using quantitative real time PCR with the Roche LightCycler FastStart MasterPlus SYBR Green I kit and with the Quantifiler Human DNA Quantification Kit in the ABI Prism 7000 Sequence Detection System, Samples were run in duplicate for SYBR Green and averages are shown for each sample.

\begin{tabular}{|c|c|c|c|}
\hline Sample & $\begin{array}{c}\text { DNA (ng) } \\
\text { SYBR Green } 1\end{array}$ & $\begin{array}{c}\text { DNA (ng) } \\
\text { SYBR Green } 2 \\
\end{array}$ & $\begin{array}{l}\text { DNA (ng) } \\
\text { Quantifiler }\end{array}$ \\
\hline Female subject & 0.59 & 6.17 & 8.35 \\
\hline Male subject & 0.46 & 0.70 & 4.32 \\
\hline Female subject $+S$. aureus & 5.33 & 6.25 & 8.60 \\
\hline Male subject $+S$. aureus & 1.43 & 6.28 & 4.38 \\
\hline $\begin{array}{l}\text { Female subject }+ \text { S. aureus } \\
\text { 100x }\end{array}$ & 3.87 & 4.78 & 4.94 \\
\hline Male subject $+S$. aureus $100 \mathrm{x}$ & 1.76 & 8.80 & 3.30 \\
\hline S. aureus & 0.09 & 0.11 & \\
\hline S. aureus 100x & 0.25 & 0.44 & 0.00 \\
\hline Female subject & 5.72 & 6.62 & \\
\hline Male subject & 14.57 & 4.35 & \\
\hline Female subject $+P$. aeruginosa & 0.88 & 18.74 & \\
\hline Male subject $+P$. aeruginosa & 1.80 & 9.85 & \\
\hline $\begin{array}{l}\text { Female subject }+P . \text { aeruginosa } \\
100 \mathrm{x}\end{array}$ & 10.41 & 19.56 & \\
\hline $\begin{array}{l}\text { Male subject }+P . \text { aeruginosa } \\
\text { 100x }\end{array}$ & 1.33 & 4.48 & \\
\hline P. aeruginosa & 0.27 & 0.34 & \\
\hline P. aeruginosa 100x & 0.88 & 1.02 & \\
\hline Female subject & 20.84 & 10.22 & \\
\hline Male subject & 5.10 & 9.24 & \\
\hline Female subject $+B$. subtilis & 6.09 & 9.31 & \\
\hline Male subject $+B$. subtilis & 20.90 & 11.85 & \\
\hline $\begin{array}{l}\text { Female subject }+B \text {. subtilis } \\
100 x\end{array}$ & 8.44 & 8.22 & \\
\hline Male subject $+B$. subtilis $100 \mathrm{x}$ & 18.52 & 10.99 & \\
\hline B. subtilis & 0.12 & 0.18 & \\
\hline B. subtilis 100x & 1.79 & 0.13 & \\
\hline
\end{tabular}


Table 18 - Total amount of human DNA from human hair roots contaminated with risk group 1 and risk group 2 bacteria. DNA was quantified using quantitative real time PCR with the Roche LightCycler FastStart MasterPlus SYBR Green I kit and with the Quantifiler Human DNA Quantification Kit in the ABI Prism 7000 Sequence Detection System. Samples were run in duplicate for SYBR Green and averages are shown for each sample.

\begin{tabular}{|l|r|r|r|}
\hline \multicolumn{1}{|c|}{ Sample } & \multicolumn{1}{c|}{$\begin{array}{c}\text { DNA (ng) } \\
\text { SYBR Green 1 }\end{array}$} & $\begin{array}{c}\text { DNA (ng) } \\
\text { SYBR Green 2 }\end{array}$ & $\begin{array}{c}\text { DNA (ng) } \\
\text { Quantifiler }\end{array}$ \\
\hline Female subject & 54.22 & 60.13 & \\
\hline Male subject & 54.38 & 43.76 & \\
\hline Female subject + S. aureus & 4.09 & 53.16 & \\
\hline Male subject + S. aureus & 107.75 & 0.87 & \\
\hline Female subject + S. aureus 100x & 17.57 & 4.55 & \\
\hline Male subject + S. aureus 100x & 14.08 & 38.78 & \\
\hline S. aureus & 0.22 & 0.07 & \\
\hline S. aureus 100x & 0.75 & 0.13 & \\
\hline Female subject & 21.63 & 66.98 & 2.57 \\
\hline Male subject & 126.63 & 98.13 & 88.00 \\
\hline Female subject + P. aeruginosa & 73.78 & 2.05 & 14.15 \\
\hline Male subject + P. aeruginosa & 179.90 & 48.30 & 122.00 \\
\hline Female subject + P. aeruginosa & & & \\
100x & 20.88 & 21.03 & 0.75 \\
\hline Male subject + P. aeruginosa 100x & 29.44 & 15.77 & 15.65 \\
\hline P. aeruginosa & 0.87 & 0.88 & 0 \\
\hline P. aeruginosa 100x & 5.00 & 2.53 & 0 \\
\hline Female subject & 2.07 & 23.96 & 2.63 \\
\hline Male subject & 74.63 & 26.47 & 119.50 \\
\hline Female subject + B. subtilis & 4.44 & 12.12 & 4.23 \\
\hline Male subject + B. subtilis & 2.06 & 14.43 & 69.50 \\
\hline Female subject + B. subtilis 100x & 13.72 & 10.23 & 12.45 \\
\hline Male subject + B. subtilis 100x & 1.85 & 30.83 & 260.50 \\
\hline B. subtilis & 0.10 & 0.22 & \\
\hline B. subtilis 100x & 0.36 & 1.04 & 0 \\
\hline
\end{tabular}


Table 19 - Total amount of DNA in cigarette butts contaminated with risk group 1 and risk group 2 bacteria. DNA was quantified using quantitative real time PCR with the Roche LightCycler FastStart MasterPlus SYBR Green I kit and with the Quantifiler Human DNA Quantification Kit in the ABI Prism 7000 Sequence Detection System.

Samples were run in duplicate for SYBR Green and averages are shown for each sample.

\begin{tabular}{|l|c|c|c|c|}
\hline \multicolumn{1}{|c|}{ Sample } & $\begin{array}{c}\text { DNA (ng) } \\
\text { SYBR } \\
\text { Green 1 }\end{array}$ & $\begin{array}{c}\text { DNA (ng) } \\
\text { SYBR } \\
\text { Green 2 }\end{array}$ & $\begin{array}{c}\text { DNA (ng) } \\
\text { SYBR } \\
\text { Green 3 }\end{array}$ & $\begin{array}{c}\text { DNA (ng) } \\
\text { Quantifiler }\end{array}$ \\
\hline Female subject & 0.37 & 0.31 & 1.66 & 0.13 \\
\hline Male subject & 0.27 & 14.96 & 0.56 & 0.64 \\
\hline Female subject + S. aureus & 9.07 & 10.94 & & \\
\hline Male subject + S. aureus & 4.65 & 13.07 & & \\
\hline Female subject + P. aeruginosa & 5.18 & 35.23 & & 4.80 \\
\hline Male subject $+\boldsymbol{P}$. aeruginosa & 39.21 & 50.70 & & 39.35 \\
\hline Female subject + B. subtilis & 11.05 & 12.32 & & \\
\hline Male subject + B. subtilis & 5.65 & $\mathrm{n} / \mathrm{a}$ & & \\
\hline S. aureus & 3.58 & 1.41 & & \\
\hline $\boldsymbol{P}$ aeruginosa & 3.70 & 24.04 & & 0.00 \\
\hline B. subtilis & 1.07 & 0.91 & & \\
\hline
\end{tabular}


Table 20 - Total amount of DNA in epithelial cells from latex gloves contaminated with risk group 1 and risk group 2 bacteria. DNA was quantified using quantitative real time PCR with the Roche LightCycler FastStart MasterPlus SYBR Green I kit and with the Quantifiler Human DNA Quantification Kit in the ABI Prism 7000 Sequence Detection System. Samples were run in duplicate for SYBR Green and averages are shown for each sample.

\begin{tabular}{|l|c|c|}
\hline \multicolumn{1}{|c|}{ Sample } & $\begin{array}{c}\text { DNA (ng) } \\
\text { SYBR Green I }\end{array}$ & $\begin{array}{c}\text { DNA (ng) } \\
\text { Quantifiler }\end{array}$ \\
\hline Female subject & 0.40 & 0.09 \\
\hline Male subject & 0.69 & 0.48 \\
\hline Female subject + S. aureus 100x & 6.41 & \\
\hline Male subject + S. aureus 100x & 0.35 & \\
\hline Female subject + P. aeruginosa 100x & 7.99 & 0 \\
\hline Male subject + P. aeruginosa 100x & 3.45 & 0.61 \\
\hline S. aureus & 2.37 & \\
\hline P. aeruginosa & 18.14 & 0 \\
\hline
\end{tabular}




\section{Effect of filtration on DNA yield}

Experiments were run to determine the effect on the quantity of DNA due to the filtration step after lysis at $56^{\circ} \mathrm{C}$ for $30 \mathrm{~min}$. Human blood $(1 \mu \mathrm{l}$ in $100 \mu$ l of saline) was used as a source of DNA. Five samples were filtered in a centrifuge at 10,000xg for $2 \mathrm{~min}$, while five samples were centrifuged without a filter. There did not appear to be a difference in quantity of DNA, therefore it does not seem as though filtering has an effect on the amount of DNA recovered from samples (Table 21). The mean value for DNA that was filtered was $25.80+/-11.94 \mathrm{ng}$ and the mean value for DNA that was not filtered was $24.35+/-14.98 \mathrm{ng}$. There was too much variation between samples to make any conclusions about the effect of the filter on DNA yield. The extraction blank contained saline and was used to ensure that none of the extraction reagents were contaminated with human DNA. The melting points were used to check for DNA purity and to ensure that both STRs were amplified. Not all samples had a melting peak around $79^{\circ} \mathrm{C}$, including the human DNA standard, although all samples had a melting peak around $84^{\circ} \mathrm{C}$.

\section{Extraction/Amplification/Quantification of blood filtered after lysis vs. after elution}

Originally samples were filtered after lysis but changes were made to the protocol for samples contaminated with risk group 3 bacteria. The filtration step was moved to after elution so that the filtration was the final step in the extraction. This would ensure that the sample wouldn't become recontaminated due to contamination in the lab. Experiments were performed to demonstrate the difference in quantity of DNA for samples that were filtered either after lysis compared to after elution. Human blood $(1 \mu 1$ in $100 \mu$ l of saline) was used as a DNA source and samples were lysed at $56^{\circ} \mathrm{C}$ for $30 \mathrm{~min}$. 
Table 21 - Comparison of filtration vs. no filtration of human blood DNA samples extracted with Promega DNA IQ kit. DNA was amplified using quantitative real time PCR with the Roche LightCycler FastStart MasterPlus SYBR Green I kit with primers for STRs D18 and D3 in the same reaction.

\begin{tabular}{|l|r|r|r|}
\hline \multicolumn{1}{|c|}{ Sample } & $\begin{array}{c}\text { Total } \\
\text { DNA (ng) }\end{array}$ & $\begin{array}{c}\text { Melting } \\
\text { Peak 1 }\end{array}$ & $\begin{array}{c}\text { Melting } \\
\text { Peak 2 }\end{array}$ \\
\hline & & & \\
\hline 0.25 ng STD & 0.26 & & 84.35 \\
\hline 0.25 ng STD & 0.24 & & 84.27 \\
\hline Filter 1 & 9.10 & 78.70 & 84.06 \\
\hline Filter 2 & 28.00 & 78.99 & 84.15 \\
\hline Filter 3 & 20.15 & 78.88 & 84.12 \\
\hline Filter 4 & 30.80 & 78.88 & 84.18 \\
\hline Filter 5 & 40.95 & 79.02 & 84.14 \\
\hline No Filter 1 & 48.20 & 79.10 & 84.31 \\
\hline No Filter 2 & 28.75 & 79.07 & 84.14 \\
\hline No Filter 3 & 10.60 & & 84.19 \\
\hline No Filter 4 & 19.90 & 78.97 & 84.26 \\
\hline No Filter 5 & 14.30 & 78.71 & 84.20 \\
\hline Extraction Blank 1 & Neg & 78.09 & \\
\hline Extraction Blank 2 & Neg & 78.41 & 83.31 \\
\hline Blank & Neg & 77.60 & 83.23 \\
\hline Blank & 1.29 & 79.21 & \\
\hline
\end{tabular}


Half of the samples were filtered in a centrifuge at $10,000 \mathrm{xg}$ for $2 \mathrm{~min}$ after lysis and the others were filtered after elution. Although quantities vary from sample to sample, it appears as though more DNA is lost to the filter when the sample is filtered after lysis (mean value: $13.7 \mathrm{ng}+/-3.0 \mathrm{ng}$ ) than after elution (mean value:. $23.4 \mathrm{ng}+/-10.7 \mathrm{ng}$ ) (Table 22). Every sample contained two melting peaks between $78-79^{\circ} \mathrm{C}$ and between $83-$ $84^{\circ} \mathrm{C}$. Human DNA standards did not contain a peak at the lower temperature.

\section{DNA Amplification and Quantification of human blood contaminated with risk group 3 bacteria}

DNA was extracted from human blood contaminated with either B. anthracis spores, $Y$. pestis or F. tularensis. DNA was extracted from a total of 112 samples; 36 of those samples were entirely plated onto the appropriate media and the remaining 76 samples had half of the sample plated onto media to ensure that the $0.2 \mu \mathrm{m}$ filter basket removed all remaining bacteria after elution. To demonstrate that bacteria were retained by the filter, $100 \mu$ l of PBS was added to a used $0.2 \mu \mathrm{m}$ filter. The liquid was pipetted up and down and plated onto appropriate media and incubated. One filter was tested per bacteria type. Filters used for $Y$. pestis and $F$. tularensis were negative for growth, which indicates that these bacteria were lysed by lysis buffer or heat or was removed by the washing. Colonies from the $B$. anthracis filter were too numerous to count which indicates that the anthrax spores were not lysed and were trapped by the $0.2 \mu \mathrm{m}$ filer.

Following a 2 week incubation period, all of the 112 DNA filtrate samples were negative for growth and were then removed from the CL3 laboratory following proper 
Table 22 - Comparison of human DNA from blood filtered after lysis or after elution. DNA was amplified using quantitative real time PCR with the Roche LightCycler FastStart MasterPlus SYBR Green I kit with primers for STRs D18 and D3 in the same reaction.

\begin{tabular}{|l|r|r|r|}
\hline \multicolumn{1}{|c|}{ Sample } & $\begin{array}{c}\text { Total } \\
\text { DNA (ng) }\end{array}$ & $\begin{array}{c}\text { Melting } \\
\text { Peak 1 }\end{array}$ & $\begin{array}{c}\text { Melting } \\
\text { Peak 2 }\end{array}$ \\
\hline & & & \\
\hline 0.25ng STD & 0.26 & & 84.35 \\
\hline 0.25ng STD & 0.24 & & 84.27 \\
\hline Lysis 1 & 11.15 & 78.05 & 83.91 \\
\hline Lysis 2 & 18.60 & 78.77 & 84.15 \\
\hline Lysis 3 & 10.85 & 78.73 & 83.90 \\
\hline Lysis 4 & 16.05 & 78.89 & 83.98 \\
\hline Lysis 5 & 10.70 & 78.53 & 83.95 \\
\hline Lysis 6 & 14.95 & 78.58 & 84.10 \\
\hline Elution 1 & 22.95 & 78.85 & 83.91 \\
\hline Elution 2 & 12.55 & 78.46 & 83.76 \\
\hline Elution 3 & 19.70 & 78.69 & 84.02 \\
\hline Elution 4 & 14.70 & 78.76 & 83.89 \\
\hline Elution 5 & 45.10 & 78.92 & 84.14 \\
\hline Elution 6 & 25.45 & 78.88 & 84.00 \\
\hline Blank & neg & 77.60 & 83.23 \\
\hline Blank & 1.29 & 79.21 & \\
\hline
\end{tabular}


procedures. Some of the samples were used for quantification and amplification of STR D18 and D3 and others were sent to the RCMP for quantification and DNA profiling.

The quantification results vary between samples, which could possibly be due to variability in the number of white blood cells in the different samples. Quantification was performed to have an estimate of total DNA in each sample and also to ensure that enough DNA was present to obtain a DNA profile. Only Ing of DNA is needed to perform a DNA profile, therefore there was plenty of DNA present in all of the samples. In some of the experiments DNA from bacteria only, specifically $Y$. pestis and F. tularensis amplified even though the primers are designed to amplify human STRs. This may be due to non-specific binding of the primers due to non-optimal annealing temperatures for both sets of primers, or due to primer dimmers or non-specific binding of the SYBR Green dye. All samples had amplifiable DNA, which indicated that the samples were not compromised due to either the filtration or the contaminating bacterial DNA. Melting points were used to determine if one STR was amplified and not the other. In most samples there was a larger peak around $85^{\circ} \mathrm{C}$, which was within one or two degrees of the standard sample. The larger peak should correspond to the larger amplicon, STR D18 (262-342bp). In some samples there was no smaller melting peak, at around $80^{\circ} \mathrm{C}$, which should correspond to the smaller amplicon STR D3 (99-147bp). This happened more often than not, for samples with bacteria present. Although, the reason for this may be the non-optimal annealing temperature for D3 primers which have a melting point of $55^{\circ} \mathrm{C}$ and $58^{\circ} \mathrm{C}$, the annealing temperature used was $55^{\circ} \mathrm{C}$, and for these primers it should have been between $50-53^{\circ} \mathrm{C}$. If there was DNA degradation present, it would be expected that the larger STR, D18 would have been degraded first, which was not the 
Table 23 - Quantification and amplification of STRs D18 and D3 from human blood samples contaminated with risk group 3 bacteria using quantitative real time PCR with Roche LightCycler FastStart DNA MasterPlus SYBR Green I. Samples were run in duplicate. Trial 1.

\begin{tabular}{|c|c|c|c|}
\hline Sample & $\begin{array}{c}\text { Total DNA } \\
\text { (ng) }\end{array}$ & $\begin{array}{c}\text { Melting } \\
\text { Peak 1 } \\
\end{array}$ & $\begin{array}{c}\text { Melting } \\
\text { Peak 2 } \\
\end{array}$ \\
\hline 0.375 ng DNA STD & 0.41 & 79.50 & 85.09 \\
\hline 0.375 ng DNA STD & 0.35 & 79.71 & 85.18 \\
\hline Female subject & 25.02 & 79.77 & 85.19 \\
\hline Female subject & 32.74 & & 85.29 \\
\hline Female subject $+B$. anthracis & 25.31 & & 85.01 \\
\hline Female subject $+B$. anthracis & 22.83 & & 85.00 \\
\hline Female subject $+Y$. pestis & 32.77 & & 86.43 \\
\hline Female subject $+Y$. pestis & 23.66 & & 86.31 \\
\hline Female subject $+F$. tularensis & 12.68 & & 85.25 \\
\hline Female subject $+F$. tularensis & 12.95 & & 84.93 \\
\hline Male subject & 54.65 & 79.54 & 85.19 \\
\hline Male subject & 64.58 & 79.48 & 84.89 \\
\hline Male subject $+B$. anthracis & 16.78 & & 85.24 \\
\hline Male subject $+B$. anthracis & 16.30 & & 84.92 \\
\hline Male subject $+Y$. pestis & 12.08 & 80.18 & 84.73 \\
\hline Male subject $+Y$. pestis & 11.59 & 79.32 & 84.65 \\
\hline Male subject $+F$. tularensis & 41.06 & & 86.36 \\
\hline Male subject $+F$.tularensis & 40.01 & & 86.39 \\
\hline B. anthracis & neg & $\mathrm{n} / \mathrm{a}$ & $\mathrm{n} / \mathrm{a}$ \\
\hline B. anthracis & neg & 76.78 & 82.88 \\
\hline$Y$. pestis & neg & 78.77 & \\
\hline$Y$. pestis & neg & 80.43 & \\
\hline$F$.tularensis & 36.26 & & 86.25 \\
\hline F. tularensis & 39.03 & & 86.32 \\
\hline Blank & neg & 77.36 & \\
\hline Blank & neg & 78.76 & 84.53 \\
\hline
\end{tabular}


Table 24 - Quantification and amplification of STRs D18 and D3 from human blood samples contaminated with risk group 3 bacteria using quantitative real time PCR with Roche LightCycler FastStart DNA MasterPlus SYBR Green I.. Samples were run in duplicate. Trial 2.

\begin{tabular}{|l|r|r|r|}
\hline \multicolumn{1}{|c|}{ Sample } & $\begin{array}{c}\text { Total DNA } \\
\text { (ng) }\end{array}$ & $\begin{array}{c}\text { Melting } \\
\text { Peak 1 }\end{array}$ & $\begin{array}{c}\text { Melting } \\
\text { Peak 2 }\end{array}$ \\
\hline 0.1875ng DNA STD & & & 85.36 \\
\hline 0.1875ng DNA STD & 0.19 & 78.81 & 85.13 \\
\hline Female subject & 29.57 & 79.68 & 85.15 \\
\hline Female subject & 54.26 & 79.65 & 85.16 \\
\hline Female subject + B. anthracis & 38.63 & 79.52 & 85.02 \\
\hline Female subject + B. anthracis & 51.33 & 79.99 & 85.29 \\
\hline Female subject + Y. pestis & 82.04 & & 86.46 \\
\hline Female subject + Y. pestis & 51.91 & & 86.42 \\
\hline Female subject + F. tularensis & 17.07 & 79.51 & 84.98 \\
\hline Female subject + F. tularensis & 13.86 & 79.47 & 84.99 \\
\hline Male subject & 51.66 & 79.64 & 85.11 \\
\hline Male subject & 51.77 & 79.59 & 85.1 \\
\hline Male subject + B. anthracis & 19.48 & 80.32 & 85.39 \\
\hline Male subject + B. anthracis & 16.75 & 79.84 & 85.36 \\
\hline Male subject $+Y$. pestis & 28.95 & & 86.36 \\
\hline Male subject + Y. pestis & 28.37 & & 86.38 \\
\hline Male subject + F. tularensis & 14.46 & & 85.12 \\
\hline Male subject + F. tularensis & 21.50 & 79.65 & 84.89 \\
\hline B. anthracis & neg & & 82.24 \\
\hline B. anthracis & 7.50 & & 81.95 \\
\hline Y. pestis & 31.64 & & 86.38 \\
\hline Y. pestis & 19.52 & & 86.26 \\
\hline F. tularensis & 2.60 & & 82.69 \\
\hline F. tularensis & 1.79 & & 84.06 \\
\hline Blank & neg & 78.91 & 84.23 \\
\hline Blank & & 78.73 & \\
\hline
\end{tabular}


Table 25 - Quantification and amplification of STRs D18 and D3 from human blood samples contaminated with risk group 3 bacteria using quantitative real time PCR with Roche LightCycler FastStart DNA MasterPlus SYBR Green I. Samples were run in duplicate. Trial 3.

\begin{tabular}{|c|c|c|c|}
\hline Sample & $\begin{array}{c}\text { Total DNA } \\
\text { (ng) }\end{array}$ & $\begin{array}{c}\text { Melting } \\
\text { Peak 1 } \\
\end{array}$ & $\begin{array}{c}\text { Melting } \\
\text { Peak } 2 \\
\end{array}$ \\
\hline $0.25 n g$ DNA STD & 0.258 & 80.08 & 85.64 \\
\hline $0.25 \mathrm{ng}$ DNA STD & 0.242 & 79.78 & 85.65 \\
\hline Female subject $+Y$. pestis & 92.295 & & 86.99 \\
\hline Female subject $+Y$. pestis & 90.825 & & 87.01 \\
\hline Female subject $+F$. tularensis & 11.445 & & 85.88 \\
\hline Female subject $+F$. tularensis & 11.235 & & 85.97 \\
\hline Male subject $+Y$. pestis & 137.55 & & 86.94 \\
\hline Male subject $+Y$. pestis & 139.65 & & 86.88 \\
\hline Male subject $+F$. tularensis & 13.44 & & 85.78 \\
\hline Male subject $+F$. tularensis & 12.495 & & 85.81 \\
\hline$Y$. pestis & 190.05 & & 86.85 \\
\hline$Y$.pestis & 138.6 & & 86.79 \\
\hline F.tularensis & neg & 80.7 & 84.95 \\
\hline F. tularensis & neg & & \\
\hline Blank & neg & 78.24 & \\
\hline Blank & neg & 80.47 & 85.11 \\
\hline
\end{tabular}


case. There was also a shift in melting peak temperature for blood with $Y$. pestis or $Y$. pestis on its own. The shift resulted in a higher melting peak above $86^{\circ} \mathrm{C}$. Human DNA profiles will give a better indication whether or not DNA was degraded or if there was any interference from the bacteria.

An example of a standard curve that was used to quantify DNA with the Roche LightCycler FastStart MasterPlus SYBR Green I kit is shown in Figure 7. The standard used was Human Genomic DNA from Promega AluQuant kit. An example of an amplification curve of RG3 bacteria contaminating blood is shown in Figure 8 .

\section{Biothreat Screening}

Once DNA has been extracted from samples from a crime scene that has been contaminated with biothreat agents, it can be used to serve two different purposes. Not only can the DNA be used to give a human DNA profile, it can also be used to determine the type of biothreat agent since the vegetative bacterial cells have also been lysed by the lysis buffer and heat. To demonstrate that the DNA samples can be used to verify the type of bacteria used in a bioterrorist attack or accidental release, the DNA samples were analysed using a Biothreat screening kit (Idaho Technologies Inc, Salt Lake City, Utah) and run on the LightCycler (Roche). DNA extracts from blood samples mixed with level 3 bacteria were tested.

Results indicated that the DNA samples could also be used to detect bacterial DNA (Table 26). The samples that contained bacterial DNA tested positive for either B. anthracis, $Y$. pestis or F. tularensis. For most samples DNA amplified at a crossing 


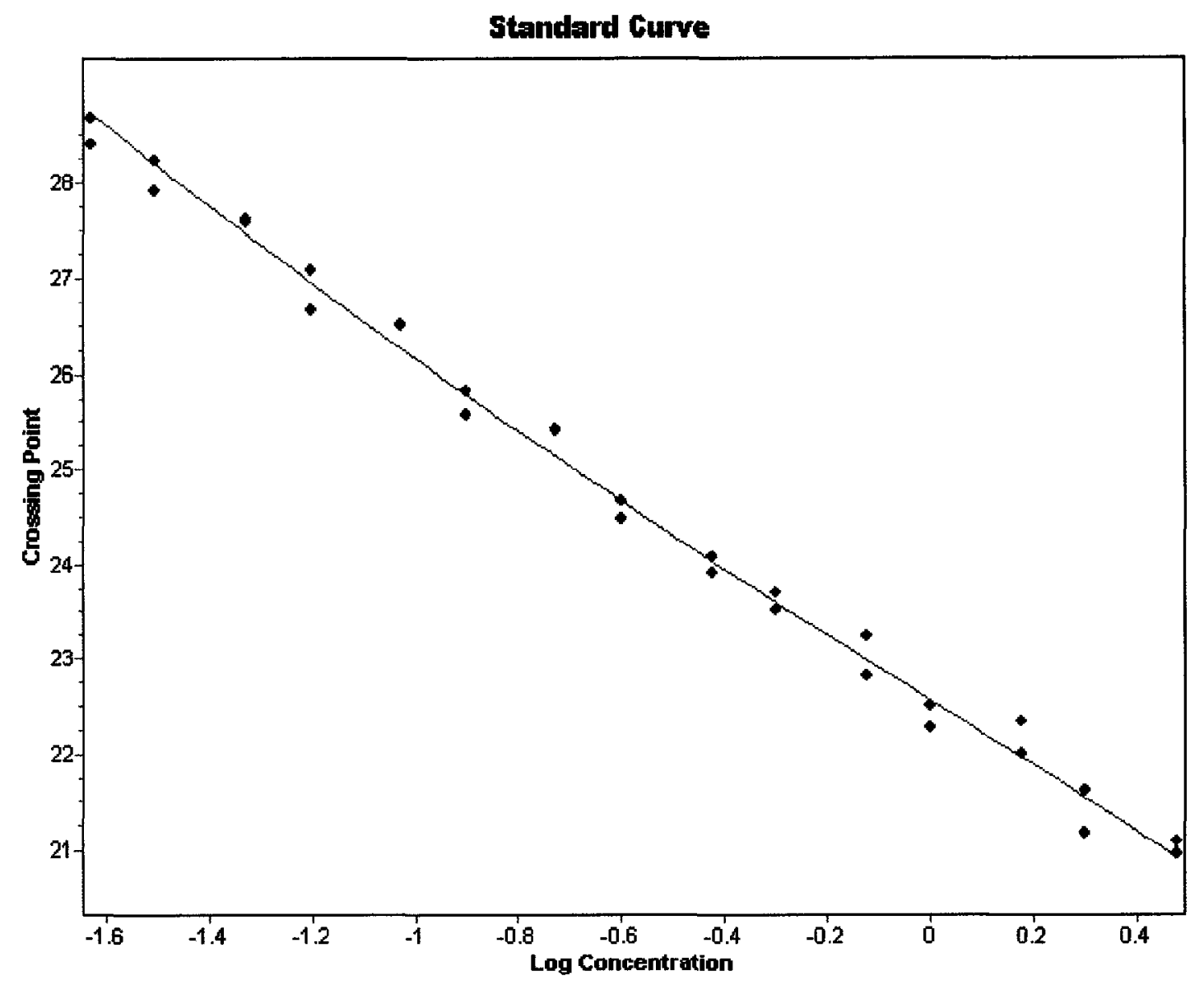

Error: 0.00987

Efficiency: 1.966

Figure 7: DNA standard curve using human genomic DNA standard from Promega AluQuant kit. DNA was amplified and quantified using primers for STR D18 and D3 with Roche LightCycler FastStart MasterPlus SYBR Green I 


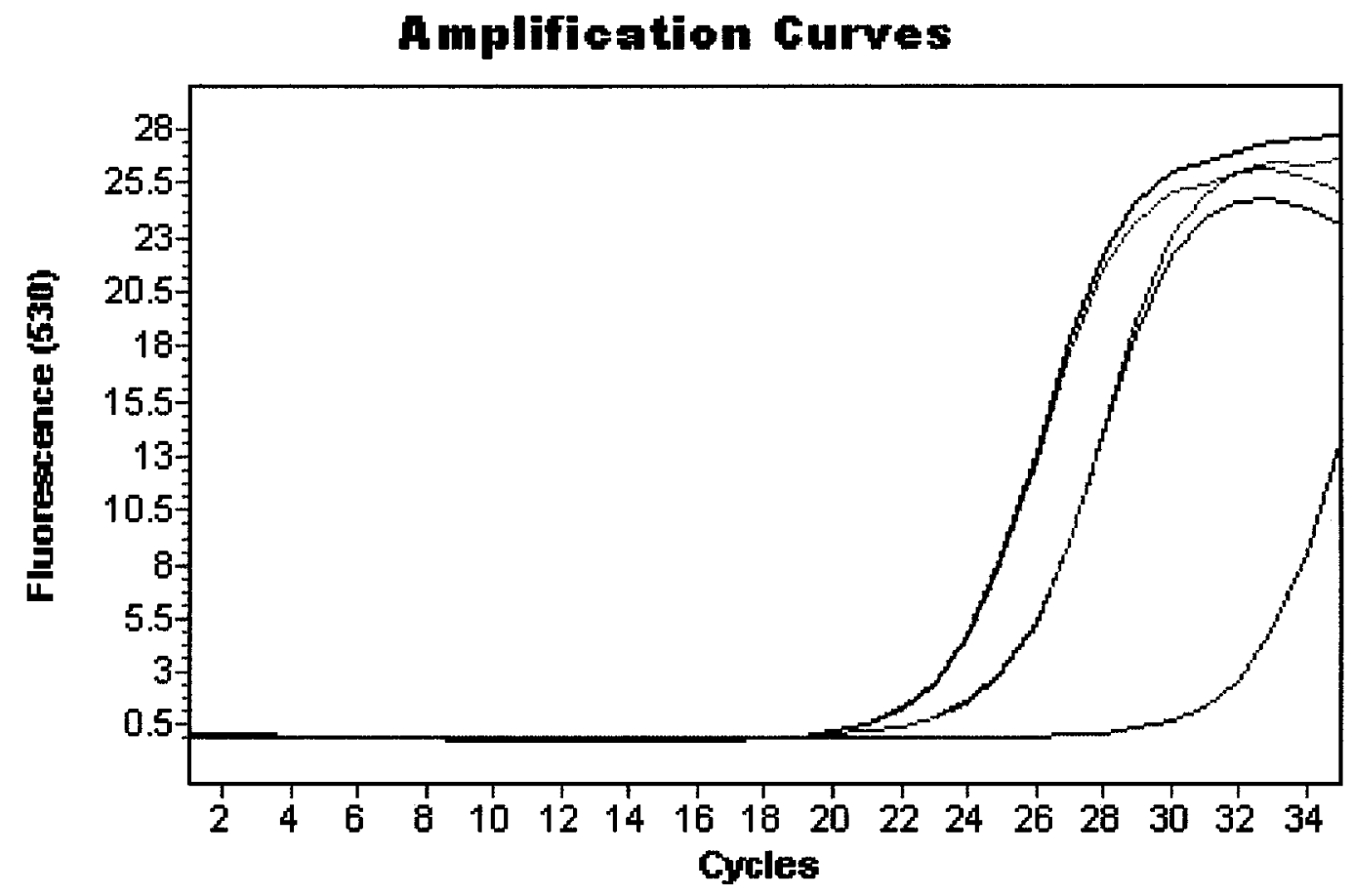

Figure 8 - Example of an amplification curve using primers for STR D18 and D3 with Roche LightCycler FastStart MasterPlus SYBR Green I. Samples in order of increasing crossing point, (samples done in duplicate): Female blood with $Y$. pestis, $0.25 \mathrm{ng} / \mu 1$ standard and blank. 
Table 26 - Testing of DNA from human blood contaminated with risk group 3 samples with a Biothreat Screening kit with the Roche LightCycler

\begin{tabular}{|l|r|}
\hline \multicolumn{1}{|c|}{ Sample } & Crossing Point \\
\hline Testing for Anthrax & \\
\hline Anthrax positive control & 21.5 \\
\hline Anthrax negative control & negative \\
\hline Female subject & negative \\
\hline $\begin{array}{l}\text { Female subject }+ \text { B. } \\
\text { anthracis }\end{array}$ & 19.97 \\
\hline Male subject + B. anthracis & 26.05 \\
\hline B. anthracis & 20.10 \\
\hline Testing for $Y \cdot$ pestis & 19.36 \\
\hline Yersinia positive control & negative \\
\hline Yersinia negative control & 18.93 \\
\hline Female subject $+Y$. pestis & 19.84 \\
\hline Male subject $+Y$. pestis & 17.79 \\
\hline Female subject $+Y$. pestis & 18.20 \\
\hline Male subject $+Y$. pestis & \\
\hline Testing for $\boldsymbol{F}$. tularensis & 20.96 \\
\hline Tularensis positive control & negative \\
\hline Tularensis negative control & 19.87 \\
\hline $\begin{array}{l}\text { Female subject }+F . \\
\text { tularensis }\end{array}$ & 19.85 \\
\hline Male subject $+F$. tularensis & 20.69 \\
\hline $\begin{array}{l}\text { Female subject }+F . \\
\text { tularensis }\end{array}$ & 19.62 \\
\hline Male subject $+F$. tularensis & \\
\hline
\end{tabular}


point close to the crossing point of the positive sample. Only one sample had a crossing point that was high (Male subject $+B$. anthracis), although it was still considered positive. There may have been less vegetative bacteria in this sample which would give less bacterial DNA to detect. The one sample that only contained human DNA and no bacterial DNA tested negative for $B$. anthracis as expected.

\section{DNA Typing}

To determine if any DNA degradation occurred it was important to look at the differences in intensity between the smallest STR and the largest STR. The larger STRs are more susceptible to DNA degradation and normally have lower fluorescence intensities. The difference in fluorescence intensity between samples is only indicative of the amount of DNA present and not the quality of the DNA.

For blood samples mixed with risk group 1 and 2 bacteria, most samples showed DNA degradation, although a DNA profile was still obtainable (Figures $9 \& 10$ ). Degradation also occurred in samples with blood only, therefore it cannot be concluded that the presence of bacteria was responsible for the degradation of the human DNA in mixed samples. When comparing the differences in intensity between D3 and D18 (Figures $9 \& 10$, Tables $27 \& 28$ ) it cannot be concluded that bacteria had an effect on the degradation of DNA since all samples showed some level of degradation, including the control. There were many samples that had a large amount of degradation, these samples were mostly older samples and the degradation may be due to age of sample or the inexperience of the operator at the technique. The samples seemed to get better with time. One sample type that appeared to cause more degradation was concentrated amounts of B. subtilis vegetative bacteria. 
For the samples from gum, hair and cigarettes the bacteria does not seem to have an effect on the quality of DNA, although there was no control sample for the cigarettes since there was insufficient amounts of DNA for the control (Figure 11, Table 29). Out of 19 samples, 16 had full DNA profiles, 2 had partial profiles (Female donor cigarette with concentrated $P$. aeruginosa and Male donor's gum control) and 1 with no profile (Female donor's gum with concentrated S. aureus).

Blood that was contaminated with risk group 3 bacteria gave the best results, with very little DNA degradation, except for the control samples for the second trial (Figure 12, Table 30). The difference between these DNA extractions and the ones with RG1 and RG2 bacteria is the time when the filtration step was introduced. For the RG1 and RG2 bacteria the filtration step was right after lysis when the DNA is still attached to protein and is not purified, the DNA may be susceptible to shearing at this point. For the RG3 bacteria the filtration step was added after DNA elution when the DNA is purified, which may filter more easily. 


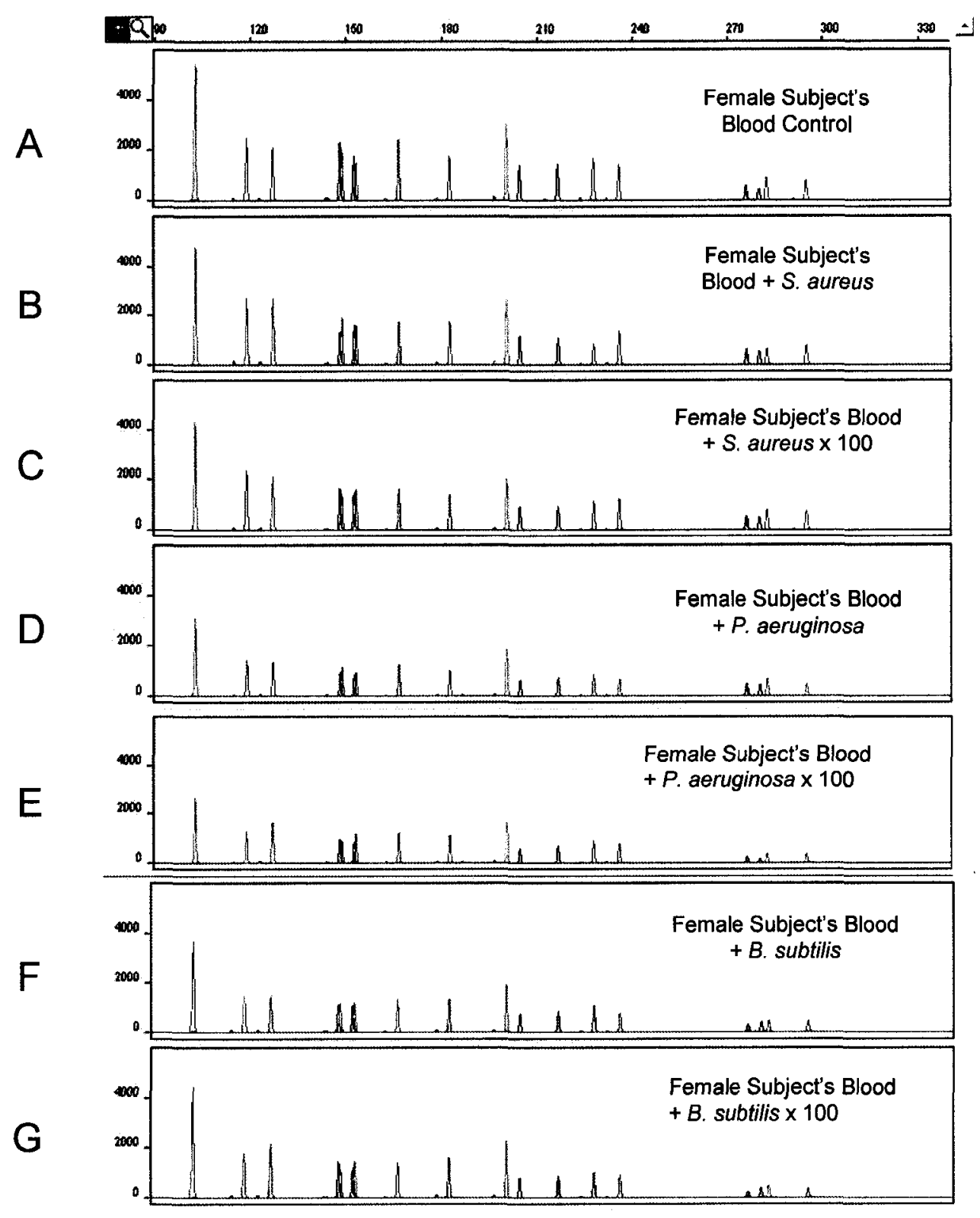

Figure 9 - Electropherogram STR profiles of DNA from Female Subject's blood contaminated with risk group 1 and risk group 2 bacteria. Sample types include Female Subject's blood control (Panel A), blood with $S$. aureus (Panel B), blood with concentrated amounts of $S$. aureus (Panel C), blood with $P$. aeruginosa (Panel D), blood with concentrated amounts of $P$. aeruginosa (Panel E), blood with B. subtilis (Panel F) and blood with concentrated amounts of B. subtilis (Panel G). Samples were extracted using Promega's DNA IQ System. Samples were treated with an overnight lysis at $56^{\circ} \mathrm{C}$ with a homemade Stain Extraction buffer with Pro. $\mathrm{K}$ and centrifuged with a $0.2 \mu \mathrm{m}$ filter after lysis. Each panel depicts the relative fluorescence intensity (Y axis) and the size estimate in bases (X axis). STR loci (left to right): Amelogenin (green), D3S1358 (blue), D5S818 (black), D8S1179 (green), vWA (blue), D13S317 (black), D21S11 (green), FGA (blue), D7S820 (black), D18S51 (green). 


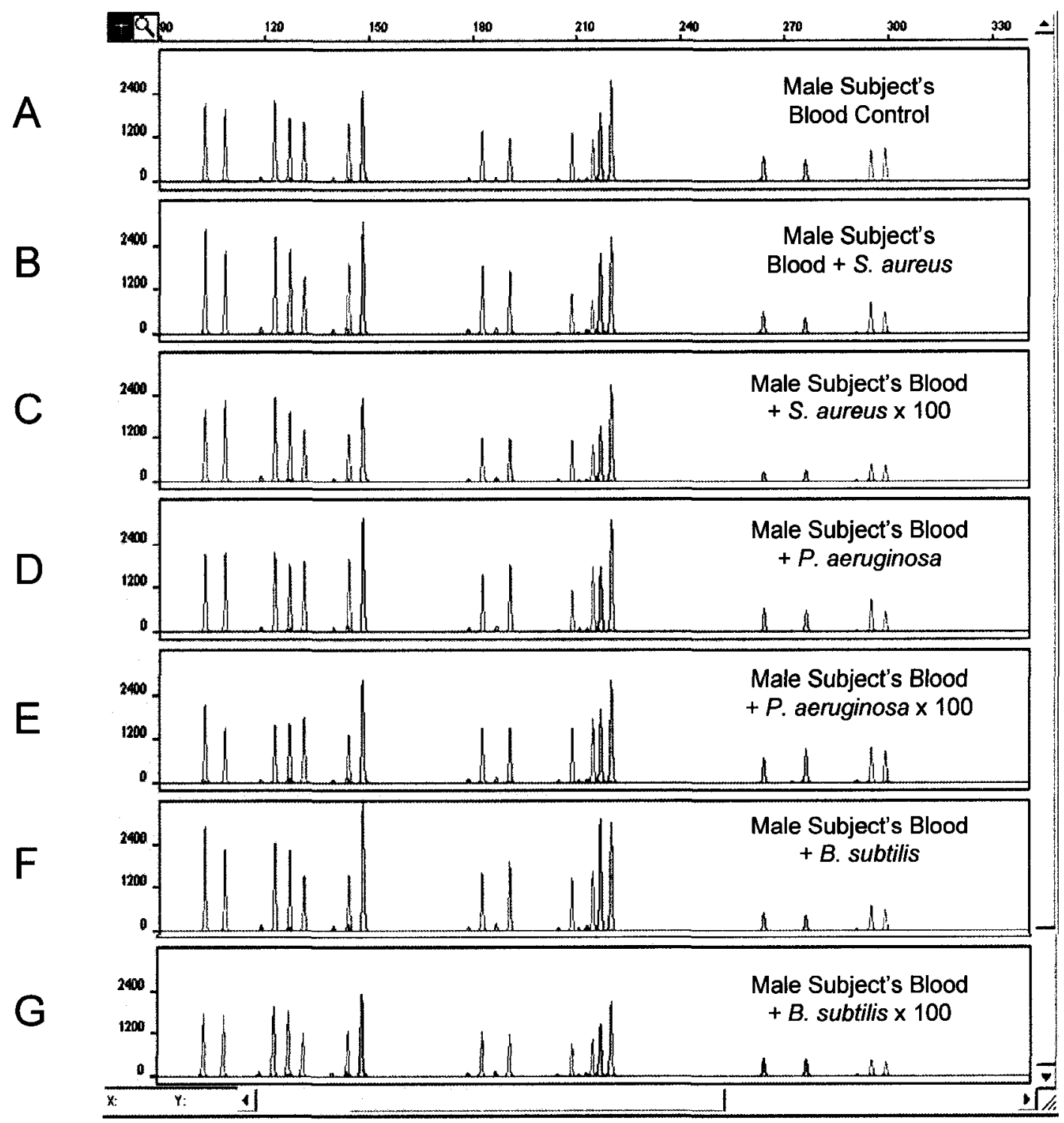

Figure 10 - Electropherogram STR profiles of DNA from Male Subject's blood contaminated with risk group 1 and 2 bacteria. Sample types include Male Subject's blood control (Panel A), blood with $S$. aureus (Panel B), blood with concentrated amounts of $S$. aureus (Panel C), blood with P. aeruginosa (Panel D), blood with concentrated amounts of $P$. aeruginosa (Panel E), blood with $B$. subtilis (Panel F) and blood with concentrated amounts of B. subtilis (Panel G). Samples were extracted using Promega's DNA IQ System. Samples were treated with an overnight lysis at $56^{\circ} \mathrm{C}$ with a homemade Stain Extraction buffer with Pro. K and centrifuged with a $0.2 \mu \mathrm{m}$ filter after lysis. Each panel depicts the relative fluorescence intensity ( $\mathrm{Y}$ axis) and the size estimate in bases (X axis). STR loci (left to right): Amelogenin (green), D3S1358 (blue), D5S818 (black), D8S1179 (green), vWA (blue), D13S317 (black), D21S11 (green), FGA (blue), D7S820 (black), D18S51 (green). 


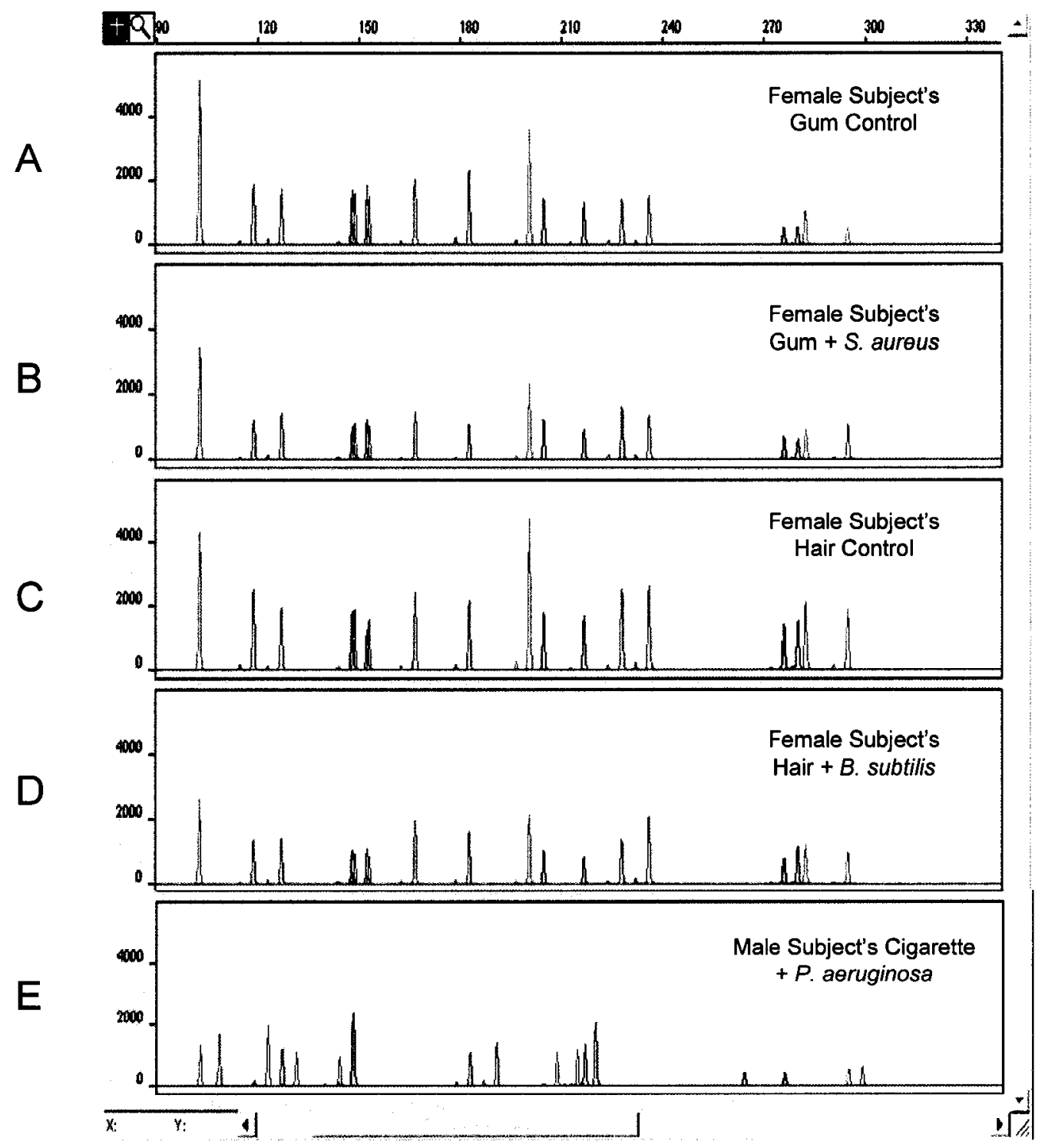

Figure 11 - Electropherogram STR profiles of DNA from various sample types contaminated with risk group 1 and 2 bacteria. Sample types include Female Subject's Gum control (Panel A), Female Subject's gum with $S$. aureus (Panel B), Female Subject's hair control (Panel C), Female Subject's hair with B. subtilis (Panel D) and Male Subject's cigarette with $P$. aeruginosa (Panel E). There were no results for the cigarette control since there were insufficient amounts of DNA. Samples were extracted using Promega's DNA IQ System. Samples were treated with an overnight lysis at $56^{\circ} \mathrm{C}$ with a homemade Stain Extraction buffer with Pro. $\mathrm{K}$ and centrifuged with a $0.2 \mu \mathrm{m}$ filter after lysis. Each panel depicts the relative fluorescence intensity ( $\mathrm{Y}$ axis) and the size estimate in bases (X axis). STR loci (left to right): Amelogenin (green), D3S1358 (blue), D5S818 (black), D8S1179 (green), vWA (blue), D13S317 (black), D21S11 (green), FGA (blue), D7S820 (black), D18S51 (green). 


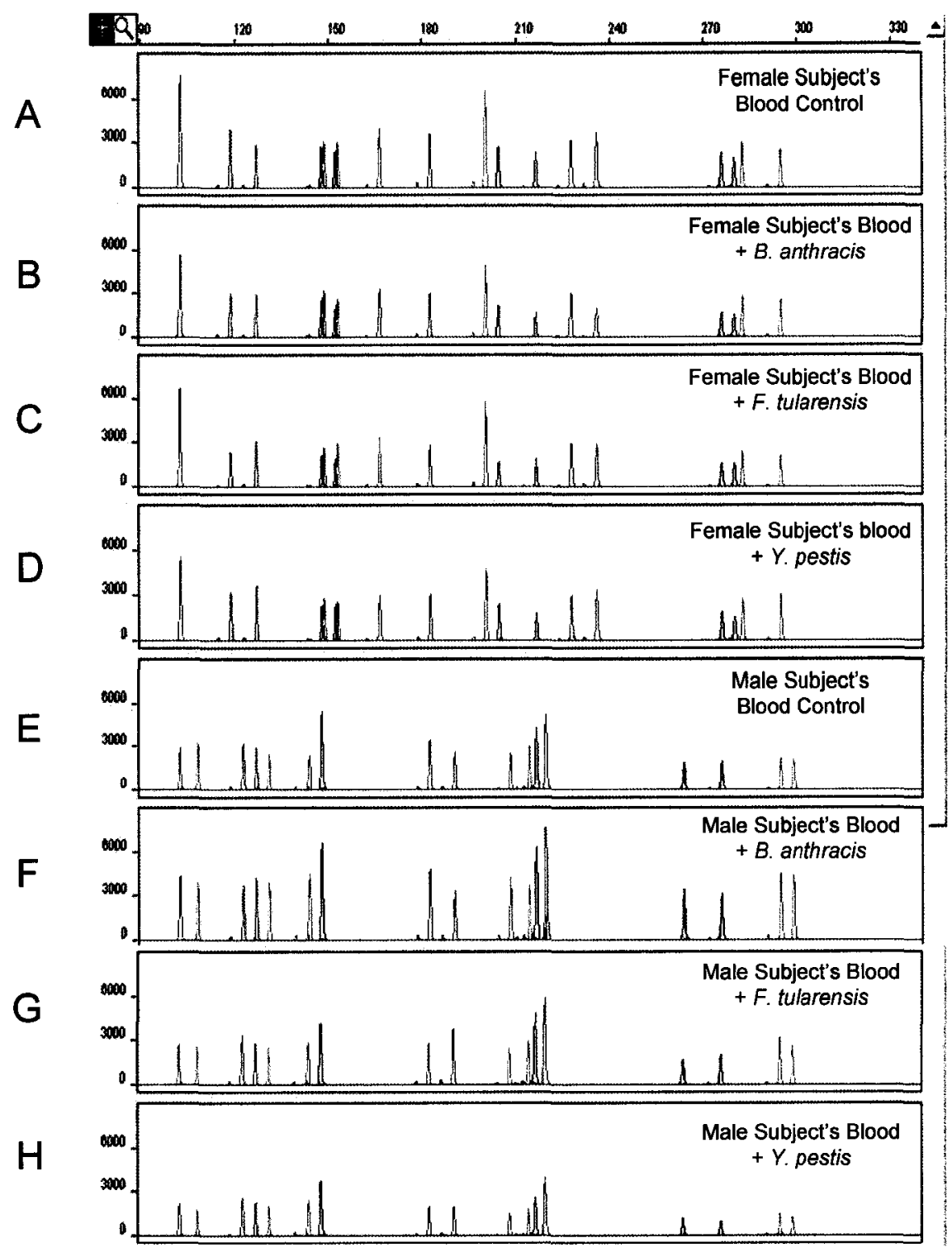

Figure 12 - Electropherogram STR profiles of DNA from human blood contaminated with risk group 3 bacteria. Sample types include Female Subject's blood control (Panel A), Female Subject's blood with B. anthracis (Panel B), Female Subject's blood with $F$. tularensis (Panel C), Female Subject's blood with $Y$. pestis (Panel D), Male Subject's blood control (Panel E), Male Subject's blood with B. anthracis (Panel F) Male Subject's blood with F. tularensis (Panel G) and Male Subject's blood with $Y$. pestis (Panel H). Samples were extracted using Promega's DNA IQ System. Samples were treated with an overnight lysis at $56^{\circ} \mathrm{C}$ with a homemade Stain Extraction buffer with Pro. $\mathrm{K}$ and centrifuged with a $0.2 \mu \mathrm{m}$ filter after elution. Each panel depicts the relative fluorescence intensity ( $\mathrm{Y}$ axis) and the size estimate in bases ( $\mathrm{X}$ axis). STR loci (left to right): Amelogenin (green), D3S1358 (blue), D5S818 (black), D8S1 179 (green), vWA (blue), D13S317 (black), D21S11 (green), FGA (blue), D7S820 (black), D18S51 (green). 
Table 27 - Ratio of STR D3/D18 Relative Fluorescent Units (RFU) to determine DNA degradation for samples from blood contaminated with risk group 1 and 2 bacteria

\begin{tabular}{|l|c|c|}
\hline \multicolumn{1}{|c|}{ Sample } & \multicolumn{2}{c|}{ Ratio of STR D3/D18 } \\
& RFU \\
\hline & Trial 1 & Trial 2 \\
\hline Female Subject's blood control & 2.6 & 13.8 \\
\hline Female Subject + S. aureus & 3.6 & 13.5 \\
\hline Female Subject + concentrated S. aureus & 2.8 & 15.1 \\
\hline Female Subject + P. aeruginosa & 2.3 & 8.2 \\
\hline Female Subject + concentrated $P$. aeruginosa & 3.6 & 16.2 \\
\hline Female Subject + B. subtilis & 3.1 & 5.6 \\
\hline Female Subject + concentrated B. subtilis & 4.4 & 28.5 \\
\hline
\end{tabular}


Table 28 - Ratio of STR D3/D18 Relative Fluorescent Units (RFU) to determine DNA degradation for samples from blood contaminated with risk group 1 and 2 bacteria

\begin{tabular}{|l|c|c|}
\hline \multicolumn{1}{|c|}{ Sample } & \multicolumn{2}{c|}{ Ratio of STR D3/D18RFU } \\
\hline & Trial 1 & Trial 2 \\
\hline Male Subject's blood control & 2.3 & 6.2 \\
\hline Male Subject + S. aureus & 3.5 & 15.6 \\
\hline Male Subject + concentrated S. aureus & 4.6 & 7.1 \\
\hline Male Subject + P. aeruginosa & 2.8 & $\mathrm{n} / \mathrm{a}$ \\
\hline Male Subject + concentrated P. aeruginosa & 1.7 & 6.0 \\
\hline Male Subject + B. subtilis & 3.6 & 4.3 \\
\hline Male Subject + concentrated B. subtilis & 4.3 & $\mathbf{8 . 1}$ \\
\hline
\end{tabular}


Table 29 - Ratio of STR D3/D18 Relative Fluorescent Units (RFU) to determine DNA degradation for samples from gum, hair and cigarettes contaminated with risk group 1 and 2 bacteria

\begin{tabular}{|l|c|}
\hline \multicolumn{1}{|c|}{ Sample } & Ratio of STR D3/D18 \\
& RFU \\
\hline Female Subject's gum control & 2.3 \\
\hline Female Subject's gum + S. aureus & 1.4 \\
\hline Female Subject's hair control & 1.1 \\
\hline Female Subject's hair + B. subtilis & 1.3 \\
\hline Male Subject's cigarette + P. aeruginosa & 2.6 \\
\hline
\end{tabular}


Table 30 - Ratio of STR D3/D18 Relative Fluorescent Units (RFU) to determine DNA degradation for samples from blood contaminated with risk group 3 bacteria

\begin{tabular}{|l|c|c|}
\hline \multicolumn{1}{|c|}{ Sample } & \multicolumn{2}{c|}{ Ratio of STR D3/D18RFU } \\
\hline & Trial 1 & Trial 2 \\
\hline Female Subject's blood control & 1.2 & 1.9 \\
\hline Female Subject's blood + B. anthracis spores & 1.1 & $\mathrm{n} / \mathrm{a}$ \\
\hline Female Subject's blood $+F$. tularensis & 0.9 & 1.5 \\
\hline Female Subject's blood $+Y$. pestis & 1.2 & 1.1 \\
\hline Male Subject's blood control & 1.4 & 4.0 \\
\hline Male Subject's blood + B. anthracis spores & 0.9 & 1.0 \\
\hline Male Subject's blood $+F$. tularensis & 1.0 & 1.3 \\
\hline Male Subject's blood $+Y$. pestis & 1.9 & $\mathrm{n} / \mathrm{a}$ \\
\hline
\end{tabular}




\section{DISCUSSION}

The anthrax letters of 2001 demonstrate that bioterrorism can severely compromise national security. Due to the real threat of bioterrorist attacks, government agencies, military, police, EMS, laboratories and hospitals must be prepared and have an emergency response plan in place. This emergency response plan should include procedures on how to detect, inactivate and decontaminate biothreat agents. Emergency response teams need to have a plan to decide what level of personal protection to use at the scene of the crime and how to collect evidence to identify the suspect. Not all bioterrorist attacks would be immediately noticeable, unless there was an explosion or advanced warning of the attack. Biological attacks are different from chemical attacks. Biological agents could go undetected since they are odourless and invisible when dispersed. It could be weeks before it was determined that a biological attack had occurred. It may take even longer before a connection is made between cases of illness and where the release of the agent may have occurred (Henderson, 1999).

The response plan should also include procedures for patient care, administration of antibiotics and vaccines and quarantine of patients with serious illnesses. Laboratories will need to be prepared to process hundreds of samples from patients showing similar signs and symptoms that may be due to biothreat agents. They will need to identify the organism as soon as possible so that the source of the infection can be determined and managed effectively. The public would need to be made aware of the situation without causing hysteria and unnecessary panic. Emergency rooms, family physicians and clinics 
would need to deal with a significant increase in patients showing up with possible symptoms, not all relating to the incident.

Bioterrorism is a crime and therefore evidence must be collected and analyzed. The problem addressed in this thesis is how to deal with human DNA evidence that is potentially contaminated with biothreat agents. More specifically, the problem is how to extract DNA and perform DNA analysis on a sample without endangering the lives of the forensic scientists. Forensic laboratories in Canada have limited access to containment level 3 facilities therefore high risk bacteria must be inactivated or removed before forensic analysis can take place. The non-destructive method proposed and evaluated in this thesis was to use a $0.2 \mu \mathrm{m}$ filter after DNA elution in order to retain any bacteria that were not lysed or removed by the DNA extraction procedure.

Three different Risk Group 3 biothreat agents were investigated: B. anthracis, $Y$. pestis and F. tularensis. These agents were chosen since they were accessible and they are considered probable agents that could be selected in a bioterrorist attack. Anthrax spores are hardy and can be made into a powder which is easy to aerosolize, $Y$. pestis has the capability of infecting thousands of people since it is transmissible from person to person and $F$. tularensis is highly infectious and requires as little as 10 organisms for infection. All three agents have the potential to cause terror and may result in a huge impact on the health system. In the case of a bioterrorist attack the agent doesn't necessarily need to kill hundreds, since just causing illness is enough to strain resources in areas such as law enforcement, hospitals and emergency response (Hawley \& Eitzen, 2001). 
Several different sources of DNA evidence were evaluated: blood, hair, cigarettes, chewing gum and trace DNA from gloves. Blood was the primary type of DNA used since the volume could be kept consistent. Although the actual amount of DNA within the volume of blood could differ between samples since it was not possible to control the number of white blood cells. A potential crime scene could involve the area of release of the organism or the area of manufacture of the organism. The suspect could leave a number of different items behind containing his or her DNA. If the evidence was found at the release site or the production site there could still be biothreat agents left behind that would contaminate the samples. Caution must be taken and proper personal protective equipment should be worn. Samples would need to be tested to determine the pathogen present and to identify the suspect. Therefore care must be taken while handling the samples.

It is important to develop a method of decontaminating the samples so that the integrity of the DNA from the biological is not compromised as well so that PCR methods can be used to identify and type the agent so that the health care facilities know what they are dealing with. It is also important to try to link the bacterial strain used to other known incidences or to link it to a certain laboratory or person involved.

\section{Research Objectives - Quality Control for Safety}

The first objective of this research project was to modify a current DNA extraction protocol in order to remove contaminating bacteria and to ensure that the modifications did not interfere with the integrity of the human DNA so that a human DNA profile could be obtained. These objectives were met. A $0.2 \mu \mathrm{m}$ filter step was introduced after the elution step during the DNA extraction procedure. The filter used 
was a Millipore Ultrafree ${ }^{\circledR}-\mathrm{MC}$ centrifugal filter unit which has a microporous filter unit with a $0.2 \mu \mathrm{m}$ low binding Durapore ${ }^{\circledR}$ Polyvinylidene Chloride (PVDC) membrane. Following elution from the magnetic resin the DNA was placed in the filter and centrifuged at $10,000 \mathrm{xg}$ for $2 \mathrm{~min}$. To ensure that the DNA no longer contained bacteria, half of each sample was cultured with appropriate media and incubated for two weeks. No bacterial growth was present on any of the samples for Risk Group 3 bacteria. For Risk Group 1 and 2 bacteria some samples had bacterial growth but they were possibly due to environmental contamination from the laboratory. To further demonstrate that the filters were capable of retaining bacteria, 100 bacterial suspensions from Risk Group 3 were filtered, plated on media and incubated. Once again there was no growth of bacteria on any of the 100 samples tested. Another 75 samples from risk group 2 and 3 bacteria were evaluated and 74 out of 75 samples showed no growth. One B. subtilis sample had growth after filtration although this may have been due to environmental contamination since this is an organism that is frequently used in the lab. Another possible explanation for bacterial contamination of this sample is leakage of the filter.

Integrity of the $0.2 \mu \mathrm{m}$ filter is, indeed, of concern for proper implementation of the method developed in this thesis. During the testing of Risk Group 1 and 2 bacteria there was a box of filters that was found to be defective. The filters appeared to be torn or disintegrated after the sample was centrifuged. Water was placed in the top of the filter and it leaked through without having to be centrifuged. Samples processed with these filters were found to have bacterial growth after incubation. This was an important finding; it demonstrated that while the filters were effective in removing unlysed bacteria from the samples, it is still important to establish quality control procedures. The filters 
should be examined to ensure that they are not damaged and filter integrity should be tested for each lot to ensure that they are working effectively by culturing filtrates on appropriate growth media.

\section{Research Objectives - Quality Control for DNA Integrity}

The second objective of this thesis was to ensure that the integrity of the human DNA was not compromised and to ensure that the bacterial DNA did not interfere with the human DNA profiling. DNA samples from blood contaminated with Risk Group 1 and 2 bacteria were found to have DNA degradation although it cannot be concluded that the bacteria were responsible since the control samples without bacteria showed similar and, in some cases, more DNA degradation. DNA samples from blood contaminated with Risk Group 3 bacteria had very little or no DNA degradation. Therefore it does not appear that the bacteria have a significant effect on the integrity of the human DNA. Nor does the presence of contaminating bacterial DNA interfere with the DNA profiling. It is important to remember that the human DNA was not exposed to the bacteria for an extended period of time and references do suggest bacterial enzymes can degrade DNA (Bender et. al., 2004). The possibility that prolonged exposure to bacteria would reduce the quality of forensic evidence requires further study.

It was observed that samples contaminated with Risk Group 1 and 2 bacteria were of poorer quality, being slightly more degraded than those contaminated with Risk Group 3 bacteria. The difference between the Risk Group 1 and 2, and Risk Group 3 samples is possibly due to where in the extraction procedure the filtration step was introduced. For the Risk Group 1 and 2 samples the filtration step was introduced right after lysis, when the DNA is still bound to proteins, this may cause the DNA to tear while passing through 
the $0.2 \mu \mathrm{m}$ filter. For the Risk Group 3 samples the filtration step was performed after the elution step as a final step in the DNA extraction. At this stage the DNA has been purified and may pass through the $0.2 \mu \mathrm{m}$ filter more easily without tearing or shearing.

In the event of a bioterrorist event or accidental release, this modified DNA extraction procedure could be used by emergency response personnel in the field or by laboratory analysts in a containment level 3 laboratory. The procedure illustrates how to remove contaminating bacteria and how to follow quality control procedures by testing each sample for bacterial growth. The procedure also shows how to safely remove the sample from the CL3 lab or from the contamination site in order to transport the sample to a forensic laboratory for further testing. This technique can also be used for routine applications in a CL3 lab. Laboratory technicians could extract DNA from RG3 bacteria and filter the DNA so that PCR or other testing could be performed in a standard lab. It is a quick and easy way to remove bacteria from DNA samples.

\section{Discussion of results}

\section{Effect of heat on bacteria:}

Lysis buffer and heat are probably sufficient to inactivate viruses and vegetative bacteria. However such procedures may not always lyse every bacteria cell. For example, if the sample was placed inside a microcentrifuge tube and the sample touched the side of the tube, some cells may not be heated to a temperature required for inactivation. This may be was especially true if a heating block was used. Using a water bath would likely ameliorate the problem since it provides a more uniform heat, although it may not be effective in killing all bacteria, especially bacteria that tend to form clumps. If spores are 
present, as in the case of anthrax, heating to $56^{\circ} \mathrm{C}$ will not be effective. Some bacterial spores are very resistant to inactivation by heat and radiation (Dang et. al., 2001).

For vegetative bacteria (S. aureus), heating at $56^{\circ} \mathrm{C}$ or $95^{\circ} \mathrm{C}$ combined with lysis buffer was sufficient to kill all bacteria in my experiments. The results for $B$. subtilis indicated that higher temperatures are required to effectively kill spore forming bacteria. Due to the different types of samples to be analyzed such as cigarettes and gum that become difficult to work with at high temperatures, changes were made to Promega's original DNA extraction procedure by the RCMP and the routine temperature used is $56^{\circ} \mathrm{C}$. Therefore at this temperature it is important to note that spore forming bacteria are not effectively killed. By passing samples through a $0.2 \mu \mathrm{m}$ filter, regardless of extraction temperatures used, bacterial contamination of the resulting DNA samples is unlikely.

Bacterial spores are very hardy and can survive in harsh environments. Vegetative bacterial cells slow down their metabolism and become highly structured during sporulation. B. anthracis spores contain an exosporium which is a loose outer layer produced by the mother cell (Liu et. al., 2004). The exosporium contains few protein species and is highly glycosylated although the function of it is still being researched. This additional layer is not found in B. subtilis (Lai et. al., 2003). B. subtilis contains a structured outer layer of protein called the coat which is a tough protective shell. The coat of $B$. anthracis is found to be thinner than that of $B$. subtilis. This layer is critical for the survival and resistance of the spore and it regulates the penetration of germination cues and the exclusion of toxins (Lai et. al., 2003; Kim et. al., 2004). Other layers are the lipid membrane and layers of cross linking peptidoglycan including the cortex which 
maintains low levels of water in the core. These structural differences allow for spores to survive and resist treatments such as heating or some chemical disinfection (Driks, 2004).

\section{Varying concentrations of blood quantified with PicoGreen:}

PicoGreen was used to quantify DNA from blood contaminated with $S$. aureus. PicoGreen is a non-specific fluorescent stain that binds to any double stranded DNA. It does not distinguish between human and bacterial DNA. There was no apparent increase in DNA concentration when bacterial DNA was added to human blood samples prior to the DNA extraction procedure. There was also no apparent increase in DNA when there were larger volumes of blood used. This could imply that in my experiments the amount of DNA was enough to saturate the resin. Samples were quantified in duplicate although one sample was diluted in half and when the dilution factor was added in and the concentration was compared to the undiluted sample the two were not always similar. PicoGreen was very easy to use with minimal steps and minimal room for error. When compared to other methods of quantification such as Promega AluQuant or Roche LightCycler with SYBR green dye the concentrations were lower by approximately 10 fold for most samples.

\section{Quantification of DNA after filtration using PicoGreen:}

Due to variations in amounts of DNA, it could not be concluded that filtration had an effect on DNA yield. Rinsing after filtering was found to increase the amount of DNA recovered in half of the samples. It was interesting to note that performing lysis at $95^{\circ} \mathrm{C}$ for $30 \mathrm{~min}$ gave higher yields of DNA than lysis at $56^{\circ} \mathrm{C}$ overnight. When reviewing the results it is also important to note that although the same volume of blood was used the 
amount of white blood cells containing DNA can vary between samples. Results from the PCR amplification using short tandem repeats D18 and D3 showed that the DNA was of sufficient quality and quantity for forensic profiling. The STRs always amplified at a crossing point slightly above the human DNA standard and always well below the blank and the bacteria only samples. This indicated that the DNA extractions could be sent to the RCMP for further analysis. The blank samples and bacterial samples did amplify, although much later in the PCR run. This was because SYBR green is a non-specific DNA stain that will bind to any double stranded DNA including primer-dimers and there may have been non-specific reactions. Agarose gel electrophoresis indicated that the amplicons from blood were of the correct length for each STR whereas amplicons from the blank samples and bacteria DNA samples were not the correct size.

\section{DNA Extraction and Quantification of varying amounts of blood with AluQuant:}

DNA from samples with varying concentrations of human blood was extracted to determine if there was saturation of the magnetic resin. The magnetic resin in the Promega DNA IQ system has the capacity of binding $100 \mathrm{ng}$ of DNA when $7 \mu 1$ of resin is used. Therefore an increase in resin to $12 \mu$ l should theoretically bind approximately 170 ng of DNA. It appeared the resin was saturated when between $1 \mu l$ and $50 \mu l$ of blood was used since volumes of blood greater than $50 \mu 1$ did not give an increase in DNA recovered. Samples that were filtered gave a decreased amount of DNA, although there was still a large amount of DNA recovered, at least $25 \mathrm{ng}$ for $1 \mu \mathrm{l}$ of blood, which is more than enough for DNA typing where only 1ng of DNA is needed. The addition of a rinsing step could increase the yield although it may affect the integrity of the filter. The small 
loss in yield of DNA to the filter matrix is the price for rendering the sample safe for forensic analysis.

Extraction, quantification and amplification of DNA from blood contaminated with

\section{S. aureus at $56^{\circ} \mathrm{C}$ overnight}

These results indicated that the Promega AluQuant Human DNA Quantitation kit gave DNA concentrations that were not consistent and not reproducible. Not all samples could be quantified due to problems with the procedure. Although the probes were human specific, samples containing bacteria only still yielded quantifiable results, although these were low compared to the human DNA samples. In order to process a larger number of samples in less time, the analysis of human STRs was performed in one PCR reaction with primers for both D18 and D3 in the same master mix. Again the samples with human DNA amplified at a crossing point $(\mathrm{Cp})$ similar to the human standard and well below the $\mathrm{Cp}$ of the bacteria only DNA or the blank (water). The gel indicated that the STR amplicons are still amplifying and they are the appropriate length. Gel electrophoresis was used as a quick analysis to determine that the samples were of sufficient quality to be sent to the RCMP for DNA typing.

\section{Extraction, quantification and amplification of blood contaminated with risk group}

\section{1 and 2 vegetative bacteria}

Samples were generated for DNA typing by the RCMP forensic specialists. Three different methods of DNA quantification were used to compare the results and also to ensure that there was enough DNA to be amplified and typed. The three different methods generally all gave similar results. For blood with $S$. aureus Promega AluQuant quantitation kit gave higher DNA concentrations. There was no indication that there was 
more DNA when bacteria were added, which was predicted since all three methods were human DNA specific. Promega AluQuant only gave a signal for $P$. aeruginosa and the concentration was $1.26 \mathrm{ng}$. Roche SYBR Green dye gave signals for all bacteria, although they were all below 1ng. The Quantifiler kit was the most human specific procedure and did not give any results for bacteria.

\section{DNA Extraction, Quantification and Amplification of various sample types}

Human DNA could be extracted from various sample types found at a crime scene. These could include samples of human hair, skin, saliva, or blood, directly from subjects or transferred by subjects to other surfaces. To determine the ability to extract and recover human DNA from such samples, buccal swabs, human hair, Styrofoam cups, chewing gum, and pencils were employed. Buccal swabs and hair are both non-invasive means of obtaining DNA and were found to have large amounts of DNA ( $>300 \mathrm{ng}$ for buccal swabs and $>50 \mathrm{ng}$ for hair). The hair that was used contained the root which is a great source of DNA, although not all hair found at a crime scene will have the root, especially if it is shed and not pulled out. Therefore it may not always contain large amounts of useable DNA. Saliva and epithelial cells from gum and Styrofoam cups are also potential sources of DNA and can give enough DNA for DNA typing. Cigarettes gave variable amounts of DNA and in most cases not enough DNA was present for analysis. This may be due to the fact that one of the donors is a non-smoker and may have left less saliva or epithelial cells on the paper. There may have also been problems with the filter paper, it absorbed most of the lysis buffer and may have interfered with the lysis procedure. Fingerprints and trace amounts of skin cells from handling a pencil gave very little DNA which was not sufficient for DNA typing. 


\section{Extraction, quantification and amplification of gum, hair and cigarettes contaminated with risk group 1 and 2 vegetative bacteria}

DNA from gum and hair contaminated with bacteria had sufficient amounts of amplifiable human DNA. Again DNA from cigarettes was variable and not all samples could be used for DNA typing. Samples contaminated with $P$. aeruginosa and DNA from just $P$. aeruginosa was much higher in DNA concentration than any other bacteria. Results from the RCMP for $P$. aeruginosa did not show any non-specific reactions and no DNA was detected, although human samples with $P$. aeruginosa did have higher amounts of DNA for some samples. There may have been contamination of the bacterial stock that may contribute to these high amounts of human DNA.

\section{Effect of filtration on DNA yield:}

Experiments were run to determine if there was a decrease in DNA yield when a $0.2 \mu \mathrm{m}$ filter was used to filter DNA after lysis. Five samples of blood were filtered with a $0.2 \mu \mathrm{m}$ filter and five were not filtered, only centrifuged. Conclusions cannot be drawn as to whether or not there was a decrease in DNA since some samples that were filtered had less DNA and others had more overall. The average concentration was approximately the same. In all cases there was more than enough DNA present for analysis. Melting points for STR D18 and D3 were similar among samples and were within $1^{\circ} \mathrm{C}$.

Extraction/Amplification/Quantification of blood filtered after lysis vs. after elution:

DNA that was filtered after the elution step was found to have a slightly higher yield than DNA filtered after the lysis step, although there were large variations in amount of DNA between samples. DNA after lysis could have been still attached to proteins and may not have been washed or purified. The DNA that was still attached may 
have become trapped in the filter resulting in a decrease in yield. DNA after elution was purified and could potentially have passed through the $0.2 \mu \mathrm{m}$ filter pores more easily.

\section{DNA Amplification and Quantification of human blood contaminated with Risk}

\section{Group 3 bacteria}

For safety and quality control purposes, all DNA extractions were tested for growth before the samples could leave the CL3 laboratory. B. anthracis spores were found retained in the filter when the filters were tested for growth after DNA extractions were filtered through them. The spores were not fully lysed from the lysis buffer or heat and were still found in the DNA after the entire DNA extraction procedure. This reinforces the need to filter all samples before working with them outside a CL3 laboratory. It is practice in some laboratories to extract DNA from bacteria and analyze the samples in a lesser containment laboratory without filtering. It is important to wait at least 1 week for the results for bacterial growth before working with the samples. This was not the case for a laboratory with the National Microbiology Laboratory where many lab workers could have become infected in a recent incident (Winnipeg Free Press, 2007). The samples were used right away without waiting for the quality control results and one of the samples was found to be positive for growth. Employees of the laboratory were subjected to antibiotic therapy. Fortunately it was found to be environmental contamination and not the organism they were working with but it demonstrates the need to follow proper quality control procedures that are necessary for the safety of the operator.

All samples had a large amount of DNA, more than samples with RG1 and RG2 bacteria. This may be due to the time of filtration, samples with RG3 bacteria were 
filtered after elution which could have increased DNA yield. All samples were amplifiable and had melting points specific for STRs D18 and D3. Some samples only had a high melting peak but not one for the lower temperature. The larger amplicon, D18 should have the higher melting point and the smaller amplicon, D3 should have the lower melting point. This was determined in previous experiments when STRs were analyzed separately. If DNA was degraded then the first STR that would be broken up would be the larger one, D18, but this was not seen in the results. The reason for no melting peak could be due to unfavourable PCR conditions. The temperature and time for primer annealing may not have been favourable or there may have been competition between the two primers for dNTPs, Taq polymerase or $\mathrm{MgCl}$. There may have also been more of one primer in the reactions compared to other reactions.

In some of the experiments DNA from bacteria only, specifically $Y$. pestis and F. tularensis amplified even though the primers are designed to amplify human STRs. There was also a shift in melting point for samples that contained $Y$. pestis. This may be due to non-specific binding of the primers due to non-optimal annealing temperatures for both sets of primers, or due to primer dimmers or non-specific binding of the SYBR Green dye.

\section{Short Tandem Repeat Analysis:}

The DNA from blood contaminated with RG1 and RG2 showed varying degrees of degradation, although a DNA profile was still obtained for all but one sample. DNA degradation was determined by comparing the relative fluorescence intensities of the smallest STR (D3) and the largest STR (D18). If degradation was present there would be an off balance between the two and the larger STR would have a lower intensity. When 
DNA degradation occurs it is the larger STRs that are fragmented into smaller pieces first (Butler et. al., 2003). All samples showed some degradation, the ones with the least amount had a 2 fold drop in intensity (Male donor DNA with concentrated $P$. aeruginosa) and the one sample with the most degradation had a 29 fold difference (Female donor DNA with concentrated amounts of B. subtilis). It cannot be concluded that the bacteria had an effect on DNA degradation since the control samples, containing no bacteria, showed just as much or more degradation than the samples containing bacteria. It should be noted, however, that samples that were older had more degradation. This could be due an increase storage time, although this was only increased by one month. It could also be due to the operator's familiarity with the technique, which could have improved with time. The blood used was never kept for longer than 1 week, therefore there shouldn't be a difference in degradation due to the age of the blood. Even though there was degradation present, 33 out of 36 samples yielded a full DNA profile, 2 had partial profiles (both female donor's control DNA) and 1 had no profile (Male blood with $P$. aeruginosa). The problematic samples were concentrated and re-run and the ones with the partial profiles worked and all loci could be typed. The one that previously yielded no result gave a partial profile after concentration.

A few samples from each type of DNA evidence were selected to be analyzed. Again the results indicated that there was DNA degradation from cigarette, gum and hair samples although useable DNA profiles were still generated. DNA from hair gave the best results with little degradation. For most of the cigarette samples there were insufficient quantities of DNA for DNA typing. There was also insufficient DNA from the inside of latex gloves. This may be because the donor was a non-shedder. 
DNA from blood contaminated with RG3 showed little or no DNA degradation.

The only samples that showed slight degradation were female donor's control DNA, male donor's control DNA and male donor's DNA with $Y$. pestis. There was a change to the DNA extraction protocol and the filtration step was switched to after DNA elution instead of lysis so that no additional bacteria were introduced into the sample during the DNA extraction process. Filtration after elution proves to be beneficial not only for safety reasons but also for DNA integrity.

\section{Biothreat Screening for Risk Group 3 Bacteria:}

Results from the biothreat screening kit demonstrated the potential dual use of the samples. Not only can the human DNA, of interest to the forensic scientist, be extracted from the evidence for human DNA typing, but also the bacterial DNA from the contaminating biothreat agent can be used to detect, identify and even type the bacterial pathogen. The bacterial DNA was not compromised and there was enough DNA to give positive reactions for the type of bacteria being analysed. If other methods of bacterial inactivation such as chemical, autoclaving or irradiation were used to decontaminate the human samples, the bacterial DNA may not have been usable for bacterial detection. Autoclaving anthrax spores at $121^{\circ} \mathrm{C}$ for $45 \mathrm{~min}$ still gives DNA that can be detected using PCR although there is a decrease in signal (Fasanella et. al., 2003). This may not affect the bacterial DNA but it may be problematic for human DNA. The loci used for bacterial detection may be unaffected but the longer STRs used in human testing may be more susceptible to DNA degradation. The use of a $0.2 \mu \mathrm{m}$ filter is therefore a nondestructive method that was shown in this study to preserve both the human DNA and the bacterial DNA. 


\section{Methods of Decontaminating Samples}

It is important that the methods used to inactivate the bacterial organism do not affect the human DNA present. Chemicals, autoclaving and using gamma irradiation are means of decontaminating samples but the effect that these methods have on the integrity of the human DNA and the potential for obtaining a human DNA profile must be examined.

Chemicals can be used to decontaminate samples or areas that have been contaminated with biothreat agents. CASCAD and MDF LSA-100 are chemical decontamination agents that have been tested on blood stain samples. It was discovered that human DNA profiles cannot be obtained from blood samples that have been decontaminated with these agents (Wilkinson et. al., 2007).

The US Postal Service is currently using electron beam irradiation to sterilize mail that could potentially contain biothreat agents. A study was performed to investigate the effect that the electron beam irradiation has on human DNA. The study found that irradiated samples had a lower DNA yield and longer STRs were compromised and had decreased detection (Castle et al., 2003). This study is also important because it indicates whether or not DNA can be obtained from envelops that have been used in a bioterrorist crime after they have been exposed to irradiation.

Another study examined saliva from envelops that were decontaminated using electron beam irradiation. The purpose of the study was to determine if the process also degrades human DNA and whether or not the saliva could be used for DNA typing to identify the person responsible. Electron beam irradiation kills anthrax spores by causing DNA damage and breakage of chemical bonds. Since this occurs in bacterial cells it 
could be true for human cells as well. STR analysis was performed to determine if a genetic profile could be obtained from decontaminated samples and it was found that although there was DNA degradation a full genetic profile for both nuclear and mitochondrial DNA was possible (Withrow et. al., 2003).

Microwave radiation is another method of inactivating bacterial spores. DNA that was released from bacterial spores was able to be amplified using PCR. This is valuable for food and pharmaceutical industries since they could use microwave radiation to treat their products and still be able to use the DNA to identify bacteria contaminating their products (Vaid \& Bishop, 1998). This method could possibly be used to decontaminate samples exposed to biothreat agents, although the effect on the human DNA would have to be investigated.

\section{Causes of DNA Degradation}

When a sample is degraded the DNA is fragmented into small pieces and the number of complete target fragments is reduced making it difficult to obtain amplicons from loci greater than 300-500bp (Chung et. al., 2004). A common way to determine if DNA damage is present is to determine if there is a decrease in amplification of larger STRs. The amount of template DNA to be amplified is lower with increasing DNA amplicon sizes (Deagle et. al., 2006). Comparing the smallest STR fluorescence (D3 for AmpFLSTR) and the largest STR fluorescence (D18 for AmpFLSTR) will provide information on DNA degradation. Samples with low level of degradation will show more of a balance between short and long STR products. Whereas highly degraded samples will yield less amplicons from larger STRs and may result in a partial profile (Withrow et. al., 2003). 
Many different environmental factors contribute to DNA degradation. They include heat, high humidity and UV light. UV light was used to generate degraded DNA samples for DNA typing experiments to investigate ways to perform analyses on degraded samples. Another method of degrading DNA is by using sonication and the enzyme DNAse I. It is also thought that contamination due to bacteria and fungi cause DNA degradation by affecting the physical, chemical and biochemical properties of DNA (Bender et. al., 2004). This was not seen in our research although the length of time that the bacteria were exposed to the sample may not have been sufficient to draw conclusions about whether or not the bacteria degraded the sample. Bacterial enzymes may have more of an effect with longer exposure. It is only known that the bacteria did not cause interference in the PCR reaction and it cannot be concluded that bacteria caused DNA degradation since the control samples were also degraded.

\section{DNA Quantification}

It is important to quantify DNA before performing short tandem repeat analysis. STR analysis only requires between $0.5-1$ ng of DNA. Too much DNA can result in offscale fluorescence whereas too little DNA can lead to allele dropout. It is much more cost efficient and less labour intensive to determine the amount needed before analysis so that samples don't need to be repeated (Kline et. al., 2005).

Three different methods of quantifying DNA were used in this research project. One method involved a dye called PicoGreen which is non-specific and will bind to any type of double stranded DNA. A fluorometer is used to measure the fluorescence; in this case the Roche LightCycler fluorometer was used to measure each sample separately. Another method used was Promega AluQuant DNA Quantification System with a 
Luminometer. This method used human probes in solution that bound to the DNA and caused a cascade of enzymatic reactions with the final product being adenosine triphosphate (ATP). Luciferase was added and it transformed the ATP into light which was detected with a luminometer. The last method used was quantitative real-time PCR. This method has proven to be the most successful and in some laboratories it has become the standard method of quantifying DNA (Swango et. al., 2006). The two kits used were LightCycler® FastStart DNA MasterPlus SYBR Green I and Applied Biosystems Quantifiler ${ }^{\mathrm{TM}}$. SYBR Green I is a fluorescent dye that binds to only double stranded DNA and can be detected using a fluorometer. Primers specific for human STRs D18 and D3 were used to amplify DNA and the samples were quantified during the PCR run. The crossing point, which is the cycle number where the increase in fluorescence crosses the background threshold, is used to quantify the DNA. Human genomic DNA was used as a standard and the concentration of DNA could be determined using a standard curve. The Quantifiler also uses real-time PCR technology along with a TaqMan® probe. Again the fluorescence is monitored as the DNA amplifies and the amount of DNA can be determined with the use of a standard curve.

A common method used by forensic labs before PCR became the standard was the slot-blot method. This was found to be too time consuming and it did not prove to work well for degraded or contaminated samples. Quantitative PCR can amplify as little as a single copy of DNA and can quantify specific sequences of DNA, such as human specific regions. The range of detection for quantitative PCR is between $30 \mathrm{pg}$ to $30 \mathrm{ng}$. It is a much more simple method that is time saving and can be automated (Swango et. al., 2006). 
The different methods of quantifying DNA gave variable results. They all differed in their simplicity and reproducibility. PicoGreen was easy to use although it was not useful in determining the amount of human DNA since it was not human specific. Promega's AluQuant had multiple steps with different incubation steps and many sample transfers. The multiple steps lead to many errors and less precision. Quantitative real time PCR was less hands on and didn't involve any incubation times or many sample transfers. The results were much more reliable and consistent. One of the problems with the different kits was that there were different human standards. There should be a universal standard reference sample that all laboratories should use so that the results can be compared to one another.

Not every laboratory uses the same method for quantifying DNA or the same standard reference material. Therefore the National Institute of Standards and Technology (NIST) did an inter-laboratory study to determine the variability in the methods of DNA Quantitation. It has been found that the accuracy of the quantification can have an effect on the DNA typing. It was also discovered that the quantification results did vary from lab to lab and also between methods. This study will also be used to develop a NIST Standard Reference Material for human DNA quantification (Kline et. al., 2003, Kline et. al., 2005).

\section{Bacterial Detection and Identification}

Not only is it important to identify the suspect in the case of a bioterrorist attack but it is also important to identify the causative agent. This is necessary so that the physicians and hospitals know what they are dealing with and can give the appropriate treatment to patients but it can also be used to track the source of the bacteria and link it 
to a person or organization. Therefore it is also important that the method of inactivation of bacteria does not have an effect on the capability of detecting and identifying the bacterial agent. It has been found that using irradiation to inactivate $B$. anthracis spores can lead to a decrease in enzyme linked immunosorbent assay (ELISA) fluorescence. Spores that were autoclaved also showed a decrease when certain antibodies were used. This suggests that method inactivation also inactivates epitopes that are used for detection. Irradiation and autoclaving of spores also gave a decrease in fluorescence when PCR was used to amplify virulence genes capA and lef(Dang et. al., 2001). It is important to note that not only were the filtered DNA extractions used for human DNA profiling but they could also be used to identify the bacteria. Biothreat kits were used to amplify and detect specific virulence genes for B. anthracis, Y.pestis and F. tularensis. The filtration of the sample did not affect the detection of the biothreat agents, they still tested positive for the agent they were contaminated with and they amplified at a crossing point close to the positive sample.

A different type of investigation is performed when there is suspicion that a bioterrorist event has occurred. Microbial forensics involves identifying and molecular subtyping bacterial agents used in order to identify the source of the bacteria and possibly the suspect. Comparison of molecular subtypes of bacteria from samples to those in a database can help determine the strain and possibly the substrain used. During the investigation of the anthrax letters multilocus variable number of tandem repeats was used to determine that the genotype of the anthrax used was the same as the Ames strain which is used in research laboratories (Popovic \& Glass, 2001). 


\section{Future Applications}

Other work that could be completed is looking at how to adapt the DNA extraction procedure so that it could be used in the field. For field applications the DNA could be extracted within an isolator. This could be time consuming therefore a robotic system could be introduced. This would also reduce the operator's amount of time spent handling the organism and reduce the chance of infection. Risk-benefit analysis would be necessary to determine if it would be better to handle the samples in the field or to ship them to a CL3 for processing. Environmental bacteria could also be capable of degrading DNA. Therefore processing the samples in the field could result in less exposure time and could improve the odds of obtaining a human DNA profile.

The effect of the bacteria on the human samples after a prolonged contact time should also be examined. Human samples are known to degrade after a certain amount of time and this may be increased due to the presence of bacteria. Sample storage and shipping conditions would also have to be investigated. 


\section{CONCLUSION}

The use of a $0.2 \mu \mathrm{m}$ filter proved to be effective in removing contaminating bacteria from human DNA samples. Not only did it render the samples safe for human DNA analysis, it also did not appear to compromise the human DNA integrity. It was found to be a non-destructive method of eliminating RG3 bacteria. It could not be concluded that bacteria had an effect on DNA degradation. The modified DNA extraction procedure outlined in this research could be used for samples from a crime scene that are contaminated with biothreat bacteria or for routine work with RG3 samples so that the DNA could be analyzed in lesser containment laboratories.

When using a $0.2 \mu \mathrm{m}$ filter to remove any remaining bacteria there is a possibility that DNA will become trapped in the filter since there is a $5 \mu 1$ hold up volume. The loss of DNA to the filter could be minimized with a rinsing step although this could have an adverse effect on filter integrity. There is a trade off between yield and operator safety. However it was found that when filtration took place after DNA elution from resin there was a much higher DNA recovery and better quality DNA.

It is important to have quality control steps for safety and for DNA integrity. Every sample should be tested for growth before analysis to ensure that the procedure worked and that there were no problems with the filter. A quick analysis of DNA could be performed to ensure that the DNA is amplifiable and that STR amplicons are present so that time is not wasted analyzing samples with low amounts or degraded DNA. 


\section{LITERATURE CITED}

Alonso, A., Martin, P., Albarran, C., Garcia, P., Garcia, O., Fernandez de Simon, L., Garcia-Hirschfeld, J., Sancho, M., de la Rua, C. and Fernandez-Piqueras, J. (2004). Real-time PCR designs to estimate nuclear and mitochondrial DNA copy number in forensic and ancient DNA studies. Forensic Science International, 139: $141-149$.

Barber, M.D. and Parkin, B.H. (1996) Sequence analysis and allelic designation of the two short tandem repeat loci D18S51 and D8S1179. International. Journal of Legal Medicine, 109: 62-65.

Bell, C.A., Uhl, J.R., Hadfield, T.L., David, J.C., Meyer, R.F., Smith, T.F. and Cockerill III, F.R. (2002). Detection of Bacillus anthracis DNA by LightCycler PCR. Journal of Clinical Microbiology, 40(8): 2897-2902.

Bender, K., Farfan, M.J. and Schneider, P.M. (2004). Preparation of degraded human DNA under controlled conditions. Forensic Science International, 139: 135-140.

Butler, J.M., Devaney, J.M, Marino, M.A. and Vallone, P.M. (2001). Quality control of PCR primers used in multiplex STR amplification reactions. Forensic Science International, 119: 87-96.

Butler, J.M. (2005) Forensic DNA Typing: Biology, Technology, and Genetics of STR Markers $2^{\text {nd }}$ Ed. Elsevier, London, UK.

Castle, P.E., Garcia-Closas, M., Franklin, T., Chanock, S., Puri, V., Welch, R., Rothman, N. and Vaught, J. (2003). Effects of Electron-Beam Irradiation on Buccal-Cell DNA. American Journal of Human Genetics, 73: 646-651.

Centre for Disease Control and Prevention (2007). Bioterrorism Agents/Diseases. Retrieved July 19, 2007. Website: http://www.bt.cdc.gov/Agent/agentlistcategory.asp

Chakraborty, R., Stivers, D.N., Su, B., Zhong, Y. and Budowle, B. (1999). The utility of short tandem repeat loci beyond human identification: Implications for development of new DNA typing systems. Electrophoresis, 20: 1682-1696.

Chung, D.T., Drabek, J., Opel, K.L., Butler, J.M. and McCord, B.R. (2004). A Study on the Effects of Degradation and template concentration on the amplification efficiency of the STR miniplex primer sets. Journal of Forensic Sciences, 49(4): 733- 740 .

Collier, R.J. and Young, J.A.T. (2003). Anthrax Toxin. Annual Review of Cell Division Biology, 19: 45-70. 
Cornelis, G.R., Boland, A., Boyd, A.P., Geuijen, C., Iriarte, M., Neyt, C., Sory, M.P. and Stainier, I. (1998). The Virulence Plasmid of Yersinia, an Antihost Genome. Microbiology and Molecular Biology Reviews, 62(4): 1315-1352.

Dang, J.L., Heroux, K., Kearney, J., Arasteh, A., Gostomski, M. and Emanuel, P.A. (2001). Bacillus Spore Inactivation Methods Affect Detection Assays. Applied and Environmental Microbiology, 67(8): 3665-3670.

Deagle, B.E., Eveson, J.P. and Jarman, S.N. (2006) Quantification of damage in DNA recovered from highly degraded samples - a case study on DNA in faeces. Frontiers in Zoology, 3: 11-21.

Demetrius, J.P. (2002) Biological and Chemical Bioterrorism Agents. Journal of the Association of Nurses in AIDS Care, 13(5): 57-64.

Dennis, D.T, Inglesby, T.V., Henderson, D.A., Bartlett, J.G., Ascher, M.S., Eitzen, E., Fine, A.D., Friedlander, A.M., Hauer, J., Layton, M., Lillibridge, S.R., McDade, J.E., Osterholm, M.T., O'Toole, T., Parker, G., Perl, T.M., Russel, P.K. and Tonat, K. (2001). Tularemia as a Biological Weapon. JAMA, 285(21): 2763-2773.

Driks, A. (2004). The Bacillus Spore Coat. The American Phytopathological Society, 94(11): 1249-1251.

Dull, P.M., Wilson, K.E., Kournikakis, B., Whitney, E.A.S., Boulet, C.A., Ho, J.Y.W., Ogston, J., Spence, M.R., Mckenzie, M.M., Phelan, M.A., Popovic, T. and Ashford, D. (2002). Bacillus anthracis Aerosilization Associated with a Contaminated Mail Sorting Machine. Emerging Infectious Diseases, 8(10): 10441047.

Ellis, J., Oyston, P.C.F., Green, M. and Titball, R.W. (2002) Tularemia. Clinical Microbiology Reviews, 15(4): 631-646.

Fasanella, A., Losito, S., Adone, R., Ciuchini, F., Trotta, T., Altamura, S.A., Chiocco, D. and Ippolito, G. (2003). PCR Assay to Detect Bacillus anthracis Spores in HeatTreated Specimens. Journal of Clinical Microbiology, 41(2): 896-899.

Firmani, M.A. and Broussard, L.A. (2003). Molecular diagnostic techniques for use in response to bioterrorism. Review of Molecular Diagnostics, 3(5): 605-616.

Frackman, S., Ekenberg, S., Hoffman, K., Krenke, B., Sprecher, C. and Storts, D. (2005). Plexor $^{\mathrm{TM}}$ Technology: A New Chemistry for Real Time PCR. Promega Notes, 90: $2-4$. 
Guidi-Rontani, C. and Mock, M. (2002). Macrophage interaction. Current Topics in Microbiology and Immunology, 271: 115-141.

Hawley, R.J. and Eitzen Jr, E.M. (2001). Biological Weapons - A primer for microbiologists. Annual Review Microbiology, 55: 235-253.

Henderson, D.A. (1999). The Looming Threat of Bioterrorism. Science, 283: 1279-1282. Jernigan, D.B., Raghunathan, P.L., Bell, B.P., Brechner, R., Bresnitz, E.A., Butler, J.C., Cetron, M., Cohen, M., Doyle, T., Fischer, M., Greene, C., Griffith, K.S., Guarner, J., Hadler, J.L., Hayslett, J.A., Meyer, R., Petersen, L.R., Phillips, M., Pinner, R., Popovic, T., Quinn, C.P., Reefhuis, J., Reissman, D., Rosenstein, N., Schuchat, A., Shieh, W-J., Siegal, L., Swerdlow, D.L., Tenover, F.C., Traeger, M., Ward, J.W., Weisfuse, I., Wiersma, S., Yeskey, K., Zaki, S., Ashford, D.A., Perkins, B.A., Ostroff, S., Hughes, J., Fleming, D., Koplan, J.P., Gerberding, J.L. and the National Anthrax Epidemiologic Investigation Team (2002). Investigation of Bioterrorism-Related Anthrax, United States 2001: Epidemiologic Findings. Emerging Infectious Diseases, 8(10): 1019-1028.

Kemp, C. (2001) Bioterrorism: Introduction and Major Agents. Journal of American Academy of Nurse Practitioners, 13(11): 483-491.

Kim, H-S., Sherman, D., Johnson, F. and Aronson, A.I. (2004). Characterization of a Major Bacillus anthracis Spore Coat Protein and Its Role in Spore Inactivation. Journal of Bacteriology, 186(8): 2413-2417.

Kline, M.C., Duewer, D.L., Redman, J.W. and Butler, J.M. (2003). NIST Mixed Stain Study 3: DNA Quantitation Accuracy and Its Influence on Short Tandem Repeat Multiplex Signal Intensity. Analytical Chemistry, 75: 2463-2469.

Kline, M.C., Duewer, D.L., Redman, J.W. and Butler, J.M. (2005). Results from the NIST 2004 DNA Quantitation Study. Journal of Forensic Sciences, 50(3): 571578 .

Kortepeter, M.G. and Parker, G.W. (1999). Potential Biological Weapons Threats. Emerging Infectious Diseases, 5(4): 523-527.

Lai, E-M., Phadke, N.D., Kachman, M.T., Giorno, R., Vazquez, S., Vazquez, J.A., Maddock, J.R. and Driks, A. (2003). Proteomic Analysis of the Spore Coats of Bacillus subtilis and Bacillus anthracis. Journal of Bacteriology, 185(4): 14431454.

Levi, K., Higham, J.L., Coates, D. and Hamlyn, P.F. (2003). Molecular detection of anthrax spores on animal fibres. Letters in Applied Microbiology, 36: 418-422. 
Li, H., Schmidt, L., Wei, M.-H., Hustad, T., Lerman, M.I., Zbar, B. and Tory, K. (1993) Three tetranucleotide polymorphisms for loci: D3S1352, D3S1358, D3S1359. Human Molecular Genetics 2: 1327.

Liu, H., Bergman, N.H., Thomason, B., Shallom, S., Hazen, A., Crossno, J., Rasko, D.A., Ravel, J., Read, T.D., Peterson, S.N., Yates III, J. and Hanna, P.C. (2004). Formation and Composition of the Bacillus anthracis Endospore. Journal of Bacteriology, 186(1): 164-178.

Mandrekar, M.N., Erickson, A.M., Kopp, K., Krenke, B.E., Mandrekar, P.V., Nelson, R., Peterson, K., Shultz, J., Terreba, A. and Westphal, N. (2001). Development of a Human DNA Quantitation System. Croatian Medical Journal, 42: 336-339.

Meselson, M., Guillemin, J., Hugh-Jones, M., Langmuir, A., Popova, I., Shelokov, A. and Yampolskaya. (1994). The Sverdlovsk Anthrax Outbreak of 1979. Science, 266: 1202-1208.

Pannucci, J., Okinaka, R.T., Williams, E., Sabin, R., Ticknor, L.O. and Kuske, C.R. (2002). DNA Sequence conservation between the Bacillus anthracis pXO2 plasmid and genomic sequence from closely related bacteria. BMC Genomics, 3: $34-41$.

Perez-Lezaun, A., Calafell, F., Mateu, E., Comas, D., Bosch, E. and Bertranpetit, J. (1997). Allele Frequencies for 20 Microsatellites in a Worldwide Population Survey. Human Heredity, 47: 189-196.

Popovic, T. and Glass, M (2003). Laboratory aspects of bioterrorism-related anthrax from identification to molecular subtyping to microbial forensics. Croatian Medical Journal, 44(3): 336-341.

Public Health Agency of Canada (2004). Laboratory Biosafety Guidelines, $3^{\text {rd }}$ Ed. Minister of Public Works and Government Services, Ottawa, Canada.

Restetin, V.P. and Regens, J.L. (2003) Simulation Modeling of Anthrax Spore Dispersion in a Bioterrorism Incident. Risk Analysis, 23(6): 1135-1145.

Roffey, R., Tegnell, A. and Elgh, F. (2002). Biological warfare in a historical perspective. Clinical Microbiological Infections, 8: 450-454.

Ruitberg, C.M., Reeder, D.J. and Butler, J.M. (2001). STRBase: a short tandem repeat DNA database for the human identity testing community. Nucleic Acids Research, 29(1): 320-322. 
Santic, M., Molmeret, M. and Kwaik, Y.A. (2005). Modulation of biogenesis of the Francisella Tularensis subsp. Novicida-containing phagosome in quiescent human macrophages and its maturation into a phagolysosome upon activation by IFN- $\gamma$. Cellular Microbiology, 7(7): 957-967.

Schmid, G. and Kaufmann, A. (2002). Anthrax in Europe: its epidemiology, clinical characteristics, and role in bioterrorism. European Society of Clinical Microbiology and Infectious Diseases, 8: 479-488.

Schumm, J.W. (1996). New Approaches to DNA Fingerprint Analysis. Notes Magazine, 58: $12-17$.

Sheeran, T.J. (2002). Bioterrorism,. In G. Bitton (ed), Encyclopedia of Environmental Microbiology, John Wiley and Sons, Inc., New York. p. 771-782

Smith, K.L., DeVos, V., Bryden, H., Price, L.B., Hugh-Jones, M.E. and Keim, P. (2000). Bacillus anthracis Diversity in Kruger National Park. Journal of Clinical Microbiology, 38(10): 3780-3784.

Swango, K.L, Timken, M.D, Chong, M.D. and Buoncristiani, M.R. (2006). A quantitative PCR assay for the assessment of DNA degradation in forensic samples. Forensic Science International, 158: 14-26.

Tamaki, K. and Jeffreys, A.J. (2005). Human tandem repeat sequences in forensic DNA typing. Legal Medicine, 7: 244-250.

Titball, R.W., Hill, J., Lawton, D.G. and Brown, K.A. (2003). Yersinia pestis and plague. Biochemical Society Transactions, 31(1): 104-107.

Turnbull, P.C.B. (1991). Anthrax vaccines: past, present and future. Vaccine, 9: 533-539.

Urquhart, A., Oldroyd, N.J., Kimpton, C.P. and Gill, P. (1995) Highly discriminating heptaplex short tandem repeat PCR system for forensic identification. BioTechniques, 18: 116-121.

Vaid, A. and Bishop, A.H. (1998). The destruction by microwave radiation of bacterial endospores and amplification of the released DNA. Journal of Applied Microbiology, 85: 115-122.

von Lubitz, D.K.J.E. (2004). Bioterrorism: field guide to disease identification and initial patient management. CRC Press.

Whitby, M., Ruff, T.A., Street, A.C. and Fenner, F.J. (2002). Biological agents as weapons 2: anthrax and plague. Medical Journal of Australia, 176: 605-608. 
Wilkinson, D.A., Sweet, D. and Fairley, D. (2007). Recovery of DNA from Exhibits Contaminated with Chemical Warfare Agents: A Preliminary Study of the Effect of Decontamination Agents and Chemical Warfare. Canadian Society of Forensic Science Journal, 40(1).

Winnipeg Free Press (2007). Bacteria contaminate microbiology laboratory. Aug 14, 2007. http://www.winnipegfreepress.com/local/story/3948338p-4560124c.html

Withrow, A.G., Sikorsky, J., Downs, J.C.U. and Fenger, T. (2003). Extraction and Analysis of Human Nuclear and Mitochondrial DNA from Electron Beam Irradiated Envelopes. Journal of Forensic Sciences, 48(6): 1-7. 